

\section{Poverty Alleviation and Forests in Vietnam}




\title{
Poverty Alleviation and Forests in Vietnam
}

\author{
By William D. Sunderlin \\ and Huynh Thu $\mathrm{Ba}^{2}$
}

${ }^{1}$ Center for International Forestry Research (CIFOR),

P.O. Box 6596 JKPWB, Jakarta, Indonesia. Email:w.sunderlin@cgiar.org

${ }^{2}$ School of Forestry and Environmental Studies,

Yale University, New Haven, Connecticut, USA. Email: thuba.huynh@yale.edu 
(c) 2005 by CIFOR

All rights reserved. Published in 2005

Printed by Subur Printing, Indonesia

Front cover photo by Christian Cossalter

Back cover photo by Koen Kusters

\section{ISBN 979-3361-57-3}

\section{National Library of Indonesia Cataloging -in-Publication Data}

Poverty Alleviation and Forests in Vietnam/

William D. Sunderlin and Huynh Thu Ba

p. $\mathrm{cm}$.

ISBN: 979-3361-57-3

1. Poverty 2. Forest resources 3. Forest management 4. Afforestation 5. Reviews

6. Rural development 7. Vietnam

\section{Published by}

Center for International Forestry Research

Mailing address: P.O. Box 6596 JKPWB, Jakarta 10065, Indonesia

Office address: Jalan CIFOR, Situ Gede, Sindang Barang,

Bogor Barat 16680, Indonesia

Tel.: +62 (251) 622622; Fax: +62 (251) 622100

E-mail: cifor@cgiar.org

Web site: http://www.cifor.cgiar.org 


\section{Contents}

Acknowledgements vii

Preface viii

Summary ix

List of acronyms and initials $\quad \mathrm{x}$

Introduction $\quad 1$

Poverty and poverty alleviation in Vietnam 1

Deforestation and forest cover restoration 3

What is the relationship between poverty alleviation and the forest sector? 4

The key questions posed in this literature review 6

Forests and poverty: An emerging field of global inquiry 7

Definitions of poverty, poverty alleviation, and forestbased poverty alleviation $\quad 7$

Modes of FBPA 9

Convergence or divergence of poverty alleviation and
forest condition

$\begin{array}{ll}\text { The approach of this review } & 12\end{array}$

The literature review 14

1. Conversion of forests to agriculture 14

2. Timber 24

3. Non-timber forest products (NTFPs) 32

4. Payments for environmental services $\quad 35$

5. Employment 41

6. Indirect benefits 43

New policies: Community forestry and benefit sharing $\quad 46$

Usefulness of forests for poverty alleviation in
Vietnam: A synthesis

Key research questions $\quad 53$

Summary and conclusions 56

Endnotes $\quad 58$

$\begin{array}{ll}\text { References } & 61\end{array}$ 
vi Contents

\section{Figures}

Figure 1. Incidence of poverty in Vietnam

Figure 2. Remaining areas of natural forest cover in Vietnam, 1996

Figure 3. Four-fold classification model of human well-being and forest cover

Table

Table 1. Answers to three key questions in connection with modes and sub-modes of forest-based poverty alleviation (FBPA) 


\section{Acknowledgements}

This publication was made possible in part through support provided by the Office of Agriculture, Bureau for Economic Growth, Agriculture and Trade, U.S. Agency for International Development through the Sustainable Agriculture and Natural Resources Management Collaborative Research Support Program (SANREM CRSP) under the terms of Cooperative Agreement Number PCE-A-00-98-00019-00. The opinions expressed herein are those of the authors and do not necessarily reflect the views of the U.S. Agency for International Development.

The Department for International Development (DFID) of the United Kingdom also provided substantial support for the realization of this publication.

We wish to thank the following reviewers for their generous comments on the draft report: Jill Blockhus, Bruce Campbell, Ross Hughes, Bao Huy, David Kaimowitz, Craig Leisher, and Thomas Sikor.

We are grateful as well for copy-editing done by Caroline Arthur, for the English to Vietnamese translation done by Vuong Thuc Tran, for expert guidance on the maps provided by Sonya Dewi and Atie Puntodewo, for guidance on the selection of photographs from Widya Prajanthi, and for the layout expertise of Gideon Suharyanto.

We alone are responsible for any errors or omissions in the published document. 


\section{Preface}

In this brief book, we have set out to answer some basic questions about the extent to which forest resources have served and will serve the goal of poverty alleviation in Vietnam. We have also asked to what extent the plans for massive reforestation in Vietnam are consistent with the government's goal to eliminate poverty.

It is not yet possible to do full justice to these questions because there has not yet been any primary, empirical research directed specifically at answering these questions. Nevertheless, we have attempted to answer these questions as best we could using the ample secondary literature that touches on these questions indirectly. We did so believing that there are some important points of information and lessons to be gathered and integrated, in spite of the considerable constraints on what the available information can tell us.

We are confident that we have assembled a useful body of knowledge that will offer guidance to policy makers, planners, researchers, students, and members of donor and aid organizations doing work in two realms: improvement of wellbeing, and improved conservation and management of Vietnam's forests.

Our fondest hope is that this book will be of use to our colleagues at the Forest Sector Support Program (FSSP), the Ministry of Agriculture and Rural Development (MARD), the Ministry of Planning and Investment (MPI), and other government institutions working on these issues. We hope that the information and ideas presented here can at least provoke thought, and that in the best case it can serve as a conceptual frame of reference on how to address these complex and vitally important issues.

William D. Sunderlin

Huynh Thu Ba

October 2004 


\section{Summary}

In Vietnam, as in many developing countries, there is an emerging interest in knowing to what extent and in what ways poverty alleviation can be achieved through use of forest resources, and to what extent poverty alleviation and maintenance or expansion of forest cover are compatible goals. This report seeks to summarize knowledge on this topic that can be obtained from the secondary literature. The methodological challenge is large because there exists a substantial literature on poverty alleviation in Vietnam, and separately a large literature on forestry, but there is little integration between the two. This review of the literature poses questions on: (1) the usefulness of forest resources in past poverty alleviation; (2) the usefulness of forest resources for future poverty alleviation; and (3) the degree of compatibility between poverty alleviation and plans for massive reforestation. The answers we provide to these questions are broad and lack precision, yet they serve as a crucial point of departure for addressing the linked issues of poverty alleviation and improved forest management. The review: (1) proposes additional research to fill the information void; (2) encourages the comparative method in this follow-up research; and (3) urges greater collaboration among government agencies responsible for poverty alleviation and forest management. A list of priority research questions is proposed. 


\section{List of acronyms and initials}

$\begin{array}{ll}\text { 5MHRP } & \text { Five Million Hectare Reforestation Project } \\ \text { ADB } & \text { Asian Development Bank } \\ \text { ASEAN } & \text { Association of Southeast Asian Nations } \\ \text { CIFOR } & \text { Center for International Forestry Research } \\ \text { CRES } & \text { Centre for Resource, Environment Studies in Vietnam } \\ \text { DFID } & \text { Department for International Development } \\ \text { FAO } & \text { Food and Agriculture Organization of the United Nations } \\ \text { FBPA } & \text { forest-based poverty alleviation } \\ \text { FD } & \text { Forest Department } \\ \text { FLA } & \text { Forest Land Allocation program } \\ \text { FPC } & \text { Forest Protection Contract } \\ \text { FPD } & \text { Forest Protection Department } \\ \text { GDP } & \text { gross domestic product } \\ \text { GSO } & \text { General Statistics Office } \\ \text { ICDP } & \text { Integrated Conservation and Development Project } \\ \text { MARD } & \text { Ministry of Agriculture and Rural Development } \\ \text { MOLISA } & \text { Ministry of Labor, Invalids and Social Affairs } \\ \text { MPI } & \text { Ministry for Planning and Investment } \\ \text { NEZ } & \text { New Economic Zones } \\ \text { NTFP } & \text { non-timber forest product } \\ \text { PAM } & \text { Programme Alimentaire Mondial (World Food Programme) } \\ \text { SAM } & \text { social accounting matrix } \\ \text { SANREM-CRSP } & \text { Sustainable Agriculture and Natural Resource Management, } \\ \text { SFDP } & \text { Collaborative Research Support Program } \\ \text { SFE } & \text { Social Forestry Development Program } \\ \text { USAID } & \text { State Forest Enterprise } \\ \text { VHLSS } & \text { United States Agency for International Development } \\ \text { VLSS } & \text { Vietnam Household Living Standards Survey } \\ \text { VND } & \text { Vietnam Living Standards Survey } \\ \text { WWF } & \text { Vietnamese dong } \\ & \text { World Wide Fund for Nature } \\ & \\ \text { FA } & \end{array}$




\section{Introduction}

This literature review concerns itself with the relationship in contemporary Vietnam between two sets of problems and ambitious national-level initiatives designed to address them. One issue is the persistence of extreme poverty and the program to eliminate it as a top government priority. The other is rapid deforestation and the determination of the government to slow it and restore large areas of forest cover that have been lost in the last half century.

At first glance, it would appear that these two themes have almost nothing to do with one another. Yet upon closer examination, we realize that not only are the problems intertwined, but appropriate resolution of both problems will require close scrutiny and understanding of their interlinkages. Therefore, a fitting point of departure for this literature review is to explain the basic elements of these two problems and the campaigns to address them, and explain why it is important to draw an analytical linkage between the two.

\section{Poverty and poverty alleviation in Vietnam}

Vietnam has long been, and continues to be, one of the poor countries in Asia. In 1975, after decades of war, the Vietnamese government sought to propel the country to a brighter future. Its initial efforts failed. By the mid-1980s, Vietnam was one of the world's most poverty-stricken countries, experiencing negative per capita economic growth and negative domestic savings, hyperinflation, widespread hunger, and hundreds of thousands of its citizens leaving the country in unsafe boats (Dollar and Litvack 1998:1 \& 5). What happened to cause such devastation? Agricultural production was exceedingly low in the early to mid-1980s, with only 300 kilograms of rice produced per capita per year. This is judged to be the level of subsistence in Vietnam, and a bad harvest reduced the average below 280 kilograms per person in 1987 (Dollar and Litvack 1998:3-4). Why was agricultural output so low? It was largely the result of forced collectivization after the end of the war, leading to a dramatic decline in agricultural output and hyperinflation (Irvin 1995:729). 
Yet from the mid-1980s through the mid-1990s, Vietnam set a new course and made an achievement that has been called "one of the most dramatic turnarounds in economic history" (Dollar and Litvack 1998:1) and "one of the greatest success stories in economic development" (ADB et al. 2003:11). Whereas in the mid-1970s, seven out of ten Vietnamese were living in poverty, ten years later the rate of poverty had been reduced by half (World Bank in Vietnam 2000:ii). In the period 1993-2002, poverty in Vietnam decreased from 58 to 29 percent according to a total poverty rate and from 25 to 11 percent according to a food poverty rate (ADB et al. 2003:9). ${ }^{1}$

In the early to mid-1990s, macroeconomic stability was restored; there was rapid export-led growth; rates of GDP growth reached 9-10 percent; and the rate of inflation had been reduced from 400 percent to single digits (Irvin 1995:726; Dollar and Litvack 1998:1 \& 11).

How was this economic miracle achieved? Essentially, it was through conversion of a centrally planned economy to a market economy. In late 1986 the government's Sixth Party Congress abandoned the socialist industrialization model and turned instead to agricultural-led growth. In 1988, through its Doi Moi (renovation) policies, the government abolished compulsory grain-purchase quotas and instituted free trade at market prices, ended collectivized agriculture, and distributed farmland to individual households (Irvin 1995:729-730; Dollar \& Litvack 1998:5). The reforms also legalized foreign direct investment and reduced or eliminated trade barriers (Glewwe et al. 2002:773). The reforms increased the relative prices of rice and other agricultural products, provided strong incentives for rural producers with land and agricultural knowledge, and by 1988 rice production per capita reached historical highs (almost 375 kilograms), 25 percent above the level of subsistence (Dollar and Litvack 1998:5-6, 11).

How was dramatic poverty alleviation achieved? The success in the early period can be explained by the distribution of land to agricultural households and the creation of economic incentives for increased farm production. ${ }^{2}$ The more recent achievements are explained by increased employment in the private sector and increased integration of agriculture into the market economy (ADB et al. 2003:i).

Although the poverty alleviation achievements of Vietnam are commendable, much remains to be done. No matter which poverty line is applied, the fact remains that there are many millions of poor people in the country-approximately 23 million according to the total poverty line, and nine million according to the food poverty line. And with a per capita Gross National Income of $\$ 410$ per capita in 2001, Vietnam is still classified as a low-income country (World Bank 2003:235). The government's target is to reduce poverty by 40 percent in the period 2000 to 2010 (Beard and Agrawal 2001:iv). Poverty is fundamentally a rural problem in Vietnam, with 90 percent of the poor living in rural areas and with incidence of poverty being much higher in rural areas (45 percent) than in urban ones (10-15 percent) (World Bank in Vietnam 2000:vi). Poverty in Vietnam will be mainly rural for the foreseeable future (ADB et al. 2003:1). For this reason, short- to medium-term poverty alleviation efforts will have to be heavily focused on agriculture and the rural sector and will have to focus on off-farm enterprises and services (World Bank in Vietnam 2000:viii; Glewwe et al. 2002:790). There is a basis for optimism for continued progress on poverty reduction with per capita GDP growth being 4.7 percent in the period 20002001 (World Bank 2003:235).

The future challenges in achieving poverty alleviation will be greater than in the past, however, because compared with the 1990s, fewer poor are clustered just below the poverty line, because rates of economic growth are lower than in 
the late 1990s, because of the need to target assistance to the poorest of the poor (Beard and Agrawal 2001:7), because much of the remaining poverty is located in inaccessible areas with unfavorable conditions for making a living (SRV 2002:18), and because poverty alleviation in these remote areas can be very expensive (ADB et al. 2003:iii). Inhabitants of these remote areas are disproportionately ethnic minorities whose rates of poverty are far above the national average (ADB et al. 2003:iii \& 9). The areas with the highest percentage of poverty are concentrated in the Northern Uplands, the Central Highlands, and the North Central Coast (World Bank in Vietnam 2000:vi; Minot and Baulch 2002:21-32; ADB et al. 2003:9).

\section{Deforestation and forest cover restoration}

Estimates of the change in forest cover in Vietnam in the last half century vary greatly. The forested area in Vietnam was estimated to be $181,500 \mathrm{~km}^{2}$ (55 percent of the total land area of $330,000 \mathrm{~km}^{2}$ ) in the late $1960 \mathrm{~s}$ and $56,680 \mathrm{~km}^{2}$ (17 percent of total) in the late 1980s (Collins et al. 1991:233; De Koninck 1999:3). According to De Koninck (1999:3), the loss of two-thirds of its forest cover in this period of time marks Vietnam as the most rapid case of deforestation among Southeast Asian countries. Vo Quy (1996 as seen in De Koninck 1999:9) says forest cover declined from 43 percent in 1943 to 20 percent in 1993. It is estimated that in the period 1976-1990, Vietnam's natural forest cover decreased on average 185,000 hectares per year (ADB 2000:i).

The area of present forest cover is a matter of controversy. A Vietnam government estimate claims the forest area in 2000 was $9,819,000$ hectares (30.2 percent of the total land area) (FAO 2003a:133), suggesting a substantial increase in forest cover since the late 1980s (see the figures above). Government sources claim there has been considerable restoration of forest cover in the 1990s through slowing of the rate of deforestation and through reforestation efforts, however some development observers dispute this claim (ADB 2000:i-ii). Lang (2001:113) says forest cover data in Vietnam vary greatly according to whether they are being used to draw attention to rapid deforestation, or conversely, whether they are being used to show that reforestation targets are being achieved.

According to the Asian Development Bank the main causes of deforestation in Vietnam have been population-driven demand for forest products and agricultural land and logging of large tracts of forest by State Forestry Enterprises (ADB 2000: i). De Koninck (1999:15) says the fundamental causes of rapid deforestation in Vietnam have been: "demographic growth; economic growth; an increasing demand for food and export crops; and an increasing demand for forest products-primarily wood for the pulp and paper industry, for construction, and for fuel." He identifies four "instrumental factors" in Vietnamese deforestation: (1) excessive reliance on swidden agriculture by some representative of ethnic minorities; (2) agricultural expansion; (3) logging, whether legal or illegal; and (4) collection of various forest products for subsistence needs (De Koninck 1999:15). Lang (2001:115-122) places emphasis on the role of governments and commercial enterprises in his explanation, and sees the following as key causal forces: (1) the second Indochina war and the use of bulldozers, bombs, herbicides and napalm by the U.S. military; ${ }^{3}(2)$ government resettlement programs, migration, and internal colonization in the post war period; and (3) logging by State Forest Enterprises (SFEs). De Koninck (1999:11) and Lang (2001:118-120) both remark that ethnic minorities have been wrongly accused of having a lead role in forest destruction in Vietnam. 
Among the alleged consequences of rapid deforestation have been soil loss in the uplands, siltation of downstream irrigation systems, increased severity of floods and droughts (ADB 2000:i) and severe biodiversity loss (Jamieson et al. 1998:3). Deforestation and forest degradation are assumed to have caused increased flooding and droughts, forcing the government to take drastic remedial measures.

Dating from 1992, the government of Vietnam has undertaken various efforts to stabilize and restore forest cover. In 1998, the Five Million Hectare Reforestation Program (5MHRP) was launched with the intent of increasing forest cover from approximately 9 million hectares (28 percent forest cover) to 14.3 million hectares (43 percent forest cover) in 2010 (MARD 2001:1 \& 5). Of the 5 million hectares of additional forest cover, 2 million hectares will be production forest, 2 million hectares will be protection and special use forests, and 1 million hectares will be perennial tree crops (ADB 2000:ii). The 5MHRP has three objectives. The environmental objective seeks to protect and rehabilitate watershed functions and to mitigate soil erosion and water discharge fluctuations. Through the economic objective the program strives to improve the role of the forest sector in overall economic growth. The social objective seeks to promote livelihood security among the most vulnerable groups in society (MARD 2001:vi).

\section{What is the relationship between poverty alleviation and the forest sector?}

What is the relationship between poverty alleviation and the forest sector in Vietnam? There are three key linkages, which can be described succinctly as follows:

1. There are important cause and effect relationships between the transformation of rural livelihoods and dramatic changes in forest cover because they occupy shared geographical space and have occurred in roughly the same time period.

2. Poor people in remote rural areas tend to have a relatively high level of dependence on goods and environmental services from natural forests for their sustenance. ${ }^{4}$

3. In spite of their dependence on forests, some rural people have derived great benefit from the elimination of forest cover through increased access to arable land and through conversion of timber and other forest products into income and capital.

Let us look at each of these three linkages in somewhat greater depth, beginning with the first and second. The areas of high incidence of poverty (ratio of poor to total population) in Vietnam (see Figure 1) tend to overlap with the location of remaining stands of natural forest (see Figure 2). Note that the areas of high incidence of poverty are concentrated in the northern and central highlands, away from Hanoi and other urban and coastal areas, and likewise the remnants of forest cover. (One important exception is the northwest corner of Vietnam, near the Chinese border, which is among the poorest in the country yet lacks forest cover. This is an area of relatively recent and rapid deforestation.) This convergence of the first and second linkages is not an accident. There are three main reasons for it. 


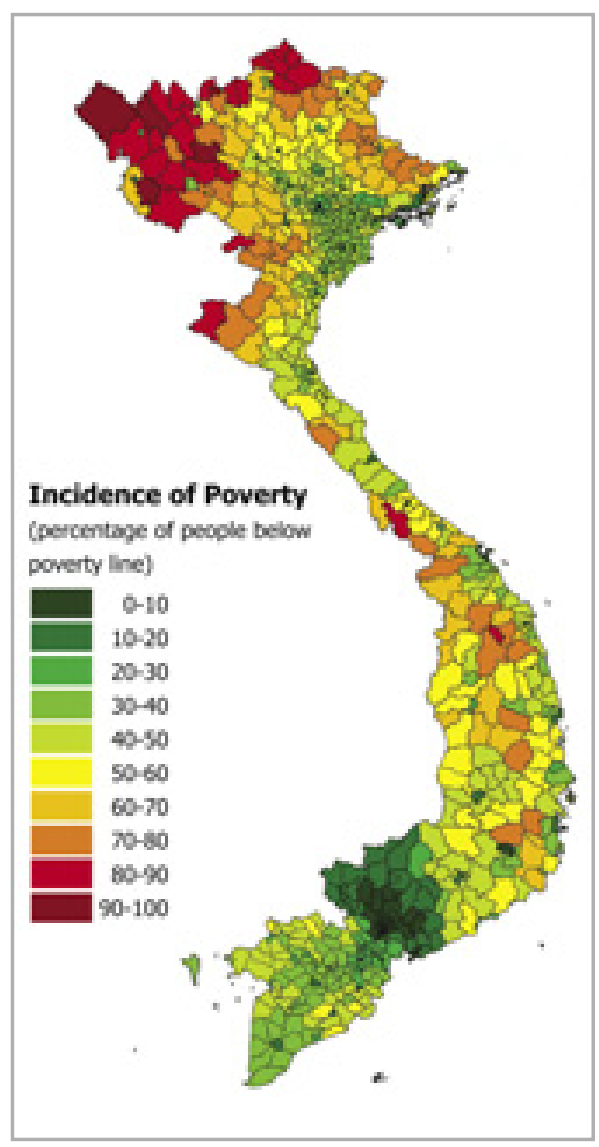

Figure 1. Incidence of poverty in Vietnam. Source: Minot et al. (2003).

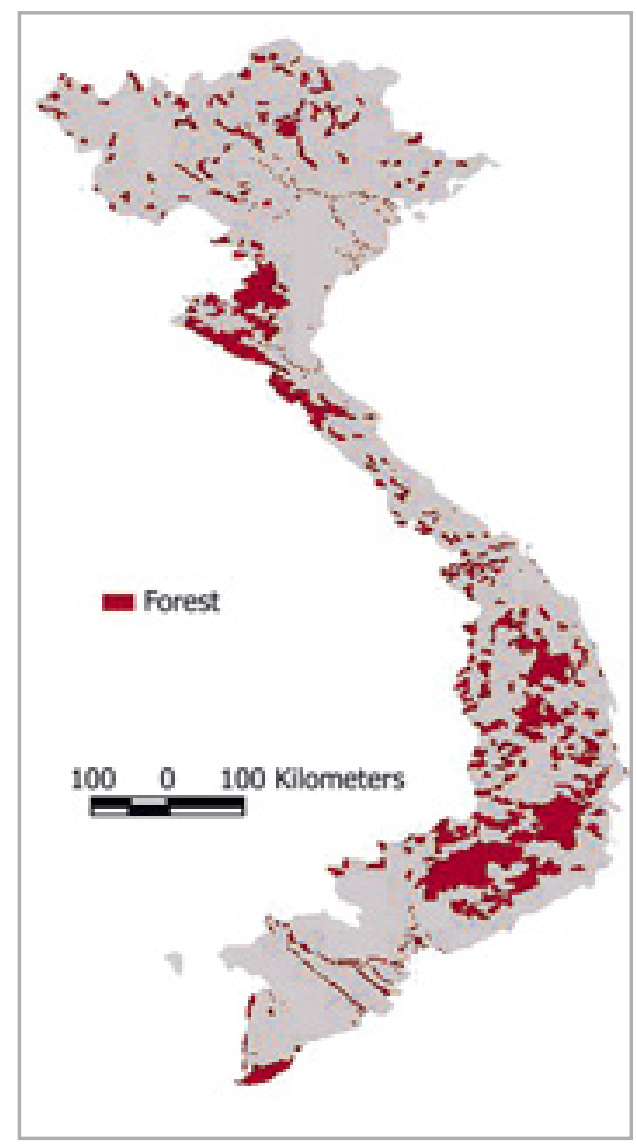

Figure 2. Remaining areas of natural forest cover in Vietnam, 1996. Source: Rhind \& Iremonger (1996).

First, many traditional ethnic peoples in the uplands of Vietnam have for centuries lived in the midst of forests. People in these areas are likely to be poor due to lack of access to markets, weak infrastructure, poor soils, and discrimination because of their ethnic origin. It makes sense that the rapid modernization of Vietnamese society and landscape are occurring last in the most remote areas of the country. Stated differently, the poorest of the poor are often located in areas that are remote from urban areas and from transportation thoroughfares, and this isolation and relative lack of contact with the wider economy is functionally related to their degree of poverty. ${ }^{5}$ And likewise, pockets of remaining natural forest tend to survive precisely because of their relative isolation from urban centers and from large roads-places where deforestation begins first and where rates of deforestation tend to be highest (until forests recede to a minimum). The patterns of socioeconomic development experienced in Vietnam have tended to concentrate poor people and remaining stands of natural forests in roughly the same geographical spaces, with some important exceptions. ${ }^{6}$ 
Second, in Vietnam, as in many other countries, remote forested areas have been destinations for colonization by poor people who have limited livelihood prospects in the crowded lowlands. It is not just ethnic minorities who live in the remote uplands, but also the Kinh majority.

Third, poor people in remote rural areas tend to have a relatively high dependence on access to forests for their livelihoods not just because of the geographical linkage (no. 1 above), but also because there are attributes of natural forest resources (especially of non-timber forest products or NTFPs) that lend themselves well to exploitation by the poor. (This will be explained in greater detail later on.)

With respect to the second and third key linkages of poverty alleviation and the forest sector, it is important to note that they appear to be in conflict with one another. The second linkage essentially says that forest protection and poverty avoidance are mutually reinforcing goals. The third linkage essentially says that forest protection and poverty avoidance are divergent goals. As shall be seen later, this ambivalence with respect to the role of forest resources is evident in Vietnam's literature on forest resources.

\section{The key questions posed in this literature review}

In view of the close linkage between the goal of continued poverty alleviation in Vietnam and concerns in the forestry sector, this literature review is focused on the following three questions:

1. Have forest resources in Vietnam served a useful role in poverty alleviation in the past?

2. Can forest resources in Vietnam serve a useful role in poverty alleviation in the future?

3. To what extent are forest-based poverty alleviation and massive reforestation through the 5MHRP ultimately compatible?

Clear answers to these questions are important because they have a bearing on the potential for success of both poverty alleviation and improved forest management. Based on what little we know, it is impossible to imagine a poverty alleviation strategy that does not give serious attention to forest resources. Many of the poorest of the poor in Vietnam live in or nearby forests and they make use of those forests in their livelihoods, so adequate attention to forest resources must be given in such strategies. Conversely, it is impossible to imagine a coherent national forest policy that does not focus on the implications of Vietnam's poverty eradication mandate. One way or another, massive rural poverty alleviation will affect plans for massive reforestation, and it is vitally important to anticipate how.

This review is comprised of six subsequent sections giving attention to: (1) theoretical background on the linkage between poverty alleviation and forests; (2) the methods used in conducting this review; (3) an examination of the literature in terms of six key themes; (4) discussion of two important policy developments regarding community forestry and benefit sharing; (5) a discussion of the research questions and synthesis; (6) ideas on future research directions; and (7) a summary and conclusions. 


\section{Forests and poverty: An emerging field of global inquiry}

In the 1960s, optimistic pronouncements were made by development organizations about the strong potential of using forest resources to assist the process of poverty alleviation in developing countries. It turned out that these predictions and promises went largely unfulfilled and a long period of disillusionment set in.

At the turn of the millennium, attention to this topic has been renewed. A literature has grown rapidly in recent years focused on examining the potential for forest-based poverty alleviation. Among the key titles are those by: Byron and Arnold (1999); Schmidt et al. (1999); Arnold (2001); FAO and DFID (2001); Gutman (2001); Wunder (2001); Scherr et al. (2002); and Smith and Scherr (2002); Oksanen and Mersmann (2002); Angelsen and Wunder (2003); FAO (2003b); and Oksanen et al. (2003).

A recurrent theme in this new literature is the need for additional research as there are many questions that remain to be answered (e.g., Angelsen and Wunder 2003:41). Views diverge on whether there should be grounds for optimism or pessimism for forest-based poverty alleviation. Scherr et al. (2002) can be viewed as leaning in the optimistic direction, whereas Wunder (2001) clearly favors a pessimistic view.

This section summarizes some of the key theoretical points set out in FAO (2003b). These theoretical points will serve as a conceptual framework to guide this literature review.

\section{Definitions of poverty, poverty alleviation, and forest- based poverty alleviation}

Poverty can be defined as a pronounced deprivation of well-being related to lack of material income or consumption, low levels of education and health, vulnerability and exposure to risk, no opportunity to be heard and powerlessness (World Bank 2001:15). Poverty alleviation can therefore be defined as a lessening of the deprivation of well-being. Following FAO (2003b:61), this book specifies two types of forest-based poverty alleviation applied at the household level. These are: 
- poverty avoidance or mitigation, that is, a situation where forest resources serve to prevent people from slipping into poverty, or from becoming more poor if they are already poor, and in this sense, they serve as a safety net or as a gap filler, including as a source of petty cash; and

- poverty elimination, that is, a situation where forest resources help lift the household out of poverty by functioning as a source of savings, investment, accumulation, asset building, livelihood diversification, and permanent increases in income and welfare.

It is important to emphasize the qualitative difference between these two types of forest-based poverty alleviation (hereafter "FBPA"). Under conditions of poverty avoidance or mitigation, the people in question remain below or close to the poverty line, but are less poor than they otherwise might have been. By contrast, those experiencing poverty elimination achieve a considerable and long-lasting improvement in their socioeconomic status. FBPA should therefore be understood as a broad term, encompassing very different meanings that include both of the subforms defined above. In addition, it must be understood that FBPA is almost never a stand-alone process. The role forests and trees play in alleviating poverty is usually linked to other kinds of livelihoods, including agriculture, rearing of livestock, and others (FAO 2003b:61).

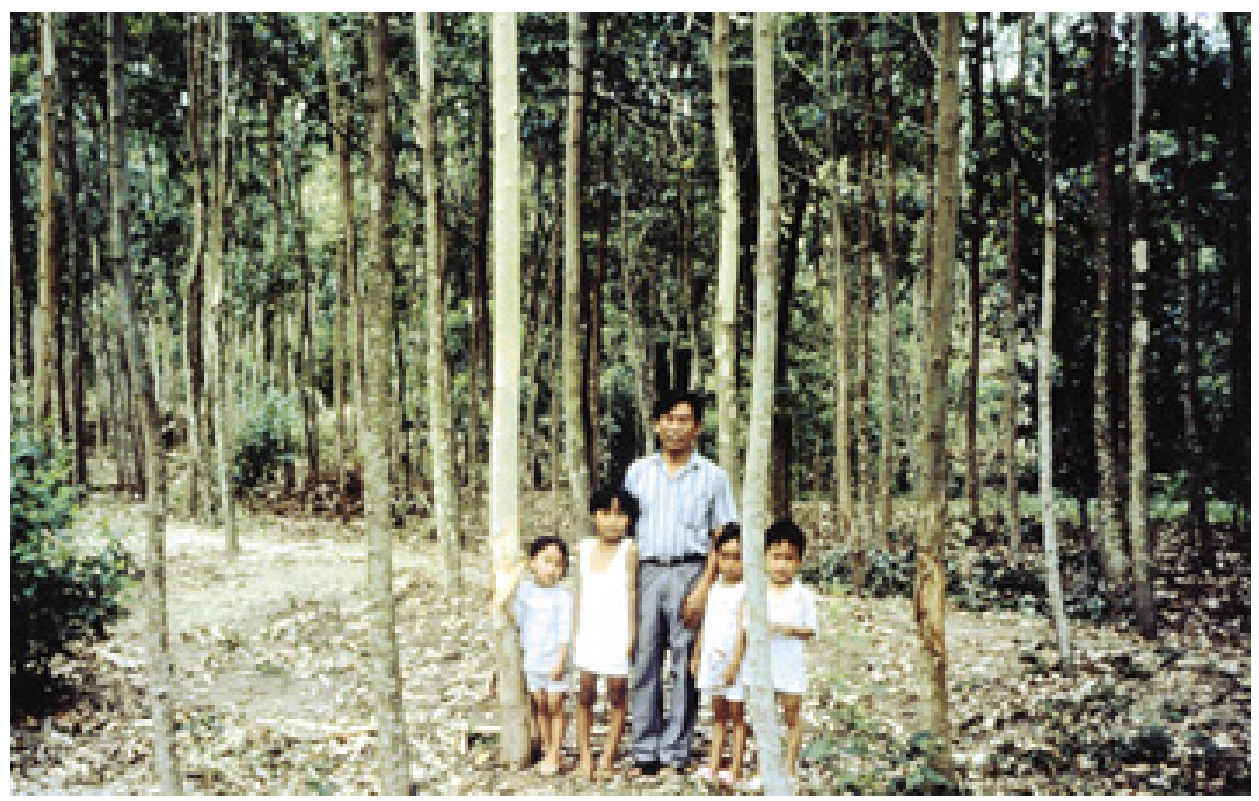

Eucalyptus cash crop (Photo by Neil Byron)

It is also useful to distinguish between the "forest" poor (i.e., those whose wellbeing is influenced by their proximity to forests and their use of forest resources) and the "downstream" poor (those whose wellbeing is affected by forests though they may live far from forests). This distinction is important in Vietnam because one of the major justifications of the 5MHRP is the assumed negative effect of forest cover loss on lowland agriculture and people. And although the proportion of 
people in poverty tends to be higher in the remote uplands than in the lowlands, the absolute numbers of poor tend to be concentrated in lowland and urban areas. In spite of the importance of this distinction, we will be focusing largely on the forest poor in our discussion. The reason is that the downstream effects of forest sector change have barely been documented.

\section{Modes of FBPA}

FAO (2003b:62-67) identifies six modes of forest resource use that can potentially assist the process of poverty alleviation. These are:

1. Conversion of forests to agriculture. It is seldom understood that conversion of forests to agriculture is one of the major ways that forests can alleviate poverty. The reduction or removal of forest cover-either on a permanent or temporary basis-frees up land for the establishment and expansion of agriculture and pastoral activities. Moreover, in the same step, it can facilitate access to wood products.

2. Timber. ${ }^{7}$ On an annual basis the value of commercial timber in forested developing countries is billions of dollars. ${ }^{8}$ On the basis of this information alone, one has to wonder why more of this extraordinary wealth cannot be used to assist poverty alleviation. The reasons for lack of success include the lack of power of the poor to confront elites who lay claim to forest resources (and linked to that, anti-poor tenure and regulatory policies) and the antipoor characteristics of timber (i.e., tending to require economies of scale, access to specialized markets, secure land tenure, a long time horizon, and capacity to engage in risk). While there are some promising models of smallscale, locally managed timber production, these tend to be hampered by weak institutional support among other obstacles.

3. Non-timber forest products (NTFPs). Among these products are: charcoal, fuelwood, game, fruit, nuts, medicinal herbs, forage, and thatch for roofs. The poorest of the poor tend to be those who depend on NTFPs and this raises the question of whether dependence on NTFPs is good or bad. A positive outlook on this issue views NTFPs as a "safety net," which is to say, they provide a source of emergency sustenance in times of hardship. In some cases, NTFPs can be a source of prosperity if they are intensively managed and produced under conditions of secure tenure and good market access. A negative outlook contends that NTFPs are a "poverty trap" in the sense that dependence on them undermines possibilities for savings and investment in various ways and therefore limit potential for generating increased income.

4. Environmental services. Forests provide direct environmental services of various kinds to people living in the vicinity of forests-among them: restoration of soil fertility in rotational agricultural systems; protection of water quantity and quality; and forage for cattle, pollination, weed control, and maintenance of biodiversity including germplasm for agriculture. These direct environmental services tend to be associated with the poverty avoidance/mitigation definition of FBPA. Forests also provide indirect environmental services to people living at a distance from forests, and the poor can benefit from efforts to maintain these services through transfer payments by off-site users to forest dwellers. Examples of such payments are: carbon storage and sequestration schemes; integrated conservation and 
development projects (ICDPs); schemes to protect hydrological services; and forest-based tourism.

5. Employment. In the late 1990s, there were 17.4 million employees worldwide in the formal forestry sector and about 47 million altogether including formal and informal employment (ILO 2001:39).

6. Indirect benefits. There are two forms of indirect forest benefits through which poverty alleviation can be attained: local multiplier effects; and trickle-down effects. Local multiplier effects are those in which forest-based economic activities can lead to livelihood improvements for forest dwellers that would not have otherwise occurred. Examples are: (1) the opening of a logging concession can create income opportunities in the provision of food, shelter, and services for the logging crew; (2) the creation of logging roads can open up marketing channels and therefore increase incomes; and (3) concessionaires sometimes compensate the disruption of local economies through the construction of schools or other facilities. Trickle-down effects are those where timber sector development produces revenue for the national treasury and foreign exchange for the country's balance of payments, which in turn might be used for poverty-reducing investments in forest communities. Although one can surmise the indirect effects could be very strong in timber-rich countries, there are few empirical studies documenting this phenomenon.

\section{Convergence or divergence of poverty alleviation and forest condition}

Does the process of socioeconomic development and poverty alleviation favor the maintenance of forest cover and forest quality, or does it undermine it? And conversely, is the maintenance of forest cover and forest quality consistent with national poverty alleviation programs, or does it run counter to it?

There is a strongly held belief in much of the literature on environment and development saying that socioeconomic development and environmental conservation, generally speaking, are compatible goals. This assumed lockstep relationship between poverty alleviation and environmental betterment is epitomized by the following quotation from Our Common Future, one of the key documents in the literature on sustainable development:

“...poverty is a major cause and effect of environmental problems. It is therefore futile to attempt to deal with environmental problems without a broader perspective that encompasses the factors underlying world poverty and international inequality" (WCED 1987:3)

Yet there is every reason to believe-even without the benefit of empirical data in hand-that some forms of economic development and poverty alleviation are achieved not in conjunction with environment betterment, but rather through environmental deterioration. For example, permanent conversion of forest lands to agriculture (FBPA mode 1 above) has undoubtedly been associated, on average, with increased resource use and increased per capita income where it has happened.

Ambivalence about the convergence or divergence of socioeconomic development and environmental betterment are increasingly evident, including in Vietnamese 
reports. For example, there are observers who believe forest cover loss underlies deepening poverty in Vietnam (e.g., Jamieson et al. 1998:4; MARD 2001:6), whereas at the other extreme there are observers who believe forest depletion is part and parcel of the process of poverty alleviation (e.g., ADB 2000:i). In reality both processes coexist, and both must be recognized and understood. In light of the indeterminacy of social and environmental consequences in the development process, it is best to avoid rigid theoretical preconceptions and instead assume the widest possible array of outcomes, as shown in Figure 3.

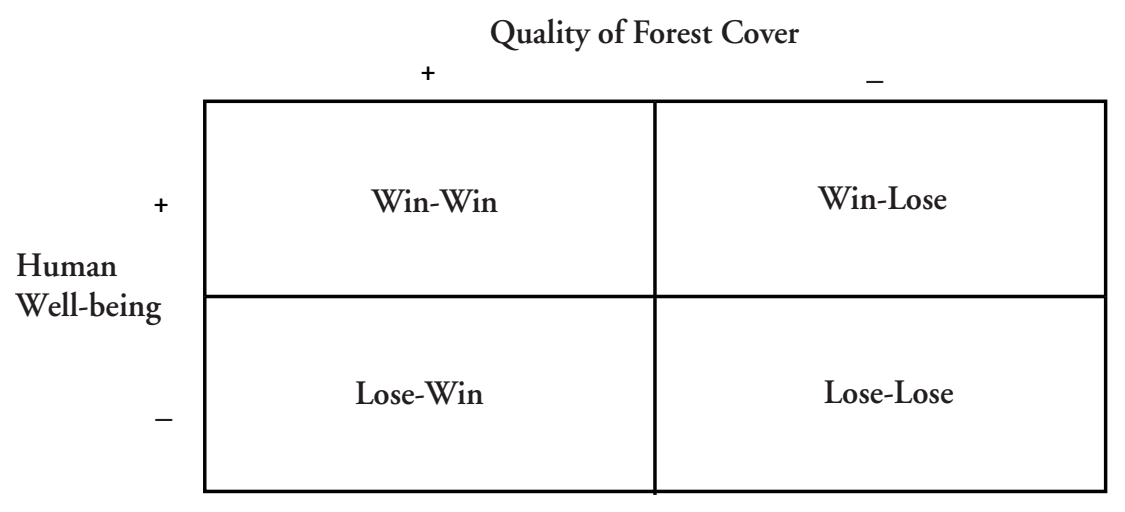

Figure 3. Four-fold classification model of human well-being and forest cover. Source: Sunderlin (2003).

This model, applied to the case of forest dwellers and forests, assumes the following definitions:

- "Win-win" means poverty alleviation and environmental protection are assumed to go hand-in-hand.

- "Win-lose" means poverty alleviation happen at the expense of forests and biodiversity.

- "Lose-win" outcomes occur when livelihood security is undermined by excluding local people from forests.

- "Lose-lose" outcomes mean that both local people and the environment lose out.

This model is, arguably, a gross over-simplification of what happens in the real world. In reality, there can be a great multiplicity of outcomes in one location. For example, there are often "winners" and "losers" in the same community, and sometimes within the same household. Nonetheless, we believe this is a key theoretical point of departure for making sense of broad tendencies taking place in the Vietnamese landscape. 


\section{The approach of this review}

This review was undertaken recognizing that the topic of poverty alleviation and forests is growing in importance in Vietnam. Policy decisions at the juncture of poverty alleviation and forests in Vietnam, at all levels of government, will depend critically on good information, and this information, in turn, will depend on research, given that almost no research has been done specifically on this subject. At the time of this writing, CIFOR is in the preparatory stages of implementing field research on this topic in Vietnam, Cambodia, and Laos.

We see three specific factors justifying this review:

1. There has been much written about poverty alleviation in Vietnam, and much has been written about the forestry sector, yet these are almost wholly separate literatures with separate readerships even though, as we have seen above, there are strong reasons for understanding the relationships between these bodies of knowledge.

2. A literature review is customarily a good starting point before undertaking primary field research, not just for the purpose of synthesizing published information, and for giving attention to important new knowledge, but also for the purpose of defining relevant and useful research questions and hypotheses in preparation for primary field research.

3. Ideally, given the size of the information gap at the interface of poverty alleviation and forests in Vietnam, primary field research is necessary that is squarely focused on this issue. However such research will take years to achieve, and in the meantime, it is important to glean whatever knowledge can be obtained through the existing literature.

Understanding that it would be impossible to analyze all the literature on poverty in Vietnam, as well as all forestry literature, we decided to read and analyze that subsection of both bodies of knowledge that had the highest possibility of meeting 
minimum criteria of relevance. Specifically, we focused our attention on that portion of the literature on poverty alleviation that gave some attention to forests and natural resources, and conversely, we read documents in the forestry literature that gave attention to poverty and livelihoods improvement. We accumulated documents in both Vietnamese and English knowing that both would be relevant and that not all key documents are both in Vietnamese and English. We make no claim that we have found all the relevant documents and suspect that some have escaped our attention given the time constraints under which we were operating.

We began by identifying documents in the formal literature that could be identified by key word searches in bibliographic databases. But it became clear that there are many relevant "grey literature" documents that could only be found by tracking them down. One of us (Thu $\mathrm{Ba}$ ) made visits to donor organizations, research institutes, government offices, NGOs, and university libraries to peruse their documents and make photocopies. Such visits were made in Hanoi, as well as in Daklak province and Ho Chi Minh City.

It is important to flag two problems that surfaced in the course of our literature review. First, in some cases we relied on information dating back to the early or mid-1990s because we lacked more recent information on a given issue. Some of the issues raised in that literature may have been resolved without us knowing it. Second, in analyzing and synthesizing the material we gathered, we have often taken the literature at face value, making little allowance for the fact that some of it may not be well grounded empirically. We did this because we did not have the time or the means to independently verify claims made by others. Some of our analysis therefore involves a leap of faith, and this may be a weakness. Nevertheless, we have made an effort to be clear where our opinions differ from those of others. 


\section{The literature review}

In this section, we have clustered the literature according to the six FBPA modes described above, believing this is the best way to address the three research questions systematically and clearly.

\section{Conversion of forests to agriculture}

Conversion of forests to agriculture-either temporarily as in swidden cultivation, or permanently through sedentary agriculture-has for centuries been one of the main foundations of rural livelihoods in Vietnam. In this section we focus our attention on the slow decay of swidden cultivation in the remote uplands and the gradual turn to other livelihoods, including sedentary agriculture and increased farmer production of cash crops. This transition has been propelled in part by Doi Moi policies and the allocation of forest lands to individual households.

\section{Problems of swidden cultivation}

In the year 2000, Vietnam's rural population was 58 million people out of a total population of 77 million (EIU 2001:48). Nine million rural people from 50 different ethnic minorities in Vietnam practice swidden cultivation, and of these, three million earn their living mainly from this source of income (Do Dinh Sam 1994:5). Rice and corn are the staple swidden crops, and cassava is considered an emergency food, though it is sometimes marketed in places where road access is good (Le Trong Cuc 1997:56).

Although it has long been a relatively reliable source of sustenance, some swidden systems have entered into a period of decline in recent decades. In some cases, the outcome can be considered "lose-lose" in the sense that incomes are declining at the same time that available resources are being degraded. Jamieson et al. (1998:10) in the "The Development Crisis in Vietnam's Mountains" state that it 


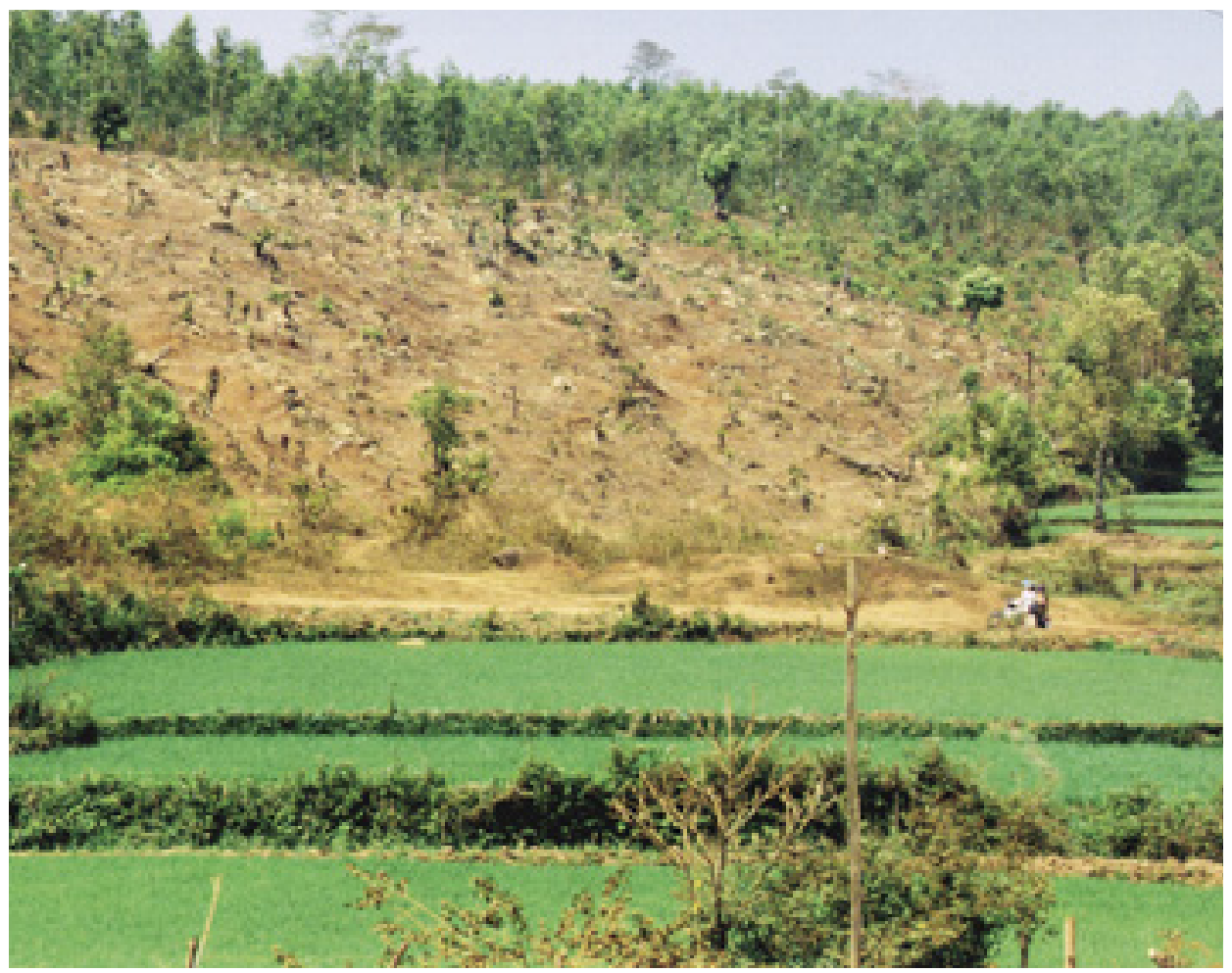

Forest cleared on a hillside (Photo by Philippe Guizol)

is increasingly difficult for millions of households in the uplands to meet their basic subsistence needs because yields in swidden fields have declined to as low as 400 to 600 kilograms of rice per hectare, as compared to six or seven tons per hectare in the Red River Delta. In the period 1994 through 1999, the annual average food yield (including just rice, cassava and maize) in the Ka Tu community decreased from 200 kilograms to 170 kilograms per capita (Nguyen Thi Cach 1999:34). A combination of factors has caused this decline. Growing population pressure has led to a shortening of the fallow period and associated overuse of soils without sufficient regeneration in fallow, leading to decreasing average yields over time. Some of the population pressure results from the growth of ethnic minority groups themselves, and some results from the colonization of upland areas by outsiders who are not ethnic minorities. In the northern uplands, the population tripled between 1960 and 1984 because of these two sources of population growth (Jamieson et al. 1998:10).

Theoretically, some of this population and resource pressure could be alleviated through the development of alternative livelihoods. Though some progress has been made in this direction, it has been very restricted. One reason for limited progress has been cultural resistance on the part of ethnic minorities. According to a government report on the current poverty situation in Vietnam, a majority of the poor choose the strategy of self-sufficiency and stick to their traditional mode of production (swidden cultivation), even though it generates low value (NIAPP 1999:4). Another reason for limited progress in creating alternatives to swidden cultivation has been the inadequacy of the measures themselves. 
For decades, the Government of Vietnam has been implementing a policy of sedentarization and New Economic Zones (NEZ) aimed at stopping the practice of swidden cultivation and introducing fixed agriculture. It has been assumed that through this program poverty alleviation and cessation of forest destruction could be achieved. In recent years, some observers have questioned the assumption that swidden cultivation is a leading cause of deforestation in Vietnam, pointing out that the agricultural practices of the dominant Kinh ethnic group can be far more destructive (e.g., De Koninck 1999:88). One recent Ministry of Agriculture and Rural Development (MARD) document agrees with this view, pointing out that “... the assumption that ethnic minorities are principally responsible for forest clearance would be a misleading one within the framework of the 5MHRP initiatives" (MARD/ ICD 2001:52).

The aim of the sedentarization program was to generate 80 percent of total income from fixed agriculture by increasing the area of wet rice in the uplands and by encouraging the production of forest and cash crops (ADB 2001:14). Yet after decades, the sedentarization and NEZ programs have not reduced poverty and the number of swidden cultivators has not been reduced significantly (ADB 2001:14). Other studies report that although swidden cultivation has almost stopped in many villages in the uplands, families continue to seek land for swidden agriculture, especially in emergency cases (e.g., a family member has fallen sick, a food shortage has occurred, etc.) (Tran Ngoc Thanh 2000b:18).

\section{Increased production of agricultural commodities}

In recent years, the dynamic growth of the agricultural sector through the development of forest lands for perennial crops (e.g., coffee, tea, rubber, and cashew nut) has substantially improved the incomes and welfare of the rural population (ADB 2001:2). In the period 1993 to 1998, agricultural incomes grew by 61 percent and are the main factor explaining dramatic increases in household income (World Bank in Vietnam 2000:51). Agricultural exports grew spectacularly, almost doubling in the period 1988 to 1991 and accounting for more than half of the value of all Vietnamese exports (Fforde and Sénèque 1995:104). In the period 1990 to 1999, the area of land sown to crops in Vietnam grew 3.4 percent per year and reached a total of 12.3 million hectares (EIU 2001:30). It is not clear how much of this agricultural expansion took place at the expense of forest cover.

In this section we give attention to two commodities that have particular importance at the nexus of changing rural livelihoods and forests in Vietnam: coffee and livestock. Our treatment of this subject is necessarily brief because of insufficient documentation on key points of information.

In the course of last two decades Vietnam has witnessed explosive expansion in the production of coffee, particularly in Gia Lai and Daklak provinces in the Central Highlands. The area planted to coffee expanded nine-fold from 44,700 to 397,400 hectares, and the output increased 40 -fold from 12,300 to 486,800 tonnes. In 2000 Vietnam became the second leading coffee exporter in the world (by volume) after Brazil (EIU 2001:30). The role of the coffee boom in forest cover removal in the Central Highlands is said to be large, but the data on this are scarce and anecdotal. ${ }^{9}$ Although the coffee boom contributed to livelihood improvements for growers, it has also had an unexpected downside. Worldwide overproduction of coffee-induced in part by Vietnam's volume increase-has depressed prices and has dramatically lowered income for coffee producers (Johnston 2001). We found no information 
on the commodity-specific role of the coffee boom in rural poverty alleviation, nor on the degree to which overproduction has affected the wellbeing of producers in Vietnam.

Livestock husbandry has been increasing in Vietnam in recent years. In the period 1995-1999 the number of cattle has increased from 3.6 to 4.0 million while the buffalo population was steady at 2.9 million (EIU 2001:54). Among the factors propelling expansion in Cho Don district, Bac Kan province are a growing population and growing demand for beef in urban areas, and increased use of cattle as a form of capital because of increasing land scarcity (SAM Program 2003:2-3).

The northern mountains offer good conditions for livestock production and this is why in 1994 more than half the buffalo population was located there (Rambo 1997:36). Livestock are almost an ideal cash crop for the uplands because they fill an otherwise empty niche in swidden systems; livestock fodder is available in fallow plots and secondary forests (Rambo 1997:36). Some upland regions have a reputation for high value cattle products. For instance, the limestone mountain area of MeoVac (Ha Giang Province) is well known for its beef cattle production. The sale of cattle provides a large source of income for Hmong farmers (Shanks 2002:4). The forest areas of Tuyen Quang and Bac Kan provinces offer a good source of fodder and space for raising buffalo, which are traded not only throughout the delta regions but also to Laos and Thailand (Shanks 2002: 4). The Mountain Rural Development Programme suggested there is a need to reserve some open areas for production of fodder for cattle production, especially in more remote areas where animal production is a major income generating activity (MRDP 2001:5-7).

There is some evidence linking the growth of the livestock sector to the elimination of forest cover in the northern uplands. For example, Rambo (1997:37) explains that in Lang Son province "barren hills" were created long ago for the purpose of livestock pasture; efforts to reforest in these areas contradict farmers' needs to maintain their areas of pasture. Researchers in the SAM Program (2003), on the basis of a case study in Cho Don district, Bac Kan province in northern Vietnam, explain that rapid growth in the herd of large ruminants (cattle and buffalo) has put unsustainable pressure on forest cover. Nevertheless, there is a large information gap. It is not known to what extent expansion of the area of pasture is happening at the expense of natural forest cover at the national level.

\section{The turn to forest land allocation}

As mentioned earlier, decollectivization of agriculture and allocation of land to individual households were critical to success of Doi Moi policies and to dramatic economic growth and poverty alleviation since the late 1980s. The Land Law of 1993 gave farmers the right to inherit, mortgage, transfer, exchange, and lease land. As of 1999, about 10 million households had received Land Use Certificates, mostly in lowland areas (Huynh Thu Ba et al. 2002:23).

Forest land allocation (FLA) is an important sub-component of this program. It is a radical policy shift involving devolution of forest management authority from the state to the local level. The goal of the FLA has been to encourage the protection and restoration of forest cover in the uplands, and the rationale of devolution was that villagers would be more interested in forest protection and management if they had formal rights to forest land (Sikor 2001:4-5). The Land Law required that land classified as forests must be restricted to that use, and subsequent decrees said natural forests and forests in sensitive watersheds could be allocated to communes, 
districts, and State Forest Enterprises (SFEs), but not to households (Sikor 2001:5). Villagers to whom forest lands were allocated were awarded small cash payments for protecting the forests on their land and were given subsidies for tree planting (Sikor 2001:5). These subsidies are provided only on protected and special use forests, not production forests. ${ }^{10}$ Protection forests cover a large share of all upland forests, more so in the northern uplands than in the center and Central Highlands. In almost all provinces, households are allocated mostly barren lands and planted forests. In those provinces, natural forests are allocated to local government units, which may then contract local households to protect the forest. The province of Daklak stands out for allocating natural forest land to households and communities. ${ }^{11}$

Despite the significant progress made in the allocation of farmland since the Land Law of 1993, the allocation of forest land has lagged behind considerably (Sikor 1998:30; Huynh Thu Ba et al. 2002:35). Although 61 percent of the 10.8 million hectares of forest land has been allocated, two-thirds of the total has been allocated to SFEs, which in turn are supposed to reallocate the land to households. Only 10 percent of the total area of forest land has been allocated directly to households. This allocation, to 334,446 households, results in an average holding of 3.2 hectares per household. A further 500,000 hectares have been allocated to 1,677 collectives (Huynh Thu Ba et al. 2002:11).

It is important to point out why we classify the FLA program under the heading of poverty alleviation through "conversion of forests to agriculture." Some readers will rightly ask why we do this, given that the FLA is formally intended to maintain natural cover and to provide income through forestry activities. The reason is that, in spite of this formal intent, a portion of allocated forest land is often converted to

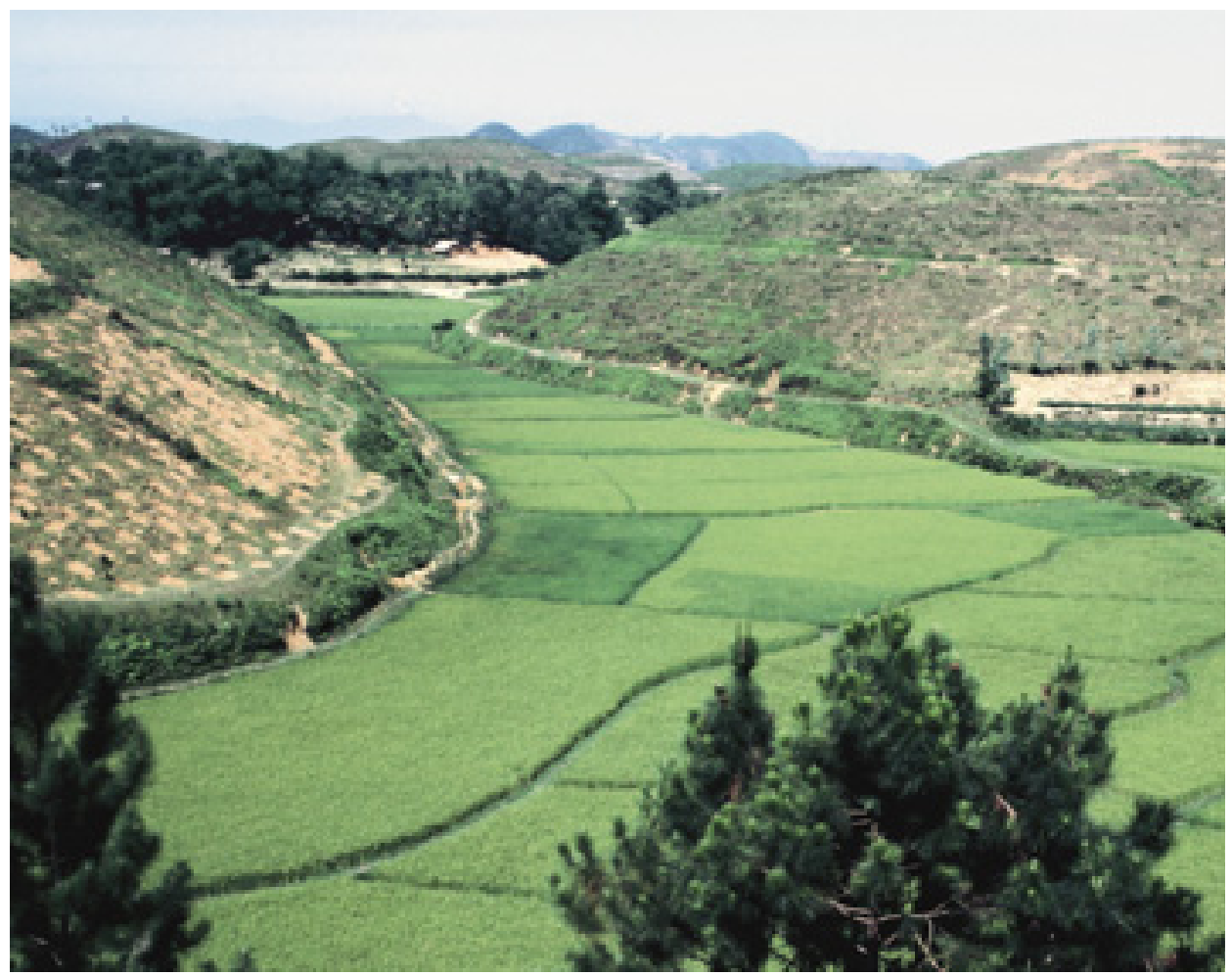

Wet rice agriculture and hillside agriculture (Photo by Christian Cossalter) 
agriculture or other non-forest land uses either illicitly or through relatively recent adaptations of FLA regulations that allow conversion. ${ }^{12}$ Although it is not clear that agricultural activities have been the main source of income to FLA participants, they apparently are sufficiently large to justify inclusion under this heading. This does not alter the fact that some FLA beneficiaries do in fact maintain and in some cases improve forest cover on allocated land, and some of the benefits to recipients are non-agricultural. We classify the FLA program in this section as a matter of convenience, recognizing it can be classified under other headings as well.

What has been the success of FLA to date in improving the livelihoods of the poor and in maintaining forest cover in the highlands of Vietnam? The available literature presents a very ambiguous picture.

\section{Positive assessment of FLA and the reasons for success}

In some areas, it was reported that after forest land allocation, local peoples' control over land and land use increased, resulting in reforestation and greater benefits for forest planters (Thanh Nhan 1998:12). In the lowlands and parts of the midlands, forest land allocation increased forest use rights for local people (Thanh Nhan 1998:8). Research by the International Development Research Centre indicates that forest cover and quality improved dramatically after a few years of implementing land allocation to farmers for long-term management. Benefits from managing forests included secured irrigation water, intercropping products, thinning cuttings, fuelwood and other NTFPs (Bellamy 2000:2). Howard (1998:249) contends that the allocation of forest and agricultural land has led since 1995 to "an annual net gain in forest cover with plantation area exceeding forest loss to fire or conversion."

Sikor (2001:8) says there has been an expansion of forest cover over the period that forest land has been allocated, but claims it results mainly from the liberalization of agricultural output markets and the availability of new technology, and not from the FLA. As fallow cycles in swidden areas shortened, returns to labor in wet-rice cultivation began to exceed those in rice swidden cultivation, wet rice production increased dramatically, and forest-consuming rice swiddening declined. ${ }^{13}$ Moreover, at the same time, because of increased demand for animal feed in the lowlands, demand for corn increased in comparison to cassava. Corn yields tripled without the use of fertilizers or pesticides, enabling forest regeneration (Sikor 2001:8-10).

Various success stories reported are specific to particular locations:

- In Bac Giang province, after receiving allocated land, local people became enthusiastic about re-zoning the land in order to better exploit barren hill lands and establish forest tree plantations. In this case, forest land allocation not only helped to inspire people to improve their household income, but also to overcome landlessness and poverty. After receiving land, area residents had a greater sense of ownership and channeled their resources into renovating production methods, seeking and investing in new technology and more appropriate forest tree species, and enhancing productivity and quality of agroforestry products (Nguyen Xuan Thanh et al. 2000:43-46).

- Experiences from the Social Forestry Development Program (SFDP) show that forest land allocation and the issuing of Forest Protection Contracts (FPCs), in combination with the subsidies from Program 327, have had a positive impact on forest protection (Apel and Pham Van Viet 1997:14). (FPCs and Program 327 are explained in detail later in this report.) 
- Researchers in Vinh Phuc province observed an impressive increase in crop yields and reforestation of formerly barren hills after forest land allocation (Le Trong Cuc et al.1996:67).

- It was reported by the Department of Agriculture and Rural Development in Thanh Hoa province that in almost every district of the province there are households improving their incomes through forestry, thus lessening the rate of unemployment in the province. It is necessary to note that those who were successful in developing forest farms were those with management skills, a clear development plan, and sufficient capital (Khuong Ba Tuan 1998:39).

- In some northern provinces, fruit trees have replaced cassava on forest land allocated to farmers. In Dong Sung village, the entire Tay population now grows litchi. This has helped to lift some families out of poverty, and some better off families have managed to accumulate a considerable amount of capital (10 million Vietnamese dong (VND) annually) ${ }^{14}$ as a basis for economic development (Nguyen Thi Thu 1999:43; Le Thi Ngan and Nguyen Thi Tho 2000:32).

- The forest land allocation policies in Daklak province demonstrate one of the most progressive efforts in Vietnam in moving toward community forestry. Local farmers are allowed to harvest NTFPs and are entitled to 6 percent of the total value of cut timber for every year they manage the forest (Tran Ngoc Thanh 2001:23).

- In village of Bu Nor, Dak R' Lap district, Dak Nong province, household groups enriched forests on allocated forest lands with indigenous trees species (Dipterocarpus alatus, Hopea odorata, Cinnamomum cassia, and bamboo for shoot) and set up tree nurseries to restore their fallow lands. Villagers were allowed access to timber through thinning, and some households were able to get 3.5-4 million VND from this activity (Bao Huy 2003).

\section{Negative assessments of FLA and the reasons for failure}

A negative view of the FLA program emerges from other sources. The experience of the Social Forestry Development Program (SFDP) shows that forest land allocation, together with incentives for planting trees, failed to achieve success in upland areas in Vietnam (Pham Ngoc Due 1999:5). Forest land allocation and tree planting do not appear to be central for agricultural production and household subsistence. This observation is backed up by statistics and evidence of the VLSS and SFDP surveys, which show that production forestry (with the exception of households specializing in tree crops supplying pulp and woodchip mills or growing coffee, tea or rubber) is a minor part of farming systems and provides a small proportion of family income (ADB 2000:53). This portrayal implies that policy makers need to think beyond FLA towards systems of incentives that would enable forest management to deliver greater livelihood improvements. ${ }^{15}$

Various authors point out weaknesses of the program that can be clustered in five categories: (1) incompatibility with local livelihood practices; (2) relationship of the program to State Forest Enterprises (SFEs); (3) equity; (4) geographic and logistical issues; and (5) policy errors.

\section{(1) Incompatibility with local livelihood practices}

For practitioners of swidden cultivation, forest land allocation has little value because in receiving a relatively small parcel of land they lose their traditional freedom and 
run the risk of degrading rather than maintaining soil fertility by using the same parcel over and over again (Nguyen Van San and Gilmour 1999:28). A case study in Bac Can province shows that allocation of forest land to individual households reduced free access to land and created difficulties for groups that traditionally migrated and depended on swidden cultivation (Castella et al. 2002:197). A survey concluded that poorer ethnic minorities preferred community forest management due to their primary concern of ensuring food security, while the Kinh and Thai people value forest land allocation to individuals (Tran Duc Vien 1999:45). A similar observation is made by Tessier (2002:18). Ethnic minorities tend to gather a large variety of forest products over a wide area, and this area exceeds the bounds of an individual plot of forest land. ${ }^{16}$ Some people are reluctant to receive allocated parcels of land and invest in forestry for fear this will require them to stop clearing other land for illegal cultivation outside their communes (Sikor 1998:26-29) and because allocation weakens rather than strengthens their control (Sikor 2001:7). Apel (2000:5) states that the FLA model has been detrimental to forest development in the uplands because it has eroded traditional resource management systems. Lands classified as "unused" by the government and subject to allocation often do in fact have a defined land user, but the government rarely acknowledges the existence of such institutions (Nguyen Van San and Gilmour 1999:28).

It is important to note that these deficiencies might be remedied in the future through recent changes in the Land Law, which will enable allocation of forest lands to communities. (See the section on community forestry and benefit sharing later in this document.)

\section{(2) Relationship of the program to SFEs}

A forestry development strategy document states that about three-quarters of all lands available for distribution through the FLA have been allocated, but no economic momentum has been created for forest owners to actively protect and develop forests (MARD 2002). In reality, most of forest land allocated went to SFEs, which subsequently reallocated some lands to their employees and local farmers with few rights or no use rights (ADB 2001:52). Sometimes households' residential and agricultural lands with land allocation certificates (commonly referred to as "Red Books") are mistakenly considered SFE land. A related and important source of confusion is that forest land is sometimes considered "allocated" if Forest Protection Contracts (sometimes referred to as "Green Books") have been issued rather than the more secure and long-term land allocation certificates (Red Books). ${ }^{17}$ It was found that forest land allocation in some cases contributed to resolve conflicts between local people and SFEs. However, in other areas, conflicts were intensified. Due to poor mapping, some previously allocated forest lands have been designated for other purposes (Huynh Thu Ba et al. 2002:65). SFEs continue to have a leading role in forest management, and this can be seen from the fact that forests can only be allocated to households if they are released by SFEs (Lang 2001:121). The process of forest land allocation in many locations is hampered by the SFEs' reluctance to give up its management power over forest areas to local households or organizations despite its incapability to properly carry out the job (Vu Huu Tuynh 2001:6). The process might also be hampered by local governments because of provincial forestry cash flows.

A policy decision made years ago, if implemented appropriately, may ease the problems described above. MARD's Decision 187, which calls for a drastic overhaul and restructuring of remaining SFEs, should have the effect of forcing SFEs to 
release forest lands to households and communities. Poor progress in implementing this decision (largely because the central government had previously decentralized control of SFEs to provincial governments) has led the Politburo to issue Resolution 28 , which calls for more rapid progress. ${ }^{18}$

\section{(3) Equity}

Allocation of land is often inequitable with over-allocation for mass organizations, employees of SFEs, and well-off individuals. Hence, forest land is becoming a base of capital accumulation for households that have access to political power and social networks (ADB 2001:12). Kinh migrants and members of other influential ethnic groups tend to benefit more from land allocation in contrast with poorer ethnic minorities living in more remote areas (Pham Duc Tuan 1999:234-238). It is common that Kinh people living in district towns and commune centers are in a better position to benefit from the land allocation program (including both forest and non-forest land) than ethnic minorities living in remote watersheds. In Lao Cai province, the people who have not been allocated forest land for forest gardens are the Hmong and the Dzao ethnic minorities (Vu Huu Tuynh 2000: 3). A study in four mountainous districts of Quang Ninh province found that poor capacity of forestry personnel and self-interested behavior on the part of local authorities in the process of forest land allocation resulted in inequitable distribution (Le Thi Phi et al. 2003:66). In Quang Ngai, respondents in a participatory poverty assessment said the poor tended to be excluded from the process of forest land allocation, and that they are now excluded from areas that used to be considered common property (ADB et al. 2003:67). Observations by researchers at the Centre for Resource, Environment Studies in Vietnam (CRES) showed that while seven households had plots under 0.5 hectares, three households had gained control of 80 hectares, which they were operating as an integrated farm enterprise generating good incomes (Le Trong Cuc and Rambo 2001:68). The poorer farmers often end up being given low quality or distant land. The area of land for perennial trees of better-off households is six times the area of poor households (World Bank in Vietnam, Oxfam GB and DFID 1999:8). A MARD document acknowledges that “... land allocation may ... marginalize vulnerable groups and individuals by excluding land use arrangements that are the basis of traditional systems, particularly among the ethnic minorities in the upland areas" (MARD/ICD 2001:52).

Some documents reviewed point out that the extent of social differentiation between the richer and the poorer households has increased due to forest land allocation (CRES and Ford Foundation 1999:45; Huynh Thu Ba 1998:30; Hobley et al. 1998:12). Those with capital and stronger social connections have gained control over large tracts of hill land while more disadvantaged households have obtained much smaller plots or lost out entirely (Le Trong Cuc et al.1996:73).

A similar situation is encountered in many of the villages of Lao Cai, Yen Bai, Ha Giang and Tuyen Quang provinces. Growing wealth disparities have negative effects. Poor households of the Muong ethnic group in Lang Beo village tend to give up land use rights on a temporary basis and become wage earners for wealthier families. They hope to make enough cash to buy the land back and invest in better land management. It is nearly impossible for these poor households to re-acquire the land due to the amount of compensation required to pay for the perennial crops being grown by the new land owners (Carr 1998:227-247).

The importance of equity in FLA is underscored by what could be achieved in 
poverty alleviation, even under the prevailing condition of population pressure. According to Donovan et al. (1997: 26), the area of hilly land, if distributed on an equitable basis, would be sufficient to give every household the land base on which to develop perennial tree crops such as tea, cinnamon, or citrus, or forest cover, to provide a sustainable source of cash income.

\section{(4) Geographic and logistical issues}

According to recent reports on land allocation, a variety of obstacles have beset the forest land allocation process in Vietnam including difficult terrain, few upto-date land-use maps, unclear boundaries between different land categories, and difficulties in reconciling the law with customary land-use practices (Tran Ngoc Thanh 2000a:13; Doan Diem 1998:4). In general terms, the FLA did not produce the rapid productivity improvements seen in agriculture (Sikor 1998:30). Government representatives constantly express concern about the fact that, in spite of progress in forest land allocation, forests are used but are not necessarily in the custody of a "real owner" (i.e., a legal entity) because of open access conditions. Forest land that has been allocated to households is often infertile and without financial and technical support from the government. Under these conditions, it is extremely difficult for farmers to engage in long-term forestry and to make a living from it (Doan Diem 1998: 6). In some villages, no family wanted the forest land that had been set aside for allocation because it was just too distant from their hamlets and would be too difficult to manage and protect (Le Trong Cuc 1997:51). Farmers allocated forest land that is far away from their homes often rent it out to SFEs with the fee as low as the land use tax (Vu Huu Tuynh 2001:38).

\section{(5) Policy errors}

Various policy errors have undermined implementation of the FLA program. One important problem, pointed out by MARD itself, is that the FLA does not permit joint ownership at the household and community levels, which tends to limit the rights of women and to undermine upland production systems that are based on joint property approaches (MARD/ICD 2001:53). One problem that hampers the development of household forestry is the local government's frequent shifts in socioeconomic goals, resulting in changes of tree species or crops (Huynh Thu Ba et al. 2002:24). At the provincial level, reports reveal that forest land-use changes take place fairly regularly and this does not allow households to adjust their own plans to cope with the sudden changes. As a result, land is left unused or used for different purposes. In Vietnam, only 20-30 percent of the land areas allocated have been developed following the government's land use plan (Morrison and Dubois 1998:35). ${ }^{19}$ In some remote upland areas, farmers were reported to have cleared the allocated forest areas for short-term profits, often due to tenure anxiety linked to frequent policy change or their ignorance of existing policies (Nguyen Ngoc Lung 2001:49).

Inadequate public education and extension undermines the FLA program. For example, better-off people tend to quickly take advantage of the issued land use certificates (Red Books) as a vehicle to access bank credits for economic development activities, whereas by the time poorer ethnic minorities learn how the system works, the opportunity for land allocation may already have passed (Huynh Thu Ba et al. 2002:29). In Ha Giang and Yen Bai provinces, many households were allocated barren or highly degraded forest lands and were given no extension advice on how to plant trees at those sites (Hobley et al. 1998:12). 
In Hue province, official district statistics showed that after three years of forest land allocation, the number of swidden cultivators seemed to increase. After receiving their land use certificate, none of the households in the surveyed commune invested in their allocated forest land due to lack of capital. Instead, they used it for grazing and collecting firewood. The households continued to depend heavily on swidden cultivation and collecting NTFPs (Le Quang Minh 1999:23).

In order to lift rural farmers out of poverty, the FLA alone is not sufficient. It is essential to reestablish forests and at the same time generate employment and diversify economic structures for mountainous area farmers while they are waiting for incomes from forest regrowth (Dao The Anh 1999:111). Land allocation can have significant impact in enhancing local people's livelihoods only if credit and technical assistance in agroforestry are provided to those with little or no savings (Vu Long et al 1996:19). It is also necessary to improve incentives (e.g., via benefit sharing systems) and markets for forest products. Tran Duc Vien (1999: 169) makes the case that forest land allocation can only have a positive impact in areas where there is already food security. If this is indeed the case, it suggests the need to better integrate FLA with other poverty alleviation policies.

Although this review of FLA presents a very mixed picture, there are promising recent policy developments that may enhance the potential for poverty alleviation through the allocation of forest land. New legislation to be passed in 2004 will create a legal foundation for community forestry. It will be possible to allocate land not just to individuals and households, but also to villages and hamlets. These changes, together with the implementation of Decision No. 178 on benefit sharing might substantially improve the possibilities for effective forest-based poverty alleviation in Vietnam. These will be discussed in greater detail later in this document.

\section{Timber}

To what extent has timber exploitation and production served the goal of poverty alleviation in Vietnam? Here we address benefits to poor people from small-scale logging of natural forests and small-scale production of plantation timber. In subsequent sections we will deal with the benefits of timber for industrial employment, for local multiplier effects, and for "trickle down" from national income.

\section{Small-scale logging of natural forests}

In brief, it can be said that there is very little information in the existing literature about this topic. Government institutions have not systematically documented smallscale logging income in Vietnam. This is because household-level logging is carried out in the "informal economy," with production and sales almost always being unregistered. The best we can do is piece together a rudimentary picture based on fragmentary knowledge. The same is true in piecing together an explanation of what the future benefits of small-scale logging might be.

Millions of hectares of timber have been felled in Vietnam in the last half century. As in other countries, the lion's share of this timber wealth has gone into the government treasury and to private entrepreneurs. Poor rural people have been excluded from direct access to this timber wealth largely because of the three following factors: (1) lack of capital necessary to buy the equipment and labor required for felling and transporting logs; (2) lack of local roads necessary for 


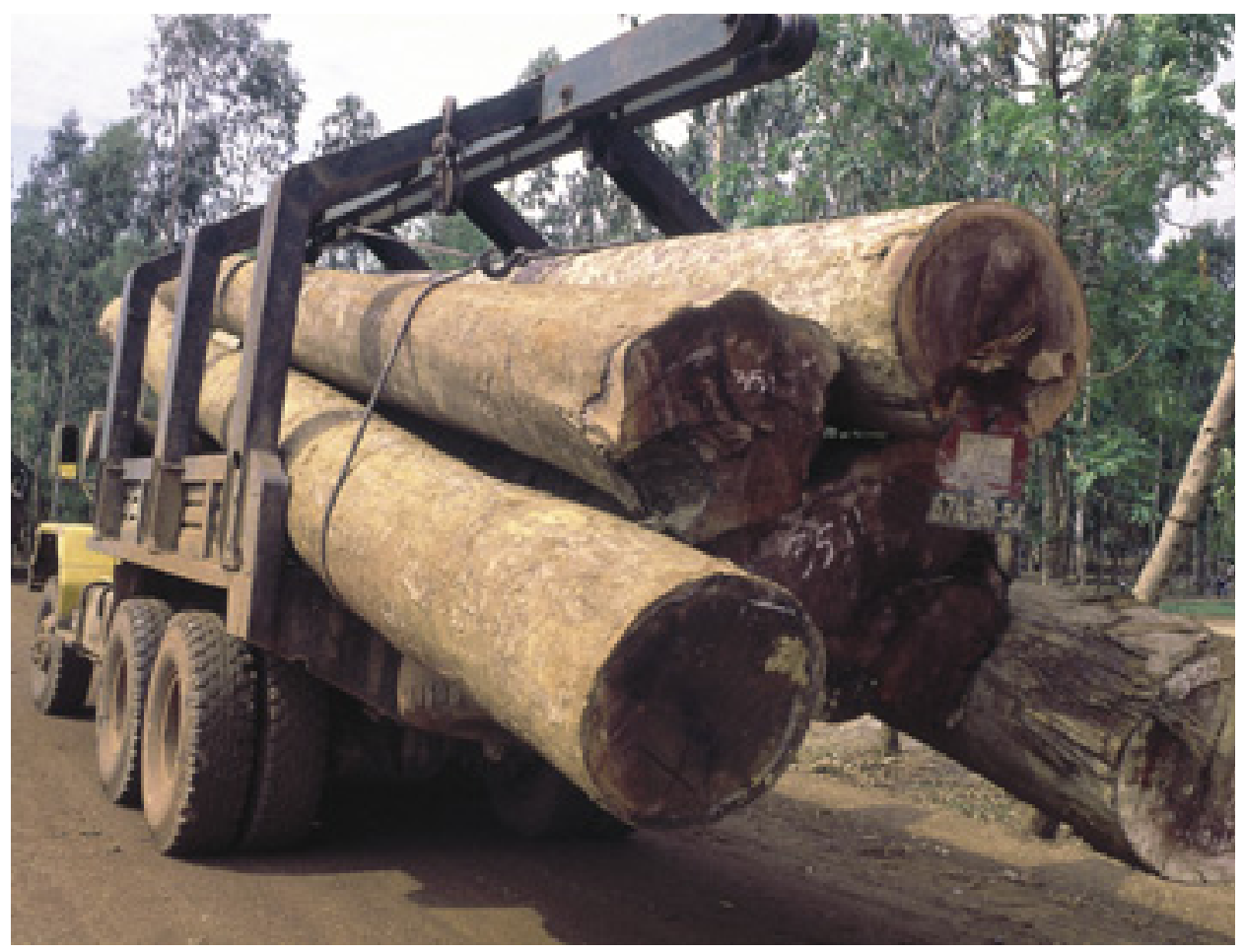

A Truck carrying logs (Photo by Christian Cossalter)

making timber accessible and transportable for marketing; and (3) enforcement of government prohibitions against small-scale logging.

Commercial-scale harvesting of timber is rarely seen as relevant to local people. The state or logging enterprises tend to see big trees as their own asset and not that of forest dwellers. At the beginning of the Resistance War against the French, the Vietnamese government restricted timber and NTFP exploitation in order to provide material for the war. Most forest products processing or trade activities during this time were stopped. For over a century, the uplands have been the primary source of raw material for the commercial timber industry. According to the book Lam Nghiep Vietnam 1945-2000 (Nguyen Van Dang 2001: 26) ethnic minorities suffered seriously from this prohibition.

In spite of historical obstacles to poor people's access to timber wealth, four recent developments have tended to create opportunities for small-scale logging. First, through the general improvement of economic conditions in Vietnam, smallscale logging equipment such as chainsaws is now more accessible than before to people in the lower strata of rural society. Second, the building of roads in remote rural areas has (often inadvertently) created the means by which otherwise inaccessible timber has become transportable and marketable. Third, there has been a booming demand for remote timber because of the elimination of more accessible timber stands. Fourth, external illegal loggers often need local collaborators and sometimes subcontract their work to local loggers.

Due to rapid forest cover loss and the exhaustion of timber supplies, the government imposed a series of logging and export bans beginning in 1990 (Lang 2001:119). Before 1999, there were 412 State Forest Enterprises holding logging 
quotas covering 3.5 million hectares of forest land and harvesting as much as 3.5 million cubic meters annually in the peak year (World Bank 2002). The government drastically reduced the annual harvest to about 0.3 million cubic meters in 1998 (MARD 2001a). In spite of this radical restriction on the allowable timber harvest, the amount of illegal logging is in the range of 0.5 to 2.0 million cubic meters per year (World Bank 2002). The closing of most SFEs' extraction quotas reduced incentives for appropriate forest management and has contributed to a situation where market demand is fulfilled in part by illegal timber extraction. ${ }^{20}$

There is no available information indicating how much of this illegal logging activity is small-scale, and how much of that small-scale activity might be alleviating poverty. Data gathered by the Social Forestry Development Program show that approximately 30 to 40 percent of the households in their surveyed areas in Song Da Watershed (northwest Vietnam) cut timber from the forest (SFDP 1994). This is consistent with estimates produced in another study (ADB 2000:14). One study says it is common in remote areas for local people to hire labor to harvest timber and to deliver the wood to roadsides for sale and that these labor payments cut significantly into their profits (Rambo et al. 1998: 45-49).

Various studies give basic insights on the nature of small-scale logging within the context of illegal logging. One study says that logging is sometimes carried out preemptively by villagers in anticipation of local logging by SFEs or other outsiders (Cao Thi Ly 2001:34). Indigenous people in the Central Highlands are sometimes hired by professional loggers to identify stands of timber suitable for felling (Huynh Thu $\mathrm{Ba}$ 1998:67). Some who participate in this activity prosper and are able to become loggers themselves (Huynh Thu Ba 1998:70). However, many others, in spite of spending years working for outside timber traders in the vicinity of the Pu Mat Nature Reserve buffer zone were not able to earn enough income to become traders themselves (Dao Trong Hung 1998:43). Some researchers have expressed concern that the gap between wealthier and poorer households may grow when the betteroff households are able to harvest timber from their forest lands (Tran Van Con and Nguyen Van Doan 2000:23; Sowerwine et al. 1998:85).

\section{Small-scale production of plantation timber}

Although the available literature contains little guidance on whether forestry employment can be a meaningful route to poverty alleviation in Vietnam, the following information-focusing on farmers producing plantation timber for pulp and paper mills-might be useful in piecing together a preliminary picture of overall possibilities. We focus on small-scale production of plantation timber because it is one of the key elements in the 5MHRP's plan to produce important livelihood gains in rural Vietnam. Through the 5MHRP, 2,000,000 hectares of wood-producing forests will be established as well as 1,000,000 hectares of other tree species including fruit orchards (MARD/DFD 2001:7). The government has approved the allocation of 364,000 hectares of forestry land in six northern upland and midland provinces for paper production (MARD 2001b:45). One of the main reasons for this additional production forest land will be to supply a booming paper industry, propelled by a nearly 10 percent annual growth in the consumption of paper. In 1995 the total production of paper was 220,000 tons and annual consumption of paper is expected to reach 1.2 millions tons by 2010. Approximately 6-8 million cubic meters of wood will be needed annually from new plantation forest lands to meet this demand 
(MARD/DFD 2001:6). It is expected that the establishment of additional production forests will contribute to rural employment and help alleviate poverty, though the 5MHRP does not specify the level of employment to be achieved (MARD/DFD 2001:78). One assessment claims that returns to labor in plantation forestry are larger for smallholders as compared to laborers in large enterprises, but these data are based on one case study and should therefore be considered preliminary and tentative (Jaakko Pöyry 2001:61-63, 71).

\section{Positive achievements}

Some documents record positive achievements by the plantations and paper sectors in providing livelihood gains. (Note that some of these achievements predate the 5MHRP.) In the Programme Alimentaire Mondial (PAM) reforestation program, implemented from 1978 through 2000 in 22 provinces throughout Vietnam, 450,000 hectares of forest lands were planted. Households received 500 kilograms of rice as a compensation for planting one hectare of forest. ${ }^{21}$ The forest planters were entitled to harvest all products from the planted forests and had to pay a land use tax (4 percent of the value of the total products harvested). This program created incomes for households from selling timber and, as acknowledged by provincial authorities, contributed to poverty reduction (Nguyen Ngoc Binh 1998:144-154).

In the past, the only raw material suppliers for the Bai Bang paper mill was state owned enterprises. In the period 1991-1996, the mill started signing timber supply contracts with individuals and with both state and private organizations in Yen Bai and Tuyeng Quang provinces. Forest planters seem to have benefited from this change towards a more open market-oriented mechanism (Vu Long 1998:80).

In a national workshop on forest plantations, the Vinh Phu Paper Enterprise management board affirmed that timber plantations to supply material for paper production are the best way to reduce poverty, providing employment and improvement in socioeconomic conditions in mountainous areas. According to the management board, apart from timber, local people are allowed to cultivate other short-term staple crops and collect twigs and branches for domestic fuelwood supply. The enterprise claimed that due to paper production, jobs for hundred thousands of people have been created, and incomes have been increased and livelihoods of people in the northern mountainous area have been enhanced (Khong Trong Ham 1998:154). ${ }^{22}$

\section{Problems and their reasons}

In spite of these glowing assessments for livelihoods improvement by the industry, there are references to many problems in the literature. Chief among the problems is very low returns to producers and a lack of incentives to participate in timber production. Here we document this problem and some of the explanations for this shortcoming.

The literature reviewed emphasizes the fact that although the demand for timber continues to increase, the price for timber from planted forests remains low (ADB 2001). According to To Dinh Mai and Vu Huu Tuynh (2000), although plantation forests contribute to solve the fuelwood and domestic construction timber shortages for farmers to a certain extent, forest planters have not yet benefited from selling forest products. They also concluded that forest planting has not yet been viewed as 
a profitable business even for people with secure land tenure and capital to invest in forest plantations. This conclusion may be open to question, however, because clearly some farmers have voluntarily planted trees to produce wood chips with little government support or encouragement. It may be a matter of geographical variation. Nevertheless, it is common knowledge that most benefits from planted forests come from trading and processing timber and that timber factories or intermediary companies, which buy and transport timber, appropriate a disproportionate share of the profits. Provincial wood collection monopsonies buy from smallholders and producers at very low prices, and charge high prices to wood processing enterprises (Artemiev 2003:13).

It is noted by researchers that although there are many stakeholders involved in the selling, buying and marketing of the raw materials for paper production, only forestry agencies and private enterprises invest in forest plantations (Do Nhuan 1998:73). The explanations for low returns and low incentives for small-scale timber planters can be classified under seven headings: (1) oversupply and weak demand; (2) too many intermediaries; (3) illegal logging; (4) inadequate knowledge; (5) biophysical disadvantages; (6) policy deficiencies; and (7) equity problems.

\section{(1) Oversupply and weak demand}

Various sources claim there has been a serious problem of oversupply of timber to the pulp and paper industries and this weak demand explains perpetually low prices and grave problems for smallholder suppliers. As we shall see, however, the issue of raw material supply is highly ambiguous.

After his assessment mission to the five northern mountainous provinces, $\mathrm{Vu}$ Huu Tuynh observed in 2001 that in the general vicinity of the Bai Bang paper mill the annual production of planted wood at harvesting age in the whole region was 420,000 tons, approximately 220,000 tons were surplus. The oversupply has greatly depressed prices. Due to the urgent need to meet household expenses, some forest planters sell their timber below the regulated floor price (Vu Huu Tuynh 2001:47). According to statistics of the Forestry Science Institute of Vietnam (Vu Long 1998: 83 ), in some SFEs the amount of timber in storage reached 30,000 cubic meters while at the paper mill there was 50,000 to 55,000 tons of paper in storage, twice the normal amount. This resulted in farmers being stuck with a large volume of wood, much of which rotted before reaching Bai Bang. Since the Bai Bang mill is the only consumer of wood for producing pulp in these areas, farmers were obliged to lower the price for their product. Economic analysis showed that after deducting the costs of extraction and transportation, forest planters suffered financial losses, especially those in remote areas (Vu Long 1998:85).

In his report titled The Pulp Invasion: The International Pulp and Paper Industry in the Mekong Region, Lang (2002) comments on the problem of 18,000 tons of paper being stockpiled by the Vietnam National Paper Corporation because of low consumption and on the problem of farmers selling their timber as firewood in local markets rather than to the pulp and paper industry because of lack of transportation and the "low economic value of these long-lasting trees." Lang (Nhan Dan 1 December 1999 cited in Lang 2002:100) explains that "While these examples do not give the whole picture, they do indicate that a further one million hectares of plantations to supply the pulp industry would not necessarily benefit either the pulp and paper industry or the farmers on whose land the trees are grown..." He says that unless the problems faced by the plantation industry are dealt with, "the expansion of the 
pulp and paper industry will make little sense" (Lang 2002:100-101). Among the key problems in the Vietnamese plantation industry identified by Lang (2002:99) are the following:

- Use of low quality soils for plantations as better soils are used either for higher value crops or for growing food;

- Low timber growth rates in Vietnam as compared with those in Indonesia or Malaysia;

- Scarcity of land available for plantations because of high population density;

- Dispersal of plantation parcels, which increases the costs of harvesting and transport;

- The climate for fast-growing trees is not as good in the north as it is in the south, yet in the south, most land suitable for plantation development is already in use;

- Frequent loss of plantation timber due to theft and to damage by animals and fire;

- Labor costs are low, but productivity is also low, and the costs of establishing and maintaining plantations are as expensive as elsewhere in the region;

- Road infrastructure is poor; and

- Port capacities limit the size of chip carriers that can be used.

A 1998 article in the Vietnam Economic Times explained that "In September 1998, Vietnam had more wood than the country's pulp processors could handle." The article argues that the rate of planting trees is not being matched by an increase in pulp processing capacity. Suppliers are stockpiling their timber while they wait for pulp producers to take their wood. Meanwhile, the industry is having to import pulp to keep the paper machines running, because the pulp sector is not producing enough. The article argues that MARD has boosted tree planting, wood production and the capacity of paper producers without increasing pulp production. The article concludes, "The biggest losers, as usual, are the farmers, who are either stockpiling or selling their wood at rock-bottom prices" (VET [1998] cited in Lang 2002:99).

At the regional level, there is a serious problem of over-supply of pulp and paper. Vietnam cannot compete with abundant, under-priced regional gluts in pulp and paper, mainly from Indonesia. Vietnam has not been particularly responsive to market signals for wood-based products and has largely ignored signals that suggest a move out of pulp and paper toward higher value, long-rotation wood products. ${ }^{23}$

Yet in spite of these observations about oversupply, there are some reports of shortages. In a 1996 report, Lang (1996:3) describes serious raw material supply shortages at Bai Bang and the reasons for them. He describes shortages at Bai Bang in the late 1990s that were aggravated by the opening of a wood chip mill in Hai Phong that paid higher prices to producers than Bai Bang paid. After 18 months the wood chip mill closed for lack of raw materials (Lang 2002:97). The Saigon Times reported in August 2001 that annually the industry experiences a 189,000-ton shortage of pulp and recycled paper each year, and relies on imports to fill the gap (Saigon Times 29 August 2001 cited in Lang 2002:99). It is not clear to what extent these reported shortages are location- and product-specific and to what extent they might reflect poor information gathering and knowledge about the overall supply situation.

Other issues related to supply are the following. Plans for encouraging the cultivation of some valuable timber species tend to be launched without previous extensive site-specific trials and with little consultation with farmers. Sometimes 
cultivation is promoted but without previous market scouting, thus resulting in oversupply and weak demand (Nguyen Van Tiem 1998:90). And while it is true that increased productivity of forests means a commensurate increase in the production of NTFPs, and thus an increase in farmers' harvesting income, NTFPs found in plantation forests are reportedly limited and hardly offer sizable incomes (Sowerwine et al. 1998:73-84).

\section{(2) Too many intermediaries}

The trade in plantation timber involves too many intermediaries and is often conducted under monopoly conditions either at the provincial or national levels. Farmers are forced to accept low prices and the incomes become negligible, making it impossible to accumulate sufficient capital to continue reforestation (Ngo Thi Minh Hang, 1996:2).

\section{(3) Illegal logging}

Planted forests for paper material have been illegally encroached and harvested. A massive amount of illegal logging occurred in the 1990s in forests planted to supply paper mills. Most of the illegally logged forests were immature (Le Duy Nguyen 1998:159). The demand for raw materials to feed the paper mills has also led to large-scale encroachment into natural forests. It was reported that in the 10 years since the Bai Bang mill was completed, more than 80,000 hectares of mostly natural forest were cleared to supply the mill (Le Thac Can et al. 1993).

\section{(4) Inadequate knowledge}

Researchers found that many forest dependent communities are not familiar with the concept of considering a forest plantation as a viable business (Vu Long 1998; Ngo Thi Minh Hang 1996:18). It seems that markets for timber and forest products have not yet been studied adequately. Forest planters suffer from a lack of information on how to generate revenue and greater benefits from forest plantations (Le Duy Nguyen 1998:162).

In some cases, farmers suffer from inadequate fore-knowledge of the consequences of participating in plantation forestry. Many households learned only after signing afforestation contracts that the stipulated tree species can shade out their food crops. As a result, the seedlings of these species were allowed to die and the farmers failed to receive any income from their planting activities. Other households, which continued growing these tree species, cleared other forest lands to grow their food crops (Tran Huu Nghi et al. 1999:12).

\section{(5) Biophysical disadvantages}

One of the key "anti-poor" characteristics of timber is that producers must wait for years to get a return on their investment: the poorer the producer, the less the ability to wait. It was found that the return from planted timber trees cannot compare with many shorter-term crops-even with bamboo. Unless farmers get paid for doing so, there is ample evidence that small farmers in Vietnam are reluctant to consider forestry production and protection (as opposed to food crops), especially if they do not have food security (ADB 2001:61).

Plantations of rare and precious tree species can take up to 70 years before harvesting. Currently, planters are paid to grow these species, but are not entitled to the harvest value of mature indigenous trees. In view of the low returns and 
the exceedingly long period before returns can be realized, some researchers have recommended that policies be changed to allow farmers to get a larger share of the value of such species (Vu Huu Tuynh 2001:36; To Dinh Mai 2001:44).

Other biophysical problems involve the choice of species and species hardiness. Some producers claimed that eucalypts grown in agroforestry systems reduce soil fertility, lower the water table, and give rise to pest problems (Sowerwine et al. 1998:87). Assessments made of forest plantation programs showed that there is a low survival rate of indigenous tree species due to the low quality of some soils, uncontrolled grazing, and lack of care by planters (Vu Huu Tuynh 2001:14). In theory, the government provides seedlings and technical assistance throughout the process of growing trees. Farmers are required to look after the trees and if the trees die, they are expected to pay the costs for seedlings. Farmers often voiced their concerns over the poor quality of the seedlings provided. In addition, it is assumed there is little scope for households to increase their incomes by producing tree seeds and seedlings except for some high value medicinal plants (FSIV 2002:24).

\section{(6) Policy problems}

The literature reveals that since benefits and responsibility-sharing for outsourced timber are not clear and because of the low survival rate of planted trees, farmers fail to receive significant incomes from forest plantations (Vu Huu Tuynh 2001: 45; Fortech 1998:3). In Vietnam, the definition and benefits of a "real forest owner" have been the subject of ongoing discussions at the national level for a long time. Unresolved issues include the forest owners' decision-making power related to production, extraction, transportation, and circulation as well as the consumption of forest products. In Hue province, it was found that many households do not want to invest in forest lands because they can be claimed by the State for forest plantations with short notice (Nguyen Ngoc Lung 2001:49).

Some reports criticized the approach taken by policy makers and planners towards forestry. Although harvests in forest plantations involve a much longer planning horizon than in agriculture, forestry planning is often conducted in the same manner as in agriculture (Friederichsen and Heidhues 2000; Le Van Vien 2000:12-13).

Lastly, the 5MHRP tends to assume that "bare lands" are often suitable for reforestation when this is not necessarily the case. For example in the Central Coast Region, 1.16 million hectares are classified as bare lands, but of this area only 180,000 hectares are deemed available and suitable for intensive plantation development (Jaako Pöyry 2001:xi).

\section{(7) Equity problems}

In many cases, income generation from forestry is limited and at best complementary to income from agricultural activities. There is clear evidence that richer households dominate the cultivation of tree crops (Luong Van Tien 1998:181).

Farmers' incomes from planting timber for paper production depend very much on a flat buying-rate fixed by the paper mill. This price is regulated to account for 67 to 81 percent of the final buying price at the paper mill. Forest planters earn only 50 to 55 percent of the fixed rate. This fixed rate imposes disadvantages on forest planters in more remote areas since they pay a higher price for transportation. Incomes from planting eucalyptus are as low as practicing swidden cultivation on infertile hill lands (Vu Long 1998:14). 


\section{Government efforts to improve small-scale production of plantation timber}

In an attempt to work with farmers on forest management, the government recognized the need for incentives for farmer participation and began to offer a wider variety of tree species. Although still limited by the availability of forest tree seeds, a greater effort is being made to provide villagers with seedlings of indigenous species. It is becoming clear that although the initial payments to farmers for plantation establishment expenses are useful, other issues regarding species choice, short term returns to farmers, and the integration of the management of bare lands into the wider agricultural and livelihood strategies of the villagers should also be taken into account (O’Reilly 2000).

\section{Future research}

Despite increasing demand for timber in Vietnam and the enormous potential economic benefits from forests, poor people appear to be reluctant to participate in the establishment of forest plantations. Researchers have made a few initial attempts to understand this quandary. Several reports contain information on annual and perennial crop (including tree species) budgets, but few provide reliable information on livelihoods and farming systems. Improved forest sector development and conservation clearly will require inter-disciplinary research approaches. Yet in many governmental forestry agencies there is a serious lack of adequately trained social scientists (Nguyen Van So 2001:2).

\section{Non-Timber Forest Products (NTFPs)}

NTFPs are important to the livelihoods of people in the remote uplands of Vietnam. These people tend to live near or in remaining stands of natural forests, and they rely heavily on fuelwood and on a variety of other NTFPs for food, fodder, medicines, construction materials, and other items. Some NTFPs are sold for supplementary household cash income or traded for essentials such as rice. It is estimated that 24 million people (approximately a third of the total population) living in or near forest lands, and nearly eight million ethnic minority people spend much of their time gathering forest products, hunting, and fishing (Poffenberger et al. 1998:9).

Reliance on NTFPs is especially common among ethnic minorities in Vietnam (ADB et al. 2003:67). Ethnic minorities tend to specialize in an array of NTFPs that are specific to the eco-regions they inhabit. For example the Dzao collect medicinal plants, cinnamon, and lacquer, the Hmong focus on high quality bamboo and rattan, and the Khmer in the south collect aromatic oil from melaleuca forests and other high value products from mangrove forests (Poffenberger et al. 1998:12-15).

Yet in spite of the clear importance of NTFPs in the livelihoods of millions of Vietnamese, there is as yet no national-level information that quantifies the contribution of NTFPs to household income, nor any reliable assessment of their role as a safety net, nor of their potential for lifting people out of poverty in a lasting way. Nevertheless-as in the case of small-scale timber-some (mainly case-study) research results can assist us in assembling a picture of the role of NTFPs in the lives of the rural poor. In this section we sketch this information in four theme areas: (1) the contribution to household income; (2) issues concerning demand and supply; (3) information on some key commodities; and (4) future possibilities. 


\section{The contribution to bousebold income}

Raintree et al. (1999:5) estimate that about 15 percent of total household income comes from NTFPs in Khang Ninh Commune. A case study in Luong Son district, Hoa Binh province by Pham Thi Xuan Mai et al. (1999:168) estimates that NTFPs account for 24 percent of total household income. However, as in the case of smallscale logging, substantial under-reporting of NFTP income may occur in areas where people rely on illegal collection of forest products. In the period 1989 to 1995, the value of NTFP exports from Vietnam was US\$ 40 million (Rosenthal 1998 as seen in Howard 1998:251).

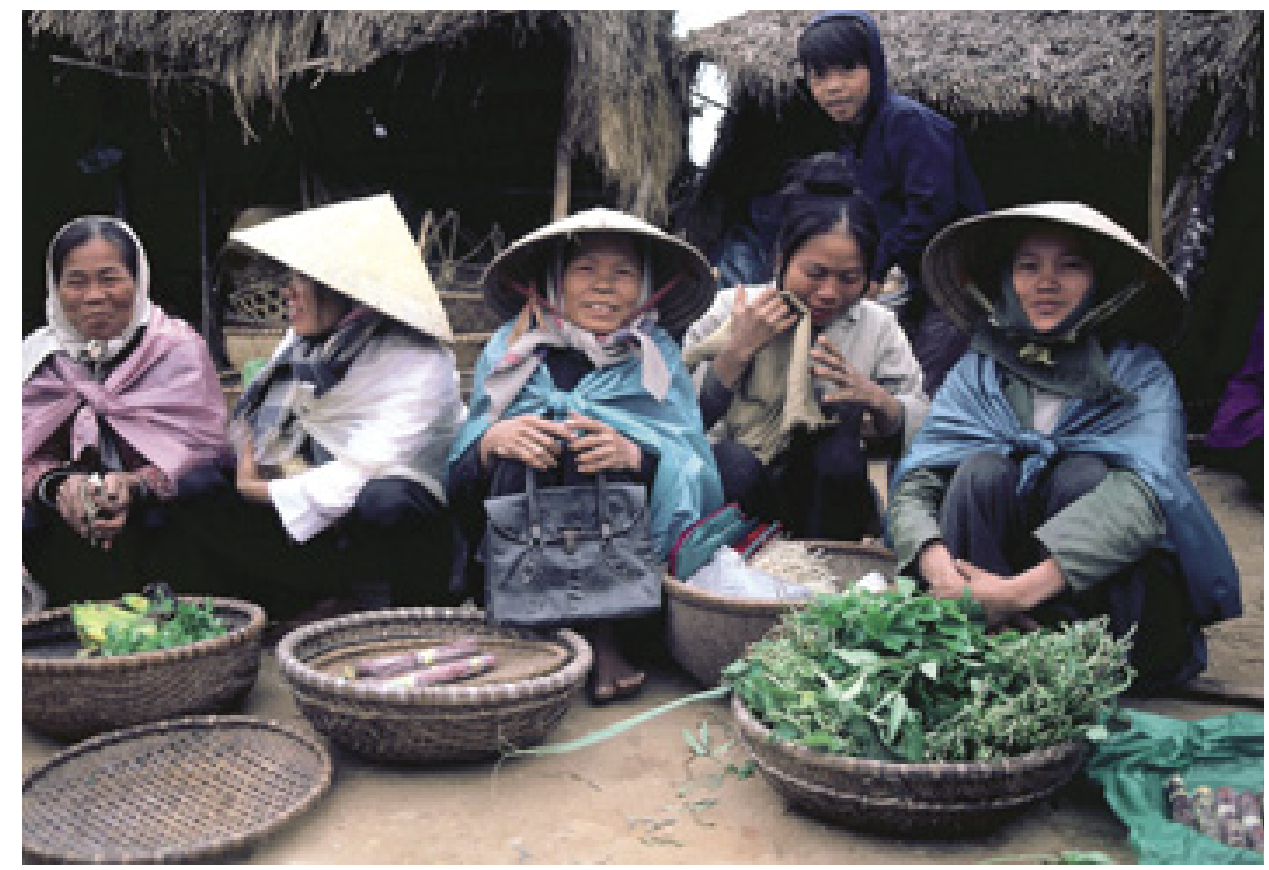

Women selling forest products and other goods in a market (Photo by Christian Cossalter)

NTFPs provide an important safety-net function through direct consumption and also through sales (Tran Van Bang 1999:34; MRDP 2000:42-50). However, in spite of the benefits they provide, NTFPs in some cases might not serve as adequate means for rising out of poverty. For example, one study focused on Hue and Quang Nam provinces shows that some poor people can be caught in a perpetual cycle of debt and forced to continue illegal hunting or other forms of NTFP extraction (Nguyen Quoc Dung and Vuong Duy Quang 1999:34-38).

\section{Demand and supply}

With the decline in logging due to the disappearance of old growth forests and the recent government restrictions on logging, some people have turned their attention increasingly to NTFPs (FSIV 2002:5). Various factors appear to have propelled increasing demand for NTFPs in remote areas of Vietnam. First, in the northern uplands, there is high demand for cross-border trade with China and this border 
trade has increased after the cessation of hostilities that took place in the late 1970s. For example, the market price of tortoise increased six-fold after the reopening of trade with China (Rambo 1997:40-45). The price of a bear's gall bladder is the equivalent of a year's income for an upland household (Jamieson et al. 1998:7). Second, the increasing cost of western medicines has made many Vietnamese turn to traditional medicines, which has increased demand for forest-based medicinals (Pham Chi Thanh et al. 1999:62-70).

It stands to reason that increasing demand for a wide variety of NTFPs would increase the incomes for those collecting and selling these products. While this may have happened in some cases, there are factors that tend to undermine the existing or future income-generating potential of NTFPs. One problem is that high demand has led to over-exploitation and restricted supply. There is documented evidence of fuelwood deficits in northern mountainous regions and in the central coastal area (McElwee 2001:8-9). There have been some high economic benefits from the trade in forest animals (e.g., Hoang Van Lam 2000:12), but a case study focused on the Phong Dien Nature Reserve documents the disappearance of the supply and income stream that used to exist (WWF 2000:14). Case studies conducted in Thua Thien Hue province also discovered a precipitous decline in the supply of NTFPs and income from this source (Le Trong Trai et al. 2002:7). Some studies claim that the largely illegal border trade with China poses a significant threat to the environment (WWF 2000:3; Blazeby et al. 1999:7). Another problem is that competition in high-value NTFPs tends to involve domination by elites and exclusion of the poor. For example the Social Forestry Development Program contends that the income-generating potential from forest medicinals tends to be limited because knowledge of medicinal plants is monopolized by few people who do not want to share their knowledge (Bien Quang Tu 2000).

\section{Important commodities}

Fuelwood, bamboo shoots (as well as bamboo) and other forest foods, rattan, wildlife and medicinals appear to be the key NTFP commodities in Vietnam. These commodities as well as other NTFPs are very important in livelihoods of rural households, particularly for the $\mathbf{8 . 5}$ million ethnic minority people living in the uplands (FSIV 2002a:1).

Fuelwood is overall the most important NTFP in economic terms, accounting for on average two-thirds of household income from NTFPs (Raintree et al. 1999:6). Rural Vietnam is still very dependent on fuelwood for heating and cooking. A 1992 study by FAO showed that biomass accounted for 60-70 percent of total primary energy consumption in Vietnam, and fuelwood was 30-40 percent of this total (McElwee 2001:7).

Bamboo shoots are a primary source of income and of supplementary food in fooddeficit areas of the northern mountainous region. This source of food is especially important for helping to meet dietary shortfalls during the pre-harvest seasons (Tran Duc Vien 1997). It is widely acknowledged that forest vegetables are on the daily menu of people living near forests. Although other vegetables and herbs can be grown in home gardens, some farmers claimed they can live without wild meat but not vegetables from forests (Nguyen Thi Cach 1999:209).

Historically, medicinal plants have been an integral part of both the health care system and the economy of many ethnic minorities in Vietnam. Examples include the Dzao people, who specialize in collecting, processing and prescribing medicines 
based almost entirely on forest-derived vegetation. The Dzao traditional medical healers in Yen Son village (Vinh Phu province) use over 200 species of herbs, shrubs, and trees. Nearly 80 percent of households in this village are engaged in traditional medical activities. Some practitioners earn as much as US\$270-450 annually (Sowerwine et al. 1998:80). Liberalization of the market economy and increased access to markets have enhanced traditional medical practices in some places. Some ethnic minorities have expanded their ethno-medical business by domesticating medicinal plant species in their gardens, processing and preparing prescriptions, and traveling far to treat clients.

\section{Future possibilities}

Views differ widely on the future potential of NTFPs for supporting rural livelihoods in Vietnam. Some sources say there is still much untapped potential for sustainable livelihoods through the systematic development of NTFPs (Pham Chi Thanh et al, 1999:67; FSIV 2002:5-51). However the SFDP claims that the income generating potential from NTFPs is over-estimated by researchers (Lecup and Bien Quang Tu 2000). Jamieson and his colleagues argue that hunting, gathering, and fishing have provided important supplementary sources of nutrition and income but can no longer meet the needs of a growing population (Jamieson et al. 1998). Other researchers confirmed that NTFPs have indeed been declining in importance as an income source, either due to the depletion of resources or the increased efficiency of forest protection laws (Hoang The Khang 2000:34; Phan Thu Huyen 1998:23-30; Nguyen Quang Duc et al. 1996:34). According to Rambo (1997:44), in most areas of the northern mountains, the once-rich wildlife has been so decimated by over-hunting and habitat destruction that it is no longer an economically significant resource. This diverse set of views among experts on the livelihood-supporting potential of NTFPs underscores the great need for additional research.

\section{Payments for environmental services}

It is clear that payments for environmental services have made a contribution to rural livelihoods in Vietnam, but the size and scope of that contribution has not been researched and is largely unknown. As such, we are unable to give attention to the important topic of direct benefits of environmental services to people living in forested areas in Vietnam. In this section, we restrict our attention to payments for environmental services and the benefits of those programs to rural people. We synthesize some of the evidence available in connection with two program: (1) Forest Protection Contracts (FPCs); and (2) Integrated Conservation and Development Projects (ICDPs). We give no information on eco-tourism and carbon sequestration schemes because these are at a preliminary stage of development in Vietnam.

\section{Forest Protection Contracts}

\section{Basic Information}

Payments for environmental services from forests have been carried out first through Program 327 (introduced in 1992), through Program 556 (1995), and then through the 5MHRP's Fund 661 (1998 to present) (see Box 1). Under the terms of the three programs, rural people have been offered cash incentives through Forest 
Protection Contracts (FPCs) to replant trees and to protect existing forests. FPCs aim to protect existing forests and to stimulate natural regeneration through payment to contracted parties of up to 50,000 VND (just over US\$3 at the current exchange rate) per hectare per year. FPC beneficiaries receive payments for planting, protecting, and regenerating forests on different types of forest lands including forested lands, non-forested lands, and lands planned for plantations and for regeneration. These land categories can be associated with special use forests, watershed protection forests, and mangrove protection forests. Beneficiaries are allowed to collect NTFPs and other forest products, though with some restrictions. Households, groups of households, and ethnic communities living in or near forests are the primary beneficiaries (MARD/DFD 2001:21).

\section{Box 1. Three programs related to the awarding of Forest Protection Contracts}

In 1992, the government introduced Program 327, aimed at "re-greening the barren hills." The original objectives of the program were to encourage replanting, protect forests, improve land utilization, raise living standards, and support the sedentarization program. Each household in the project area was provided with a defined area of land for reforestation, protection, enrichment and regeneration. Where possible, some land was also provided for grazing and production of food crops or cash crops.

In 1995, Program 556 was promulgated to refocus the activities of the Program 327. Program support was limited to protection and special use forests through plantation and agroforestry, mainly relying on farmers for implementation. Support for plantations of industrial crops, fruit trees, scattered trees around houses and fields, and resettlement was discontinued except where these were in protection and special use forests. The decision to refocus the 327 Program on protection areas and increasing farmers' involvement were major changes and limited government spending to areas where off-site benefits were more likely and would mobilize complementary farmer investment.

In 1998, Program 661 of the 5MHRP was introduced with the aim of increasing the area of "forest" in the country to 14.3 million hectares by the year 2010 . One source claims that most developments on the ground have essentially been a continuation of Program 327 (ADB 2001:2426), but arguably there are some important changes. Program 661 activities are wider in scope than those in Program 327 (involving reforestation, tree plantations, and watershed protection) and emphasize reforestation rather than afforestation.

In principle, the government encourages the poorest segments of forest dependent communities to participate. FPCs have become one of the most common forms of involvement of local people in the protection of forests in Vietnam, currently covering about 1.6 million hectares and involving 270,000 households (MARD 2001b:66).

One of the benefits of paying people to protect existing forests (as compared to paying them to plant trees) is the relatively high internal rate of return, depending on the initial conditions of the allocated forest-land plots, the associated benefit sharing system, and whether or not participating farmers receive compensation for their services. Experts believe that natural forest regeneration, by not entailing high costs, is one way to minimize farming risks (Apel 1997:7; Pham Van Viet 1998:5).

\section{Successes}

Some researchers making observations on specific sites have concluded that FPCs for special use or protection forests have contributed to poverty alleviation by providing cash for work (Nguyen Van Thang 2001:34; Dang Thi Hue 2000:13). A World Wide 
Fund for Nature (WWF) study in Hue and Quang Nam provinces claimed that FPCs in some areas have made visibly positive impacts on forest condition and on the local economy (Nguyen Quoc Dung 2002:67). Ngo Thi Phuong Anh and her colleagues found that a relatively high proportion of the annual income of the Ka Tu ethnic minority in Hue province comes from forest protection and management fees. Local Ka Tu people are allowed to harvest certain types of NTFPs from the forest, which generate around 10 million VND every year for the whole commune. Incomes from all forest-related activities accounted for 24 percent of the total household income (Ngo Thi Phuong Anh et al. 1999:148). The government views this amount of cash income as sufficient to encourage more people to participate in forest protection and management. In his recent assessment on the institutional renovation and management of SFEs in Quang Ngai province, Vu Huu Tuynh found that the households with FPCs each received between 1.5 to 2 million VND annually, equivalent to 1 to1.6 tons of rice, which has helped to ensure food security and to curb swidden cultivation. However, he concluded that, since the number of households engaged in forest protection and management is still small, FPCs do not have significant impact on poverty reduction in that province (Vu Huu Tuynh 2001:23).

\section{Problems}

In spite of these generally positive accomplishments, Program 327 received much criticism from international agencies, domestic researchers and even some government officials for its limited success in meeting its goals, for its top-down design, for low participation of local people in its implementation, and for promoting the planting of trees on land that is crucial for local food security (Sikor 1998:25). As explained by Fortech (1998:15-16):

\footnotetext{
The Government sees land in 327 project areas as plentiful, bare and unproductive. Local households view it differently. For them, land is scarce. Households adjacent to bare land establish and defend use rights over the bare areas. They will use as much of it as they can to grow food. If the land is unable to support food crops, they'll try cash crops such as rubber, coffee, tea or fruit trees. If these fail, the land will be used for grazing as cattle or buffalo can return annual income. Trees are generally the last option tried by local people because of the long wait for income....
}

Critical commentary on the implementation of FPCs can be clustered in six theme areas: (1) government control and restrictions on forest use; (2) low returns to participants and dependence on government; (3) inadequate funding; (4) corruption and bad practices; (5) ambiguity and complexity in the provisions of the program; and (6) inequity.

\section{(1) Government control and restrictions on forest use}

It was found that in some mountainous provinces, the over-restrictive conditions on forest resources (e.g., afforestation only or no harvesting for subsistence) have undermined the very purpose of the contract itself, thus leading to program failure (Vu Huu Tuynh 2001:34). In Phu Tho province, extraction of bamboo and rattan from forest gardens (now considered natural forest) is not allowed. In many areas, households are denied access to cut timber on allocated forest gardens that have regenerated into valuable timber species (Vu Huu Tuynh 2001:77; Tran Ngoc Thanh 2000b:20). Furthermore, regulations governing the extraction and use of forest 
products are too complicated and time consuming. Some NTFP specialists claim that the strict regulations on the extraction of both wood and non-wood products are unnecessary (Vu Huu Tuynh 2001:45).

\section{(2) Low returns to participants and dependence on government}

Literature on re-greening efforts in the coastal areas reveals that the program does not yield much in the way of sustainable income to families. MARD itself acknowledges that its policy on contracting of forests for protection "does not provide incentives for efficient protection by the contract holders... Income from contract payment of 50,000 VND per hectare per year for a household is insufficient to make them abstain from illegal (and very profitable) exploitation of forest resources" (MARD/ DFD 2001:36). ${ }^{24}$ Many fishing households refuse to participate in the program as they think the government's compensation for their time and effort is not sufficient (Phan Thi Anh Dao and Phan Nguyen Hong 1997:15). Another issue concerns who are the recipients of the future benefits from the forest plantations. Under the current system, 60 percent of the future returns go to the state and 40 percent to the households. Based on the provisions of Program 556 introduced in 1995, farmers can grow trees with a ratio of 40 percent indigenous and 60 percent other species (including industrial and fruit trees) in protection and special use forests. All indigenous trees will remain the property of the state, but the farmers can retain two-thirds of the value of the products from the other trees planted, all the products inter-cropped under the forest canopy, and any flowers and fruit. There is wide variability in the returns to farmers from participating in FPCs, not just because of the variability of the quality of the land on which the program is implemented, but also because of considerable variation in the interpretation of forestry laws among provinces. Generally speaking, because of low returns, some communities are not interested in maintaining the established plantations (ADB 2001:15). According to Carew-Reid et al. (1999:82):

Plantation development, even if successful, can provide some income but cannot match agricultural land uses in immediate returns. In fact in some regions, an over-supply of plantation timber, for example, eucalyptus poles is causing a reduction in market prices to the point where farmers risk making a loss, rather than the profit anticipated and calculated into the cost/benefit analyses of many projects.

Even in cases where the cash income obtained through the program is valued, there may be a negative outcome. In many areas, people value the contracted forest areas for the cash income provided through Program 327 and not for other possible benefits (To Dinh Mai 2001:89). Seedlings and other inputs provided under this program were viewed as grants from the government without real support (effective technology transfer and extension services) for promoting sustainable production systems. It seems that, on the one hand, incomes from protecting forests can contribute to poverty alleviation, yet on the other hand, it has undermined a sense of ownership of forest resources and has aggravated the mentality of relying on government cash for forest protection. Based on their review of the program in $\mathrm{Ha}$ Giang and Yen Bai provinces, Hobley et al. (1998:8) remark that: "The present practice of giving VND 50,000 per hectare for the protection of contracted land will not achieve the objective of increasing self-reliance and, therefore, should be phased out immediately before it creates chronic dependency among farmers." 


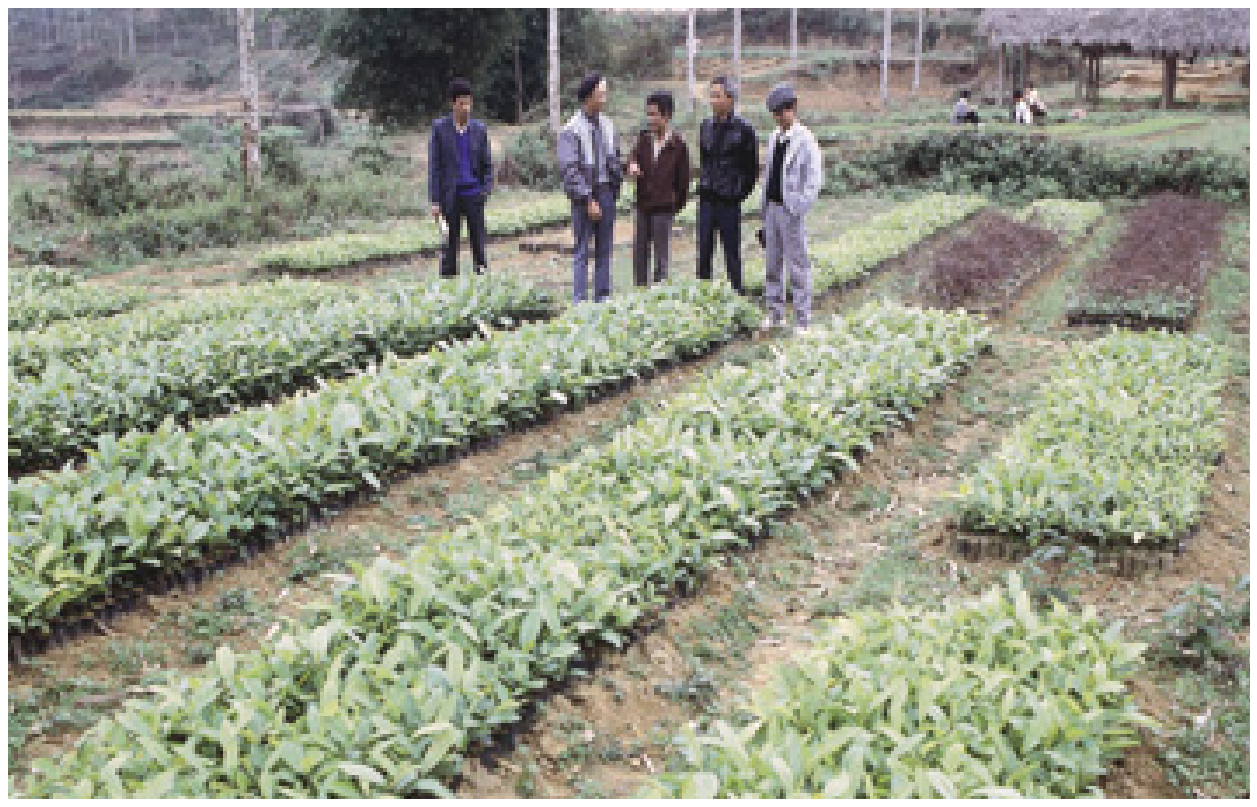

Nursery of native forest species (Photo by Christian Cossalter)

\section{(3) Inadequate funding}

Various donors and some policymakers claim that FPCs are not sustainable given the amount of cash required from the government annually to ensure quality and effectiveness. ${ }^{25}$ The government itself claimed the budget for Fund 661 was inadequate for effectively protecting large areas of forest (MARD/DFD 2001:36). One of the major problems of the program was a lack of funds to ensure the equal engagement of all ethnic minority households, which caused dissatisfaction among these communities (Dang Thi Hue 2000:22). Another major problem is that with inadequate monitoring and enforcement to assure that program goals were fulfilled, FPCs are perceived at the local level as a social subsidy rather than as an incentive for forest protection. ${ }^{26}$

\section{(4) Corruption and bad practices}

The government estimated that implementing agencies, including district authorities and SFEs, have diverted more than 50 percent of total funds of Program 327 for other purposes (Sikor 1998:56). There are cases in Daklak province where forest protection fees were debited without consultation to pay for taxes or fees that the households had failed to pay earlier (Huynh Thu Ba 1998:43).

\section{(5) Ambiguity and complexity in the provisions of the program}

Many documents discussing Program 327 mention the confusion experienced by participants because of ambiguity in the provisions of the program (Tran Van Con and Nguyen Van Doan 2000:39; ADB 2001:13). Generally speaking there tends to be a lack of understanding of the rights and obligations stated in the contracts (MDRP 2000b:15; Huynh Thu Ba 2002b:45). It is common for participating households to receive no official documentation and to remain uncertain about the boundaries of their plots and the benefits they can expect to accrue from managing them (Vuong Duy Quang 
2002:51). Research in Ha Giang and Yen Bai provinces showed that participants experienced considerable uncertainty about the flow of benefits. For example, they were not sure whether payments would be in cash or in kind and whether they would in fact be paid at all. Due to the shortness of contracts, they had little incentive to participate in the long term (Hobley et al. 1998:13). The dependence of participant households on the state for seedlings contributes to the uncertainty with regard to the real ownership of mature trees. Technical assistance and forestry extension service remains insufficient. Uncertainty persists regarding permission to harvest and the share households can receive (Hansworth 1999:67). The confusion resulting from differing perceptions between local people and government officials can lead to devastating situations at the time of timber harvest. Many farmers insist that the trees should belong to them despite what local officials say. On the basis of this belief, they sometimes cover large areas of land with forest and fruit trees, to the point of crowding out their staple food crops. The timber harvested in the end, however, may not wholly belong to them and generate the expected income. Hence, this situation can conceivably threaten food security (Nguyen Van Thang 1997:14). Some participants are requested to fulfill lengthy and complicated procedures for harvesting NTFPs. This has reduced the enthusiasm and participation of some people in forest planting and management and has undermined a potential source of income (Vu Huu Tuynh 2001:67). MARD itself acknowledges deficiencies in the formulation of Program 661 pointing out that "The mere quantification of jobs to be created ... will not address the qualitative aspects of employment such as worker's safety and health, non-discrimination, access to training programs, and the right to organize and collective bargaining" (MARD/ICD 2001:13).

\section{Inequity}

One of the unexpected effects of the re-greening program has been a widening of the gap between better-off and poor households. Better-off households are more readily included in the project due to the location of their plots of land (Vu Van Tuan et al. 1996:17). It is relatively common for households to be chosen to sign forest protection contracts based on personal connections (Nguyen Van Thang 2001:12). According to an evaluation of FPCs conducted by SFDP in Yen Chau district, participants from the Thai ethnic groups received payment for protecting forests while the Hmong villagers did not (Apel and Pham Van Viet 1997:4).

\section{Possibilities for improvement}

Some researchers (Vu Hoang Minh 2002; Nguyen Tuong Van 2002:11-15) have expressed optimism about the introduction of new regulations offering program participants a share in the value of forest products, in addition to the protection fee of 50,000 VND per hectare per year. It is expected these new regulations will attract more farmers to participate in forest management and protection while improving their living standard.

Forestry regulations are being implemented in different ways in different provinces. Some provinces are more flexible and progressive than others and can set up trial sites for community forestry before the central government legally acknowledges this form of forest management. An example of this is $\mathrm{Ha}$ Giang province, which implemented Decision 2430, an important tool in guiding implementation of national government policy on forest exploitation and benefit sharing. ${ }^{27}$ Furthermore, in a bold experiment, Daklak province has allocated natural 
forests to household groups and communities through pilot projects, even in the absence of a national level law enabling this form of forest use. It is important to bear in mind that FPCs were intended as a temporary solution to the problem of forest destruction, to be applied until such time that a better solution is found (Vu Hoai Minh and Warfvinge 2002:12).

\section{Integrated Conservation and Development Projects}

In Vietnam, internationally funded Integrated Conservation and Development Projects (ICDPs) began in the early 1990s. These projects have been carried out under several assumptions, including the de-linking of local people from dependence on forest resources in protected areas and offering alternatives. These projects often offer alternative livelihoods such as agroforestry, weaving, bee keeping, and mushroom and vegetable farming in an attempt to mitigate local people's impacts on forest resources.

Successful examples that could stimulate interest in conservation efforts include sizeable incomes and returns from mangrove afforestation in Ha Tinh and Tra Vinh provinces. At those sites, researchers have confirmed that a direct link exists between increased food security and improved forest management (Dau Thi Lien 1999:88-93).

There are more than 15 ongoing ICDPs in Vietnam (Nathan Sage and Nguyen $\mathrm{Cu}$ 2001:6). The performance of these projects is a matter of controversy. In the book Localized Poverty Reduction in Vietnam, researchers found that while conservation efforts need to be intensified, they do not directly offer an immediate reward to local people or a means for them to escape poverty (Hainsworth 1999:23). The authors conclude there is a need for research on how farmers in buffer zones of special use forests can maintain their livelihoods and yet improve the effectiveness of forest protection. It was also suggested that realistic intervention mechanisms cannot be put in place if the role and importance of forestry in rural livelihood systems is not properly assessed. It clearly would be useful to have these kinds of data for each of Vietnam's major agro-ecological zones (Hainsworth 1999).

\section{Employment}

In this section we focus our attention on people employed in the industrial forestry sector (e.g., as laborers in logging, transport, wood products manufacturing) and in the small-scale woodcrafts industries (e.g., producers of furniture or handicrafts). The aim in this section is to take account of those people deriving income from the forest sector who are not included in the other sections. "Industrial employees" by this definition excludes people clearing forest land for agriculture, people conducting their own small-scale logging operations in natural forests, small-scale producers of timber for plantations, people producing NTFPs of various kinds, and people benefiting from forest protection contracts.

A survey of national industries in Vietnam found that there were a total of 512,808 people working in forest-related industries in Vietnam in 1998. This figure is comprised of 315,400 people employed in the manufacture of wood products, 158,880 people employed in the manufacture of furniture, and 38,528 people employed in the production of paper and paper products (GSO 1999). ${ }^{28}$

Employment in SFEs is not directly synonymous with forest industry employment. Nevertheless, it is important to look at data on change in SFE employment over 


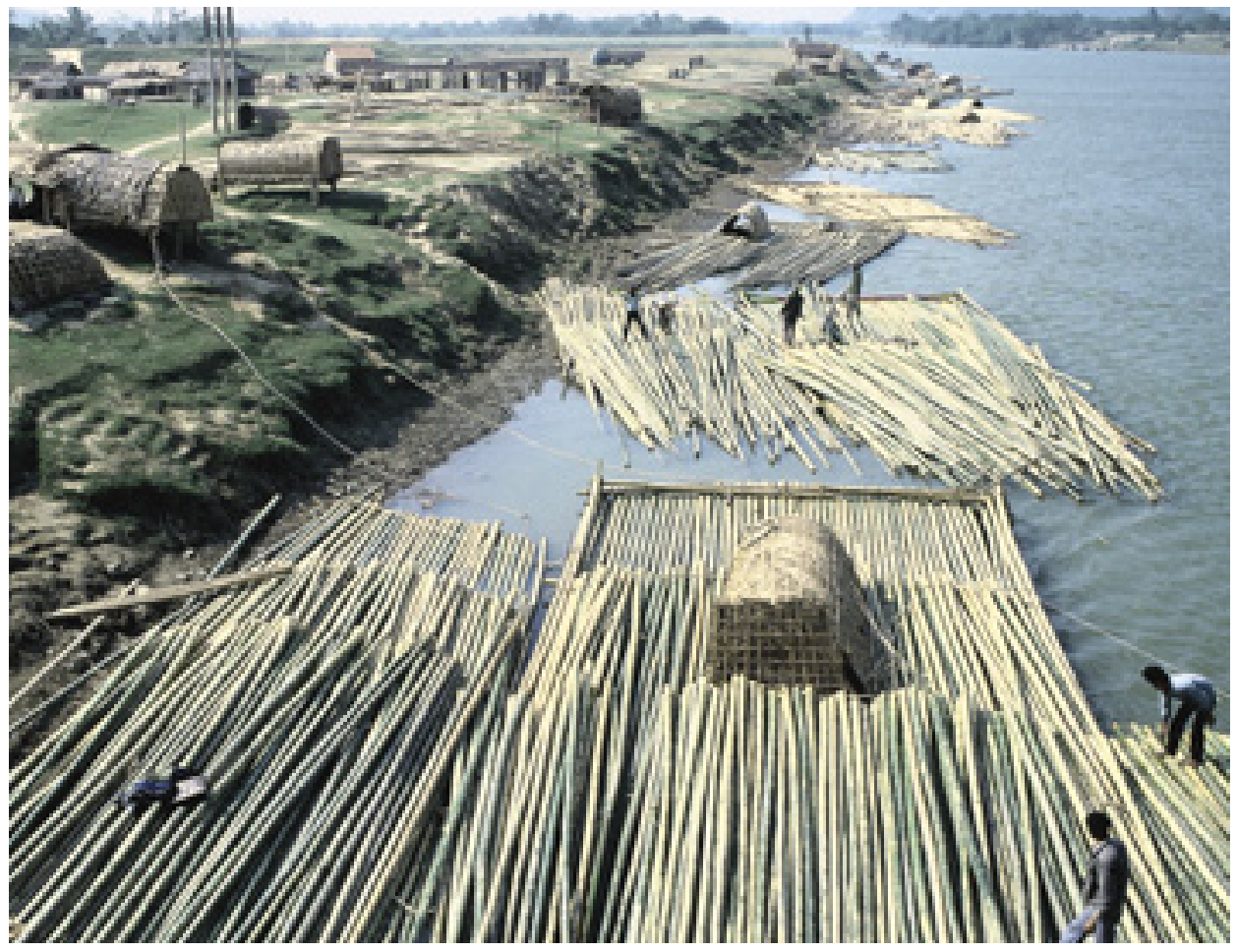

Bamboo poles being floated down a river (Photo by Christian Cossalter)

time. In the early 1990s, Doi Moi policies led to the transfer of SFEs to provincial authorities and resulting budget constraints led to massive reduction in employment. Permanent staff decreased from 220,000 to 28,000 , and seasonal workers from 180,000 to 27,000 , though these unemployment effects were offset by forest land allocation (Artemiev 2003:3). In the late 1990s, 28,800 people were employed by the SFEs (Ogle et al. 1999:3).

Little is known about the prospects for employment through the 5MHRP. One MARD document acknowledges that the 5MHRP has tended to focus on FPCs for employment provision but has given much less attention to forestry employment in secondary (harvesting and processing) and tertiary (services) sectors (MARD/ICD 2001:55).

Very little is known about the extent to which people may have risen out of poverty through their employment in the forestry sector in Vietnam because this topic appears not to have been researched. But this should not be surprising because this is the case in many countries throughout the world (FAO 2003b:66).

Even on the basis of inadequate information, one important point can be deduced. It is unlikely that the industrial forestry workforce would become a major path out of poverty because it is a relatively small fraction of the total labor force. It is unlikely that this would change, even given the most optimistic projections of success of the 5MHRP. But let us bear in mind that the industrial forestry workforce is by its nature relatively capital intensive and labor reducing, and that it is likely to be orders of magnitude smaller than non-industrial and informal forestry employment activities. 


\section{Indirect benefits}

In what ways have forest resources in Vietnam improved livelihoods through provision of indirect benefits? Earlier we specified that by indirect benefits we are referring to local multiplier effects (e.g., local employment and income opportunities related to the opening of logging concessions, the opening of logging roads and the creation of marketing opportunities, and compensation to communities in the vicinities of concessions) and trickle down in the sense of timber-generated national treasury revenues which are then spent at the local level for development purposes.

\section{Local multiplier effects}

Given the dominant role of State Forestry Enterprises in the history of logging in Vietnam, information on local multiplier effects must be sought in the literature on SFEs. Unfortunately, we were unable to find any documents that give any idea of the degree to which the presence of SFEs in communities might have generated local multiplier effects, and to what extent they might do so in the future. The only piece of information even remotely of interest is that in the 30-year period through 1999 , the forestry sector has participated in the construction of more than 10,000 kilometers of roads and the upgrading of 3,500 kilometers of roads, mainly in the mountainous areas (Nguyen Van San and Gilmour 1999:27). One can suppose that these roads have helped lift the socioeconomic status of area inhabitants, but there is no direct proof of this.

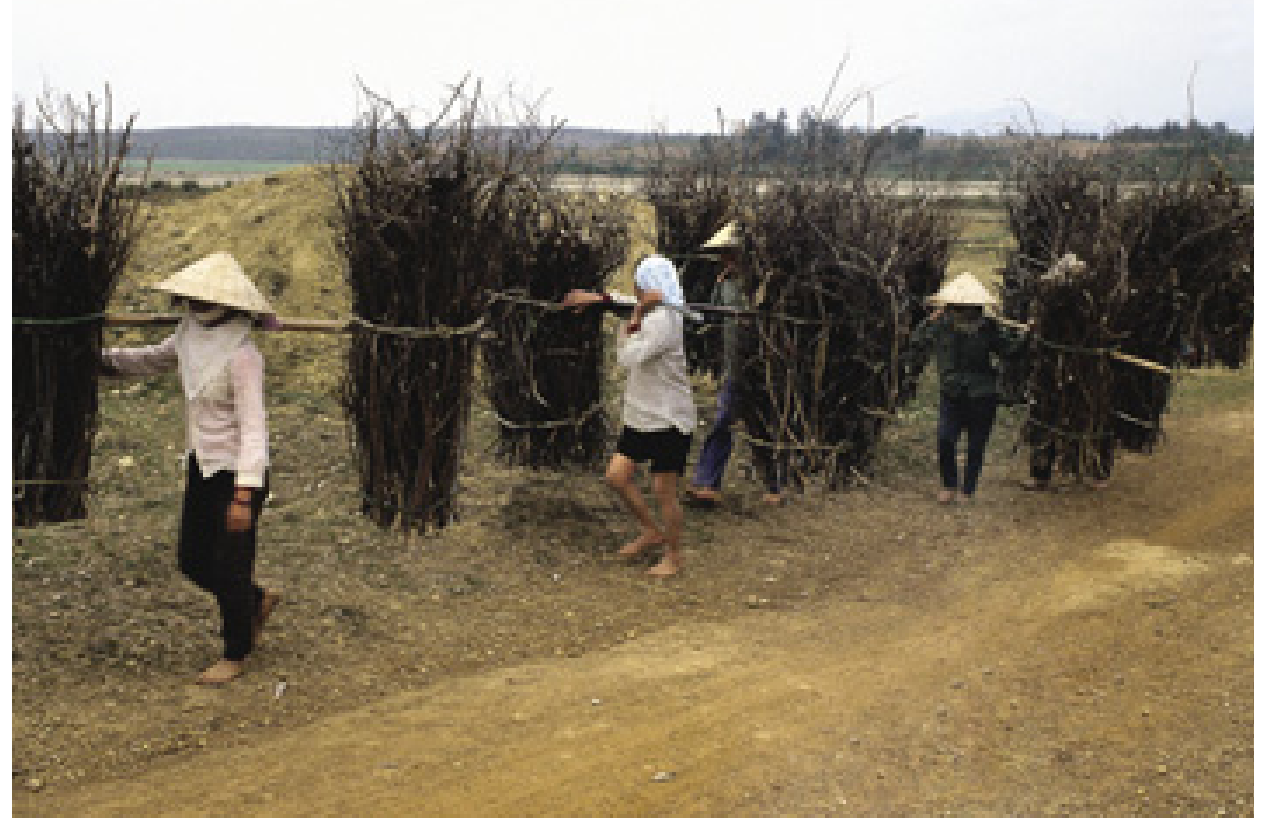

Transporting branches to be used as firewood (Photo by Christian Cossalter) 


\section{Trickle down}

The degree to which national level forestry income has contributed to increased standards of living and poverty alleviation is almost wholly undocumented and therefore a matter of speculation. Here we hypothesize the bare elements of an explanation based on the small amount of information available.

If we define national forestry income as broadly as possible and include in that definition the conversion of forest lands to agriculture then, undoubtedly, there has been a very substantial contribution from the forest sector to poverty alleviation via the macroeconomic channel. Increasing per capita income in rural Vietnam is closely tied to the transition from wholesale dependence on forest resources (hunting and gathering) to swidden cultivation and then to sedentary agriculture. This process, in turn, is closely related to the gradual elimination of forest cover in wide stretches of Vietnam.

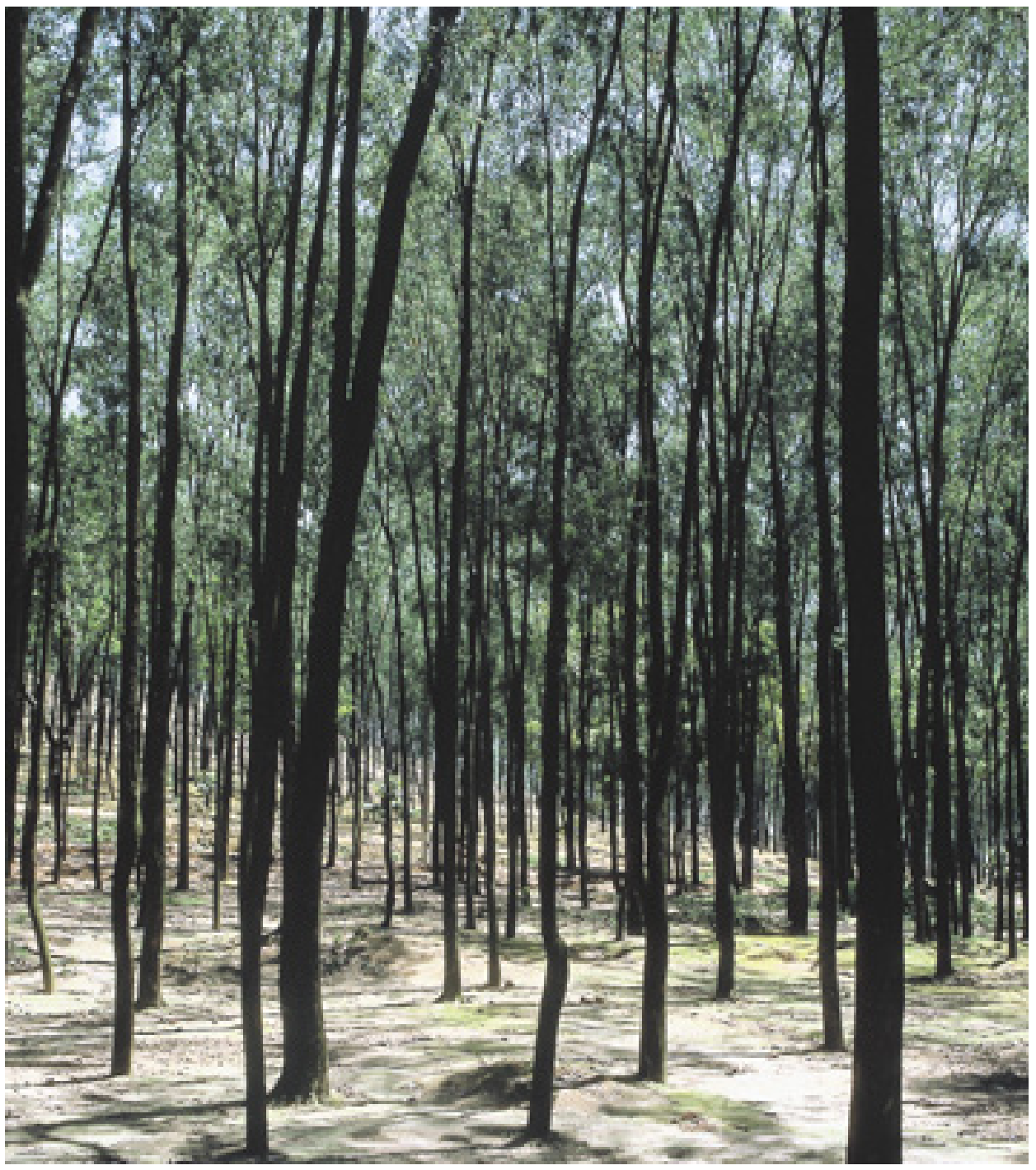

A forest in Vietnam (Photo by Christian Cossalter) 
If we define national forestry income more narrowly in terms of timber revenues, the level of the contribution is far less clear. Over the last half-century several million hectares of natural timber stands have been felled and a portion of the timber felled has been sold and has served as a base for national income, tax, and royalty revenue. How many millions of dollars this amounts to, how it was spent, and what effect this may have had on rural people is almost impossible to know. However the following pieces of information may help put the issue in perspective.

During the period of the War of Resistance against the French in the 1940s and 1950s, timber revenues were channeled to provincial-level treasuries rather than into reforestation. In 1949, the revenue from timber and NTFPs accounted for 70 percent of the total revenue in Ba Ria province, 50 percent of the total revenue of Bien Hoa province, and 25 percent of the total revenue of Tay Ninh province (Nguyen Van Dang 2001). Logging was intensified in northwestern Vietnam in the 1960 s and 1970 s to assist the government in paying for the war against the U.S. and to clear land to accommodate lowland settlers (Nguyen Van Dang 2001).

Observed in terms of the "big picture," timber has never been a very large national income earner. In the late 1990s, timber accounted for 1 percent of GDP, but this figure is closer to 4 percent if we include domestic wood processing, consumption of timber products and fuelwood, and the export of wood-based products (Poffenberger et al. 1998).

Prior to 1999, there were 412 SFEs holding logging quotas covering 3.5 million hectares of forest lands and harvesting some 3.5 million cubic meters of timber annually (World Bank 2002). SFEs were then marginally profitable, each earning on average 217 million VND (US\$17,000) annually in surplus revenues and paying an average of 448 million VND (US\$34,500) annually in taxes (Ogle et al. 1999:3). On the basis of this we can surmise that the annual tax income on timber was approximately US\$14 million. Vietnam is a "high tax environment" for timber production with most of annual profits going to the state. This made internal accumulation of circulating capital for expansion of SFEs difficult (Ogle et al. 1999:6). With the government's recent radical restrictions on timber logging, tax revenues based on SFE timber operations have been greatly reduced. Since then SFEs have been greatly dependent on revenues from Program 327 and its successor programs for their continued existence.

What are the prospects for generating large amounts of tax revenue and foreign exchange earnings in the aftermath of the logging ban? The 5MHRP has high expectations that plantation timber production will produce substantial revenues, though these are unspecified. In the northern mountains, it is unlikely that the pulpwood industry will generate profits on the same level as that obtained through past exploitation of timber (CRES 1998:45-49). Successfully reforesting millions of hectares of "barren lands" potentially provides the basis for substantial government revenues, but major uncertainties include the degree to which these lands can successfully be reforested, and of course, realization of adequate levels of forest product demand both domestically and on the export market. One report forecasts that Vietnam has a comparative advantage for future wood chip production and export to Japan provided that it is located in the Central Coastal Region, where it could take advantage of short haulage distances to existing and planned ports and the availability of a substantial area of "bare lands" (Jaakko Pöyry 2001:64-66). 


\section{New policies: Community forestry and benefit sharing}

Recent changes to the Land Law, passed by the National Assembly in October 2003 and to be enacted by decree in mid-2004, will allow the allocation of land (including forest land) to communities, not just to households. This means that larger tracts of land can be allocated to villages and hamlets in remote rural areas. This legal change, along with a new regulation on benefit sharing, will establish the legal basis for community forestry in Vietnam. Community forestry potentially increases the forest resource "pie" at the village level, and benefit sharing potentially increases the share of that larger pie available to the community. In this section we summarize the key elements of both new policies and assess the opportunities and challenges they present for more effective poverty alleviation through use of forest resources.

Before describing the enabling legislation for community forestry, it is useful to define "community forestry" and to describe its development in Vietnam. Arnold (1992:25) defined community forestry as:

“... an umbrella term denoting a wide range of activities which link rural people with forests and trees, and the products and benefits to be derived from them. If there is one dimension to be stressed above all others it is the range and diversity of these linkages, and the span of different disciplines which are engaged in aspects of community forestry. Community forestry is, therefore, not a separate discipline, or even a programme, but one dimension of forestry, agriculture, rural energy and other components of rural development."

Gilmour and Fisher (1991) specify that community forestry involves control and management by rural people as an identifying characteristic.

In Vietnam, as in many countries, it is important to distinguish between traditional and introduced models of community forestry. Traditional community forestry is that which has been long practiced by rural communities without any encouragement or guidance by people or institutions from the outside. Introduced community forestry is that type of community forestry that is promoted in a given locality by outside agents (e.g., forestry extension personnel, members of environmental NGOs, etc.) 
as a solution to perceived socioeconomic and/or environmental problems at the local level. Specifying this difference in the context of the literature on Vietnam is important for two reasons. First, because authors tend to use the term "community forestry" in the sense of one or the other (or both) of these sub-types, but without being clear which they mean. Second, because at this historical juncture, the evolution of community forestry in Vietnam will likely mean some combination of both models in a given locality. A key issue in the implementation of community forestry will be how and to what extent the two models coincide.

It is useful to review why the two models are likely to be combined. Dating from before the 1960s, community-level management of forests and natural resources was common in the remote uplands. Beginning in the 1960s, centralized state control of forests was introduced. Through collectivization campaigns, cooperatives replaced existing communities, and indigenous norms disappeared in some locations. By excluding local residents from access to forest land in some cases, state policy was at odds with local management (Sikor and Apel 1998:2-4). Beginning in 1991-1993, strong state control of forests was rescinded, and the households were designated to replace State Forest Enterprises as the managers of natural forests (Sikor and Apel 1998:4). The new community forestry legislation indicates the willingness of the national government to "come full circle" and restore a degree of management initiative that used to reside largely-if not exclusively-in communities.

The revised Land Law that creates the legal basis for community forestry designates in its list of land users: "Residential communities including communities of Vietnamese residing in the same village, hamlet or similar residence with the same tradition, customs or in the same extended family, to which land is allocated or who are using land and have been acknowledged by the State with regard to their land use rights" (SRV 2003:7). This legislation is exceedingly important because forestry experts recognize that the biggest single obstacle to the development of community based forest management in Vietnam has been the lack of recognition of communities and their use-rights of forests and forest lands (Nguyen Hai Nam 2002:3).

The legislation on benefit sharing related to forests (known as Decision No. 178 of November 12, 2001) specifies the benefits from the sale of forest products to households and individuals to whom forest land has been allocated, leased, or contracted. Important in this legislation is that individuals and households will be able to get two-thirds or more of the total value of harvested products, including timber, with the remainder of the share going to the commune budget or other government entities (MARD 2003). This is a dramatic improvement over past arrangements, where the economic benefits to individuals and households were either non-existent, low, or poorly specified.

Policymakers must be mindful of potential problems in the implementation of this new legislation. First, it is possible that some communities will not be able to appropriately implement exogenous models of community forestry in areas where the process of collectivization has dismantled indigenous norms and systems of organization. Moreover, most ethnic minority communities have experienced in-migration from other ethnic minority groups and/or the Kinh, so various land management traditions may have to be taken into account in establishing community forestry. Powerful influences from outside the village have undermined local authority and have constrained the ability of villagers to manage forests effectively (Gilmour 1998:12-13). In areas where there are tense relations between state agencies and village residents because of past policies, it may be difficult to lay the groundwork 
for effective community forestry (Sikor and Apel 1998:18). Second, it is important to bear in mind that some aspects of community forestry might be inconsistent with the devolution of management responsibility to individual households (Gilmour 1998:4). Third, it is possible that some commercial forestry enterprises, which have a stake in maintaining their stream of benefits, may pose obstacles to the effective implementation of community forestry. Fourth, the closure of the extraction quotas for almost all SFEs has fueled illegal logging, which potentially undermines the revenue base for community forestry regimes. ${ }^{29}$ Fifth, it remains to be seen if the legislation on benefit sharing can be a useful instrument for developing community forestry; it must be effectively adapted to varying circumstances in different parts of the country (Vu Hoai Minh and Warfvinge 2002:12).

Yet in spite of these reasons for concern, there are some bases for optimism that the community forestry and benefit sharing legislation can assist forest-based poverty alleviation in Vietnam. First, at least on paper, the community forestry legislation offers real devolution to villages and hamlets, and the benefit sharing law offers substantial economic incentives for participating in community forestry. Real devolution of decision-making power to communities is the essential foundation for improving livelihoods through community forestry (Fisher 2003:18-19). Second, it appears that at least in some communities, the foundation for community forestry is strong in spite of past policy barriers. Case studies conducted in three provinces (Hoa Binh, Nghe An, and Thua Thien-Hue) show that communities have been able to circumvent formal restrictions and have implemented their own system of community forestry with or without external support (Vu Hoai Minh and Warfvinge 2002:3). The communities at these case study sites have been able to convince local authorities of the soundness of their approach (Vu Hoai Minh and Warfvinge 2002:47). The authors of the study claim there are hundreds of cases of this kind of management all over Vietnam (Vu Hoai Minh and Warfvinge 2002:45). The authors of another set of case studies on the feasibility of community forestry share this optimistic outlook, in spite of the relative lack of popular participation in Vietnam as compared to India, Nepal, Thailand, and other countries (Sikor and Apel 1998:2). Another set of case studies offers preliminary evidence that allocation of forests to communities can lead to improved local management of natural resources (Nguyen Hai Nam 2002:8). 


\section{Usefulness of forests for poverty alleviation in Vietnam: A synthesis}

We now attempt to address the three key questions posed at the outset with respect to the various modes of forest-based poverty alleviation (FBPA) examined above (see Table 1).

The following are aggregated answers to the three key questions:

\section{(1) Have forest resources in Vietnam served a useful role in poverty alleviation in the past?}

Clearly, forest resources have played an important role for millions of Vietnamese in assisting the process of poverty alleviation. We know this even in the absence of empirical data because increased per capita income has historically been tied to the transition from hunting and gathering to swidden and sedentary agriculture. This transition has in turn been related to permanent or temporary conversion of natural forests to other land uses. But beyond this, the situation is far less clear and much remains to be known. We know that the livelihood outcomes of increased agricultural commodity production and of forest land allocation have been uneven, but we do not know to what extent and why. We know very little about incomes from small-scale timber harvesting, most of which is probably illegal. We know that NTFPs are an important part of the income mix of millions of households, but we know little about the extent of their contribution and about the ways they may have served either as a safety net or as a poverty trap. We know that Forest Protection Contracts have shown a degree of success in some places but have failed in many others, and it is not clear what explains the difference. There is almost no available knowledge on the indirect contribution of forests to poverty alleviation. 
Table 1. Answers to three key questions in connection with modes and sub-modes of forest-based poverty alleviation (FBPA).

\begin{tabular}{|c|c|c|c|c|}
\hline \multicolumn{2}{|c|}{ Type of FBPA } & \multicolumn{2}{|c|}{$\begin{array}{c}\text { Usefulness of forests for poverty } \\
\text { alleviation }\end{array}$} & \multirow{2}{*}{$\begin{array}{l}\text { 3. Compatibility of } \\
\text { poverty alleviation } \\
\text { and reforestation }\end{array}$} \\
\hline Mode & Sub-mode & 1. In the past & $\begin{array}{l}\text { 2. In the } \\
\text { future }\end{array}$ & \\
\hline \multirow[t]{3}{*}{$\begin{array}{l}\text { Forest } \\
\text { conversion }\end{array}$} & $\begin{array}{l}\text { Swidden } \\
\text { cultivation }\end{array}$ & Highly useful & $\begin{array}{l}\text { Declining } \\
\text { usefulness }\end{array}$ & $\begin{array}{l}\text { Incompatibility } \\
\text { perhaps overstated }\end{array}$ \\
\hline & $\begin{array}{l}\text { Agricultural } \\
\text { commodities }\end{array}$ & $\begin{array}{l}\text { Uneven outcomes; } \\
\text { much is unknown }\end{array}$ & Unclear & $\begin{array}{l}\text { Probably negative, } \\
\text { but unclear }\end{array}$ \\
\hline & $\begin{array}{l}\text { Forest Land } \\
\text { Allocation }\end{array}$ & $\begin{array}{l}\text { Uneven outcomes; } \\
\text { much is unknown }\end{array}$ & Unclear & $\begin{array}{l}\text { Unclear (e.g., } \\
\text { differing views of } \\
\text { Sikor and Howard) }\end{array}$ \\
\hline \multirow[t]{2}{*}{ Timber } & $\begin{array}{l}\text { Small-scale } \\
\text { logging }\end{array}$ & $\begin{array}{l}\text { Unclear; much is } \\
\text { unknown }\end{array}$ & $\begin{array}{l}\text { Diminishing } \\
\text { over time }\end{array}$ & $\begin{array}{l}\text { Probably negative, } \\
\text { but unclear }\end{array}$ \\
\hline & $\begin{array}{l}\text { Small-scale } \\
\text { plantations }\end{array}$ & $\begin{array}{l}\text { Limited usefulness } \\
\text { because of over- } \\
\text { supply and low } \\
\text { prices }\end{array}$ & $\begin{array}{l}\text { Unclear to } \\
\text { what extent } \\
\text { planned } \\
\text { reforms can } \\
\text { overcome } \\
\text { problems }\end{array}$ & $\begin{array}{l}\text { Not clear has } \\
\text { significantly helped } \\
\text { to maintain forest } \\
\text { cover }\end{array}$ \\
\hline NTFPs & All types & $\begin{array}{l}\text { Clearly useful, but } \\
\text { unclear to what } \\
\text { extent and how }\end{array}$ & $\begin{array}{l}\text { Useful, but } \\
\text { sustainability } \\
\text { unclear }\end{array}$ & $\begin{array}{l}\text { Significant and } \\
\text { lasting NTFP } \\
\text { incomes may mean } \\
\text { less pressure on } \\
\text { forests }\end{array}$ \\
\hline \multirow[t]{2}{*}{$\begin{array}{l}\text { Payment } \\
\text { for } \\
\text { environ- } \\
\text { mental } \\
\text { services }\end{array}$} & $\begin{array}{l}\text { Forest } \\
\text { Protection } \\
\text { Contracts }\end{array}$ & $\begin{array}{l}\text { Isolated successful } \\
\text { cases, but many } \\
\text { disappointments; } \\
\text { low benefits to } \\
\text { households }\end{array}$ & $\begin{array}{l}\text { Unlikely; } \\
\text { depends on } \\
\text { reforms to } \\
\text { program }\end{array}$ & $\begin{array}{l}\text { Not clear has } \\
\text { significantly helped } \\
\text { to maintain forest } \\
\text { cover }\end{array}$ \\
\hline & ICDPs & $\begin{array}{l}\text { Low number of } \\
\text { beneficiaries; } \\
\text { probable low returns } \\
\text { to households, but } \\
\text { unclear }\end{array}$ & Unclear & Unclear \\
\hline $\begin{array}{l}\text { Employ- } \\
\text { ment }\end{array}$ & $\begin{array}{l}\text { Industrial } \\
\text { labor }\end{array}$ & $\begin{array}{l}\text { Unknown assistance } \\
\text { to poverty } \\
\text { alleviation; low } \\
\text { relevance because } \\
\text { of small numbers }\end{array}$ & $\begin{array}{l}\text { Will likely } \\
\text { not be an } \\
\text { important } \\
\text { route to } \\
\text { poverty } \\
\text { alleviation }\end{array}$ & Not relevant \\
\hline \multirow[t]{2}{*}{$\begin{array}{l}\text { Indirect } \\
\text { benefits }\end{array}$} & $\begin{array}{l}\text { Multiplier } \\
\text { effects }\end{array}$ & $\begin{array}{l}\text { Unclear; almost } \\
\text { no information } \\
\text { available }\end{array}$ & Unclear & Unclear \\
\hline & $\begin{array}{l}\text { Trickle } \\
\text { down }\end{array}$ & $\begin{array}{l}\text { Unclear; almost } \\
\text { no information } \\
\text { available }\end{array}$ & Unclear & Unclear \\
\hline
\end{tabular}




\section{(2) Can forest resources in Vietnam serve a useful role in poverty alleviation in the future?}

Almost undoubtedly, forest resources can continue to serve a useful role in poverty alleviation in the future. We can deduce this from the mere fact that millions of Vietnamese currently have forest resources at their disposal that they will continue to use. But the important issues are much more challenging and specific and go far beyond this general and rather bland observation. The capacity of forest resources in Vietnam to continue to support livelihoods depends critically on the lasting availability of those resources where no other alternatives exist. It also depends critically on how Vietnam negotiates the rapid transition from a natural-forest economy to a plantation economy. ${ }^{30}$ And it also depends on the capacity of the national, provincial, and district governments to adapt and improve programs that have a very uneven record to date (e.g., FLA and FPCs). We believe that, on the whole, a solid legal foundation for community forestry in Vietnam and effective implementation of the benefit sharing law can greatly improve the role of forests in reducing poverty in remote areas of Vietnam.

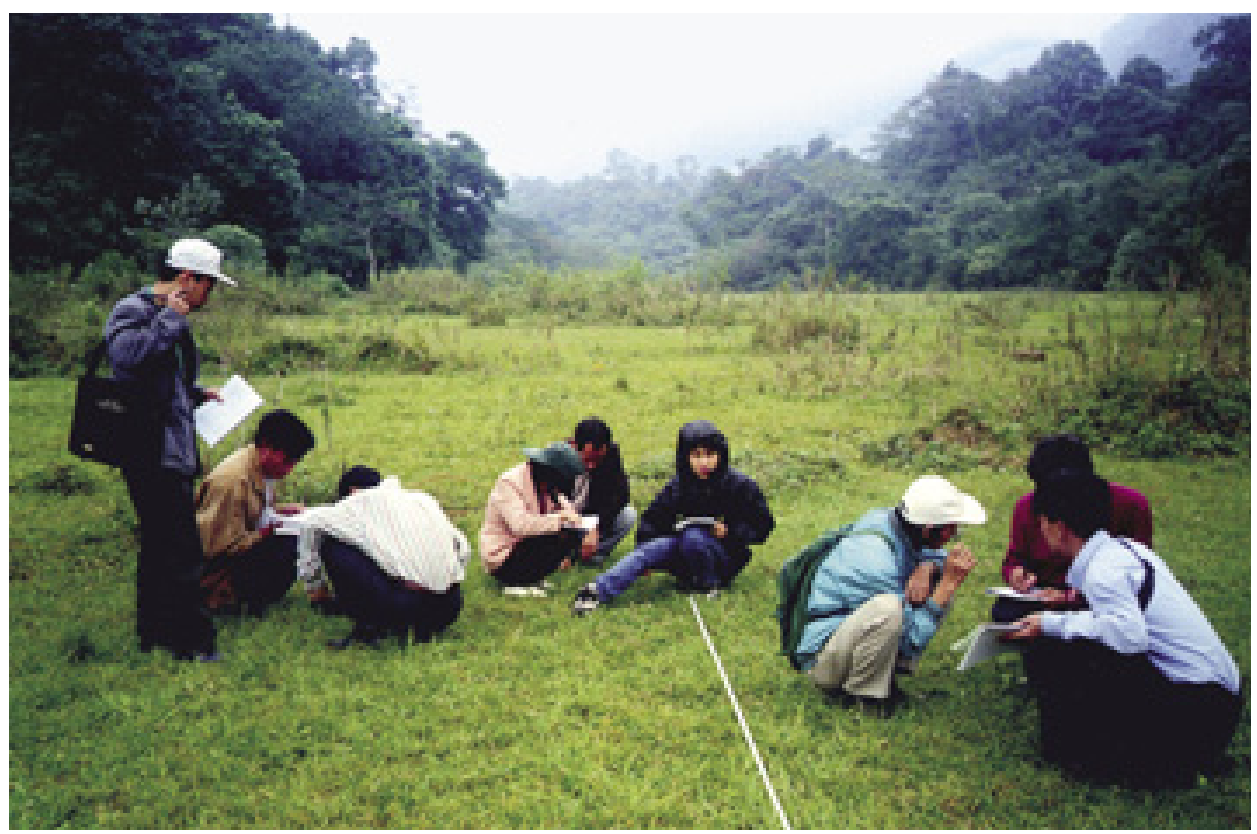

Researchers in the field (Photo by Andy Gillison)

\section{(3) To what extent are poverty alleviation and massive} reforestation through the 5 MHRP ultimately compatible?

It is as yet unclear to what extent forest-based poverty alleviation and massive reforestation either are or will be compatible goals. The key challenge to realizing this "win-win" outcome is that, logically, some continued progress in rural poverty alleviation will be tied to some degree of forest cover removal and forest degradation since the two have been linked historically. The recent history of forest cover change in Vietnam has been dominated by "win-lose" outcomes (people prosper at 
the expense of forest cover) and "lose-lose" outcomes (swidden cultivation under conditions of high population pressure).

One important issue is whether continued deforestation and forest degradation (i.e., that portion that is inevitable and justifiable from a livelihoods point of view) does or does not overlap with areas the government deems critical for meeting the environmental goals of the 5MHRP. The key opportunity and challenge is to devise livelihood opportunities on bare and degraded lands that are sufficiently attractive and durable to deter interest in ecologically destructive livelihoods. Effective implementation of community forestry will likely be key in providing such livelihood opportunities.

In order to better harmonize the goals of rural poverty alleviation and massive reforestation, it will be necessary to give attention to the following three questions: What land uses are poor people losing access to when plantations are established? What net incomes and other direct benefits will poor people receive from the plantations? And what indirect benefits will they receive through national and regional economic growth?

One key conclusion that surfaces from this study is that a great deal is unknown about the potential for using forests for poverty alleviation and about the compatibility of poverty alleviation and the reforestation goals of the 5MHRP. The literature simply does not reveal much of what needs to be known. This conclusion emerges clearly from the "mode-specific" observations in Table 1 and in the aggregated answers above. We believe that research must be carried out to fill in the information gaps in the literature.

A second key conclusion is that a comparative approach, based on primary field research, can produce answers to some of the most pressing outstanding questions. This can be deduced from the fact that there are successes and failures in both the FLA and FPC programs. Some of the outcome differences are likely traceable to policy, design, and implementation capacity variations among different provinces and districts. Other differences can be attributed to biophysical and locational circumstances. Contrasting the various local policy adaptations may well prove indispensable for proposing broad changes at the national level. Another area where a comparative research approach will be indispensable is to understand the wide variation in NTFP benefits, as well as various types of plantations schemes. What will be best for poverty alleviation: government schemes; industry-led outgrower schemes; or spontaneous tree planting by farmers? Research to address these questions should be complemented by financing of local pilot projects, capacity building, and investments to assure that new knowledge is put directly to use in poverty alleviation.

A third key conclusion is that knowledge at the boundary of poverty alleviation and forest resources would be greatly served by more systematic collaboration and planning between and among the relevant ministries, most notably the Ministry of Labor, Invalids and Social Affairs (with lead responsibility for poverty alleviation) and the Ministry of Agriculture and Rural Development (with lead responsibility for forestry and the 5MHRP), and the Ministry for Planning and Investment. It would also be important to improve collaboration within ministries, for example between the Forest Protection Department and the Forest Department within MARD. Perhaps most important of all is to assure fluid communication and harmonious collaboration between government entities at the national level and the local level, given the high level of initiative and responsibility shown by provincial governments in addressing poverty alleviation and forest management improvement. 


\section{Key research questions}

Here we list what we believe are some of the most important research questions on forests and poverty alleviation in Vietnam. While by no means an exhaustive list of the research needed, it is one effort to identify useful starting points.

\section{Shifting cultivation}

Does shifting cultivation serve a vital and potentially lasting livelihood support function in certain remote locations? If it does, should it be actively supported and/ or defended, and if so, how?

\section{Expanded agricultural commodity production}

How can the livelihood benefits from increased agricultural commodity production be stabilized so as to avoid repetition of what happened with coffee? In this regard, what are the implications of Vietnam's increased integration into the global economy?

\section{Forest Land Allocation (FLA)}

Has FLA been largely successful or unsuccessful in terms of its socioeconomic and environmental goals? What factors (e.g., policy, bioregional variations, etc.) explain the wide differences in outcomes? What policy changes can improve FLA on: (1) land that has already been allocated; and (2) on land yet to be allocated? To what extent can allocations of forest land to households and communities resolve the cultural and equity problems encountered in the past? 


\section{Livestock}

What segment of the rural population benefits most from the growth of the national cattle herd, and are there growing inequities? Does the growth of the livestock sector have major negative impacts on forest cover?

\section{Small-scale natural timber operations}

To what extent has small-scale logging been important for poverty alleviation, taking into account the recent factors propelling it such as extension of roads, diffusion of chain saws, etc.? If the contribution to poverty alleviation has been significant, can it become a long lasting, rather than just a transitory, source of income?

\section{Small-scale production of plantation timber}

How is it possible to resolve the locational circumstance that the poorest of the poor tend to live in remote regions away from the eastern coast (see Figure 1), yet large timber processing facilities tend to be located near big roads, and in the case of some planned plants (see Jaakko Pöyry 2001) near ocean ports? How reliable is the forecast of a booming future demand for plantation timber? What are the geographical differences within Vietnam of timber supply and demand? Is there any way to make the poor the prime beneficiaries of (presumed) future growth in timber demand by addressing the following existing issues: (1) the participation of the poor requires access to land; (2) the poor require income in the short term whereas timber has an extended gestation period; (3) the excess of intermediaries; and (4) illegal logging? How can small-scale producers be protected against apparently unpredictable swings in under- and over-supply of raw materials? How can the poor be the prime beneficiaries if Vietnam decides to move from short- to long-rotations of timber species because of the regional over-supply of pulp and paper?

\section{NTFPs}

In what ways and to what extent do specific types of NTFPs support livelihoods? What is the role of NTFPs in fulfilling household safety-net functions and seasonal gap filler functions? Do certain types of NTFPs end up functioning as "poverty traps" and therefore should be supplanted or supplemented with alternative livelihoods? To what extent can NTFPs support poverty elimination if their production is supported through improved marketing mechanisms? Do forests exist that should not be converted to other land uses because they provide a vital yet invisible socioeconomic function?

\section{Forest Protection Contracts (FPCs)}

Can the planned expansion of benefits through FPCs (i.e., larger share of forest products, awards to households and not just individuals, linking to community forestry, and credit provisions) improve substantially the livelihood benefits? Will this in turn support the goal of forest restoration? 


\section{Multiplier effects}

What are the local multiplier effects of forest sector activities on the composition and quality of livelihoods? This question has obvious relevance given the plan to introduce a series of value-added activities along the chain of production from farm to factory and from factory to consumers both within and outside of Vietnam.

\section{Trickle down effects}

To what extent do forestry activities contribute to the national treasury through taxation and duty collection, and to what extent does this, in turn, aid overall development efforts? Clear answers to this question can be very useful not only for anticipating the national effects of a rapidly growing plantation and wood-processing sector, but also for the purpose of directing revenues to where they can be most usefully spent.

\section{Community forestry and benefit sharing}

How well equipped are village-level institutions for implementing community forestry and benefit sharing, given not only the erosion of such institutions through the effects of past policies, but also the challenge of implementing (possibly) new models of forest management? Will there be a level playing field such that communities will not lose out in competition with outside commercial interests for access to forest resources? Generally speaking, there is a poor understanding of the relationship between community forestry and the potential for poverty alleviation in Vietnam (Nguyen Hai Nam 2002:2). 


\section{Summary and conclusions}

This literature review has sought to understand issues at the juncture of two important national priorities in Vietnam: efforts to eradicate poverty in this poor yet gradually prospering country; and efforts to arrest the disappearance and degradation of forests and to reforest massive areas of the countryside. Even though poverty alleviation and forest management have tended to be entirely separate spheres of monitoring, documentation, research, analysis, planning, and policy formulation and implementation, compelling reasons demand that they be brought closer together. The areas of high incidence of poverty and of remaining natural forest cover tend to overlap in the national landscape. Given this reality, it is impossible to contemplate successful poverty elimination without serious attention to forest sector issues. Many of the poor have long depended on forest resources and will continue to do so. And conversely, it is necessary to give much stronger attention to the specific mechanisms of rural livelihood improvement to attain the goals of the 5MHRP.

Our review has examined documents at the interface of these two spheres of knowledge to answer questions concerning: (1) the usefulness of forest resources for past poverty alleviation; (2) the utility of forest resources for future poverty alleviation; and (3) the degree of compatibility between poverty alleviation and plans for massive reforestation. We have formulated broad answers to these three questions. These broad answers have some utility as a point of departure for reflection, but their shallowness and lack of specificity is a reflection of the absence of information in the available literature for answering the questions in a satisfactory way.

Our three key conclusions follow from this finding. First, much additional research is required because of the lack of information available in existing data sources and literature. Second, comparative field research, focusing on a contrast of successes and failures of various forestry programs and on varying policy approaches among provinces and districts, would produce useful answers. Third, useful policy lessons 
would surface as a matter of course from closer collaboration among departments and agencies concerned with poverty alleviation and forest management. Key in this regard would be the Ministry of Labor, Invalids and Social Affairs, the Ministry of Agriculture and Rural Development, and the Ministry for Planning and Investment. We believe our list of research questions, each related to specific modes and submodes of forest-based poverty alleviation, should receive priority attention. 


\section{Endnotes}

1 The total poverty rate measures the fraction of people who are below the poverty line, that is, those who cannot afford the food and nonfood consumption basket needed to obtain 2,100 calories per day per person. The food poverty rate indicates the fraction of people unable to afford the food portion of this consumption basket (ADB et al. 2003:8). The General Statistics Office of Vietnam relies on both income and expenditure data to measure poverty, whereas the Ministry of Labour, Invalids and Social Affairs uses only income data. The 1993 and 1998 poverty rate data were derived from the Vietnam Living Standards Survey, using a sample of 4,800 and 6,000 households respectively, whereas the 2002 data were derived from the Vietnam Household Living Standards Survey using 30,000 households for expenditure data and 45,000 households for consumption data. For additional information on poverty measurement and targeting in Vietnam, see Beard and Agrawal (2001:3 \& 25) and ADB et al. (2003:7-9 \&111-115).

${ }^{2}$ An earlier assessment by the World Bank is somewhat different, claiming that household income grew by 60 percent in the period 1993-1998 and that these improvements are explained mainly by diversification of on-farm activities (World Bank in Vietnam 2000:viii).

${ }^{3}$ De Koninck (1999:12-16) says that the use of defoliants during the Vietnam war was one fundamental cause of forest destruction, but that this cause has been exaggerated by some observers (De Koninck 1999:12 \& 16).

${ }^{4}$ Ethnic minorities in Vietnam tend to have more forest land than non-minorities. In the northern regions of the country, ethnic minorities have on average one hectare of forest land, about 13 times more than the Kinh and the Chinese (ADB 2003:29 \& 40). In general in Vietnam, the poor are more likely than the rich to have forest land (ADB 2003: 39).

${ }^{5}$ For an interesting case study on this phenomenon in Vietnam, see Alther et al. (2002). They explain that "Proximity to roads and markets has a positive influence on the farm household economy. Farmers in accessible areas have wider possibilities 
for income generation than farmers in more isolated areas, and tend to be wealthier as a result" (Alther et al. 2002:144).

${ }^{6}$ Some low income people live in formerly forested areas, and some have always resided on non-forested landscapes. A map of poverty density (numbers of people in a given area) in Vietnam shows the opposite pattern to the one described above. The highest densities of poverty occur in urban and coastal areas (ADB 2003:11).

${ }^{7}$ We have deliberately renamed FAO's second mode "timber" from the original "wood products," and we have renamed the third mode "non-timber forest products (NTFPs)" from the original "non-wood forest products (NWFPs)." The reason is we believe fuelwood shares many of the pro-poor characteristics of other NTFPs.

${ }^{8}$ For example in 1998 the value of international export of forest products was over US\$7 billion in ASEAN alone (FAO 2001:123). This excludes the value of domestic trade in forest products.

${ }^{9}$ Watkin (1999) says 74,000 hectares of forest were cleared in Dak Lak province for coffee production. Roche and De Koninck (2001:10) say that coffee, among various commercial monocultures, had a strong role in deforestation in the Central Highlands. De Koninck (1999:81-82) documents the role of agricultural crop expansion (mainly coffee and cashew) in deforestation in Lam Dong province. Fortunel (2003:317) says that in southern Dak Lak the establishment of coffee plantations took place mainly at the expense of forest cover in spite of a 1997 ministerial decision stating that the plan to plant 40,000 hectares of coffee by 2001 should not damage the forest environment.

${ }^{10}$ Personal communications with Bao Huy, January 17, 2004, and with Thomas Sikor, March 27, 2004.

${ }_{11}$ Personal communication with Thomas Sikor, March 27, 2004.

12 For example in Dak Lak province, FLA recipients are allowed to use up to 20 percent of their allocated land for agriculture and other purposes, but this is not the declared provincial policy.

${ }^{13}$ Castella et al. (2002) document this phenomenon in Bac Kan province.

${ }^{14}$ Ten million Vietnamese dong is approximately US\$636 at the current exchange rate. US\$1 $=15,729$ VND.

${ }^{15}$ Personal communication from Ross Hughes, February 4, 2004.

16 Personal communication, Sheelagh O’Reilly, Local Government Capacity Building Adviser, Northern Mountain Poverty Reduction Project, Hanoi, Vietnam, April 17, 2002.

17 Personal communication from Ross Hughes, February 2, 2004.

${ }^{18}$ Personal communication from Ross Hughes, February 2, 2004.

19 These data may by now be rather dated.

20 Personal communication with Ross Hughes, February 2, 2004.

${ }^{21}$ Conducted through France's World Food Programme in Vietnam (PAM) provided aid in the forestry, irrigation, and health care sectors. PAM funded six forestry projects with a total budget of US\$120 million. The major forestry component of PAM was forest plantations. Initially the program focused on creating employment for SFEs and agricultural cooperatives. At a later stage, it channeled funds to the household level.

${ }^{22}$ Note that the enterprise provides no documentation for these claims.

${ }^{23}$ Personal communication with Ross Hughes, February 2, 2004.

${ }^{24}$ Often, the households only receive a small portion of this, due to "leakage" in the delivery of the funds. (Personal communication, Jill Blockhus, February 2, 2004.) 
${ }^{25}$ Personal communication with Nguyen Ngoc Lung, chairman of Vietnam Forestry Association, February 2002.

${ }^{26}$ Personal communication with Ross Hughes, February 2, 2004.

27 Unfortunately, this decision does not specify any regulations regarding the rights of local households to exploit and use NTFPs. This ambiguity is evident not just in $\mathrm{Ha}$ Giang, but also in other locations throughout the country.

28 The survey collected data on all establishments employing five or more people. Employees were defined as people under the control of, and paid by, the establishment. This definition therefore excluded home-workers, apprentices, and prisoners (GSO 1999).

${ }^{29}$ Personal communication from Ross Hughes, February 2, 2004.

${ }^{30}$ Although natural timber supplies may decline over time, in the long term the area of planted timber may increase as timber becomes scarcer in the region and Vietnam becomes a supplier. 


\section{References}

ADB. 2000. Study on the Policy and Institutional Framework for Forest Resources Management. Asian Development Bank. TA No. 3255 - VIE. Rome, Italy and Hanoi, Vietnam: Agriconsulting S.P.A.

ADB. 2001. Poverty Alleviation in Credit, Forestry and Sedentarization Programs. Sedentarization and Poverty Reduction Project. Hanoi, Vietnam: Asian Development Bank.

ADB et al. 2003. Vietnam Development Report 2004: Poverty. Joint Donor Report to the Vietnam Consultative Group Meeting. December 2-3. ADB, AusAID, DFID, GTZ, JICA, Save the Children UK, UNDP, and the World Bank. Hanoi, Vietnam.

Alther, Cyril, Jean-Christophe Castella, Paul Novosa, Elrick Rousseau, and Tran Trong Hieu. 2002. Impact of accessibility on the range of livelihood options available to farm household in mountainous areas of northern Viet Nam. In J.C. Castella and Dang Dinh Quang (eds.) Doi Moi in the Mountains: Land use changes and farmers' livelihood strategies in Bac Kan Province, Vietnam. Hanoi, Vietnam: The Agricultural Publishing House. pp. 121-146.

Angelsen, Arild and Sven Wunder. 2003. Exploring the Poverty-Forest Link: Key Concepts, Issues and Research Implications. CIFOR Occasional Paper No. 40. Bogor, Indonesia: Center for International Forestry Research.

Apel, Ulrich and Pham Van Viet. 1997. An Evaluation of the Forest Protection Contracts and Regulations and Chieng Dong Commune, Yen Chau District. Working Paper No 7. Community Forestry Unit, Social Forestry Development Project (SFDP) Song Da and Ministry of Agriculture and Rural Development (MARD)-GTZ-GFA. Hanoi, Vietnam.

Apel, Ulrich. 1997. The Potential of Natural Regeneration for Re-establishment and Restoration of Forests in the Song Da Watershed. Working Paper No 8. Community Forestry Unit, SFDP Song Da, MARD, GTZ-GFA. Vietnam: SFDP. 
Apel, Ulrich. 2000. Forest Protection Regulations as a Precondition for Natural Regeneration in the Song Da Watershed, Northwest Vietnam. Paper at the Workshop "Sustainable Rural Development in the Southeast Asian Mountainous Region" organized by European Committee (EC), SIDA, GTZ. Hanoi, Vietnam.

Arnold, J.E. Michael. 1992. Community Forestry: Ten Years in Review. Revised Edition. Community Forestry Note 7. Rome: Food and Agriculture Organization of the United Nations.

Arnold, J.E. Michael. 2001. Forestry, Poverty and Aid. CIFOR Occasional Paper No. 33. Bogor, Indonesia: Center for International Forestry Research.

Artemiev, Igor. 2003. State Forestry Enterprise Reform in Vietnam: Unlocking the potential for commercial wood growing. EASRD Technical Note. The World Bank.

Bao Huy. 2003. Participatory Technology Development (PTD) on Natural Forests Allocated to the M'Nong Ethnic Community. Social Forestry Support Program. Tay Nguyen University.

Beard, James and Nisha Agrawal. 2001. Localizing IDTs for Poverty Reduction in Vietnam: Eradicating Poverty and Hunger. Hanoi, Vietnam: World Bank Office in Vietnam.

Bellamy, Ruffus. 2000. Assessing Different Approaches to Forest Management in Vietnam. Ottawa, Canada: International Development Research Centre.

Bien Quang Tu. 2000. Market Analysis and Development, Phase Two and Three, Tua Chua District, Lai Chau Province. National Consultancy Report No. 10. Vietnam: SFDP Song Da.

Blazeby K., Le Nguyen Ngat, Do Quang Thai and Nguyen Quang Truong. 1999. An analysis of Wildlife Trade Dynamics Around the Pu Mat Nature Reserve. Vietnam: TRAFFIC Southeast Asia.

Byron, R. Neil and J.E. Michael Arnold. 1999. What futures for the people of the tropical forests? World Development 27(5):789-805.

Cao Thi Ly. 2001. Tim hieu Phuong thuc Su dung dat cua nguoi Mnong xa Eahuar, Buon Don, Dak Lak. (Land use patterns of Mnong Ethnic minorities in Eahuar, Buon Don, Daklak province.) Vietnam: Tay Nguyen University.

Carew-Reid, J., S. Poynton, Chu Tri Thang, Olivier Dubois, Mark Halle, Thor Larsen, Le Duc Trung, Le Thac Can, Nguyen Minh Tu, Dara O'Rouke and Vu Xuan Nguyen Hong. 1999. A Study on Aid to The Environment Sector in Vietnam. Hanoi, Vietnam: Ministry of Planning and Development, United Nations Development Programme.

Carr K. 1998. The Socio-Economic Effects of Privatizing Forest Land in Vietnam: A Case Study of Lang Beo Village. Canada: The Centre for Southeast Asian Research, UBC Canada.

Castella, Jean-Christophe, Stanislas Boissau, Nguyen Hai Thanh, and Paul Novosad. 2002. Impact of Forestland Allocation on Agriculture and Natural Resources Management in Bac Kan Province, Viet Nam. In J.C. Castella and Dang Dinh Quang (eds.) Doi Moi in the Mountains: Land use changes and farmers' livelihood strategies in Bac Kan Province, Vietnam. Hanoi, Vietnam: The Agricultural Publishing House. pp. 197-220.

Collins, N. Mark, Jeffrey A. Sayer, and Timothy C. Whitmore. 1991. The Conservation Atlas of Tropical Forests: Asia and the Pacific. New York: Simon \& Schuster. 
CRES and Ford Foundation. 1999. Proceedings of National Workshop: "Research on Sustainable Development in Mountainous regions in Vietnam." Vietnam: Agricultural Publishing House.

CRES. 1998. Socio-economic Study of Northern Mountainous Regions. Hanoi: CRES, Vietnam National University.

Dang Thi Hue. 2000. Nghien cuu Chuyen doi trong Co cau Su dung Dat rung tai Yen Bai, Vietnam. (Research on the Changes of Land Use Patterns in Yen Bai Province, Vietnam.) Vietnam: MARD.

Dao The Anh. 1999. Kinh Te Ho Nong Dan Mien Nui. (Economy-Farmer Households in Mountainous Regions.) A paper at the National Workshop on "Research on Sustainable Development in Mountainous regions in Vietnam." Hanoi, Vietnam: Agricultural Publishing House.

Dao Trong Hung. 1998. The Dan Lai Ethnic Minority and Natural Resource Use. In A. Terry Rambo, Le Trong Cuc, Dao Trong Hung, and Tran Duc Vien (eds.) People in a Park: The Human Ecology of the Dan Lai Ethnic Minority in The Pu Mat Nature Reserve, Nghe An province, Vietnam. Unpublished paper for the EastWest Center and the Center for Natural Resources and Environmental Studies. Hanoi, Vietnam. pp. 23-30.

Dau Thi Lien 1999. Tinh hinh Kinh te Xa hoi cua Phu nu Vung rung Ngap man ven Bien Tinh Ha Tinh- Huong Cai thien Doi song va Moi Truong. (Socioeconomic Situation of Women in Mangrove Areas in Ha tinh- Livelihood and Environmental Improvement.) Vietnam: MARD.

De Koninck, Rodolphe. 1999. Deforestation in Vietnam. Ottawa, Canada: International Development Research Centre.

DoDinh Sam. 1994. Shifting Cultivation in Vietnam: Its social, economic and environmental values relative to alternative land use. IIED Forestry and Land Use Series No 3. London, UK: International Institute for Environment and Development.

Do Nhuan. 1998. Tac dong cua Khuyen nong Khuyen nong doi voi Phat trien Trang trai Nong Lam Nghiep tai Mien nui va Trung Du. Cuc Khuyen nong Khuyen lam. (Impacts of Agricultural and Forestry Extension on Agricultural and Forest Farms in Mountainous Regions.) A paper at the National Workshop on "Chu Rung va Loi Ich Trong Kinh Doanh Trong Rung." (Forest Owners and Benefits in Forest Plantation.) Hanoi, Vietnam: MARD.

Doan Diem, 1998. Tang Cuong Giao Dat Lam nghiep va Khuyen Khich Trong Rung Tren Dat Duoc Giao. (Forestland Allocation and Incentives for Forest Plantations). A paper at the National Workshop on "Chu Rung va Loi Ich Trong Kinh Doanh Trong Rung". (Forest Owners and Benefits in Forest Plantations.) Hanoi, Vietnam: MARD.

Dollar, David and Jennie Litvack. 1998. Macroeconomic Reform and Poverty Reduction in Vietnam. In David Dollar, Paul Glewwe, and Jennie Litvack (eds.) Household Welfare and Vietnam's Transition. Washington, DC: The World Bank.

Donovan, Deanna, A. Terry Rambo, Jefferson Fox, Le Trong Cuc and Tran Duc Vien. 1997. Development Trends in Vietnam's Northern Mountain Region, Volume 1 and 2. Hanoi, Vietnam: EWC and CRES.

EIU. 2001. Country Profile 2001: Vietnam. London: The Economist Intelligence Unit.

FAO. 2003a. State of the World's Forests. Rome: Food and Agriculture Organization of the United Nations. 
FAO. 2003b. Forests and Poverty Alleviation, by William D. Sunderlin, Arild Angelsen and Sven Wunder. In State of the World's Forests 2003. Rome, Italy: Food and Agriculture Organization of the United Nations. pp. 61-73.

FAO and DFID. 2001. How Forests Can Reduce Poverty. Rome, Italy: Food and Agriculture Organization of the United Nations. London, UK: Department for International Development.

Fforde, Adam and Steve Sénèque. 1995. The Economy and the Countryside: The Relevance of Rural Development Policies. In Benedict J. Tria Kerkvliet and Doug J. Porter (eds.) Vietnam's Rural Transformation. Boulder, Colorado: Westview Press. pp. 97-138.

Fisher, Robert J. 2003. Innovations, Persistence and Change: Reflection on the State of Community Forestry. In RECOFTC and FAO (eds.) Community Forestry: Current innovations and experiences. CD-ROM. Bangkok, Thailand: RECOFTC and FAO. pp. 16-29.

Fortech, 1998. Program 327: Review for the Vietnam Rural Development Strategy. Prepared for the World Bank. Canberra: Fortech.

Fortunel, Frédéric. 2003. L'état, les paysanneries et les cultures commerciales pérennes dans les plateaux du Centre Viêt Nam, l'autochtonie en quête de territoires. Doctoral thesis. Université Toulouse 2, Toulouse, France.

Friederichsen, Jakob R. and Franz Heidhues. 2000. Assessment of Erosion Control in Farming Systems in North-West Vietnam: Result of an Interdisciplinary Study Project. Germany: University of Hohenheim, Special Research Program, Center for Tropical Agriculture.

FSIV. 2002a. Overview and Analysis of Policies and Legislation in Relation to Nontimber Forest Products in Vietnam. Project on Sustainable Utilization of NTFPs. Vietnam: FSIV and IUCN.

FSIV. 2002b. NTFP Sub-Sector Analysis. Project on Sustainable Utilization of NTFPs. Vietnam: FSIV and IUCN.

Gilmour, Don. 1998. Options and Approaches for Community Participation in the Management of Watershed/Forest Resources in Dak Lak Province. Consultancy report on behalf of Deutsche Gestellschaft fur Technische Zusammenarbeti (GTZ) and Mekong River Commission Secretariat.

Gilmour, Don A. and Robert J. Fisher. 1991. Villagers, Forests and Foresters: The Philosophy, Process and Practice of Community Forestry in Nepal. Kathmandu: Sahayogi Press.

Glewwe, Paul, Michele Gragnolati, and Hassan Zaman. 2002. Who Gained from Vietnam's Boom in the 1990s? Economic Development and Cultural Change 50(4):773-792.

GSO. 1999. Analyze the Results of the Industrial Survey of Vietnam in 1999. Project VIE/97/051. Hanoi: General Statistics Office of Vietnam. http://www.un.org.vn/ unido/gso/default.htm. Accessed June 11, 2004.

Gutman, Pablo. 2001. Forest Conservation and the Rural Poor: A Call to Broaden the Conservation Agenda. Washington, D.C.: WWF Macroeconomics Program Office.

Hainsworth, Geoffrey B. 1999. Localized Poverty Reduction In Viet Nam: Improving The Enabling Environment For Livelihood Enhancement in Rural Areas. Vancouver, B.C., Canada: Center for Southeast Asia Research, University of British Columbia. 
Hoang The Khang. 2000. Tinh hinh Su dung Tai nguyen Thien nhien tai Vung dem Phong Dien, Hue. (Natural Resource Use in the Buffer Zone of Phong Dien Nature Reserve, Hue Province.) Vietnam: National Institute of Agricultural Planning and Projection, MARD.

Hoang Van Lam. 2000. NTFP Use by The Three Ethnic Minorities: Macoong, Tri and Ruc in Phong Nha-Ke Bang (Quang Binh province). Vietnam: Center for Research and Development of Ethnic Medicinal Plants and LINC project. Vietnam: WWF Indochina Programme.

Hobley, Mary, Ram Sharma and Axel Bergman. 1998. From Protection to Protection through Production: A process for forest planning and management in Ha Giang and Yen Bai provinces. Draft report.

Howard, Caroline. 1998. Forestry Transition in Vietnam. Commonwealth Forestry Review 77(4):249-253.

Huynh Thu Ba. 1998. Human Migration and Resource Utilization. Vietnam: WWF Indochina Program.

Huynh Thu Ba et al. 2002a. Indigenous Peoples/Ethnic Minorities and Poverty Reduction in Vietnam. Manila, Philippines: Asian Development Bank.

Huynh Thu Ba et al. 2002b. People, Land and Resources Study. Vietnam: WWF Indochina Program.

ILO. 2001. Social and Labour Dimensions of the Forestry and Wood Industries on the Move. Geneva: International Labour Office.

Irvin, George. 1995. Assessing the Achievements of Doi Moi. The Journal of Development Studies 31(5):725-750.

Jaakko Pöyry. 2001. Study on the Development Potential of Vietnamese Wood Growing Sector. Final report, November 2001. Jakko Pöyry Consulting.

Jamieson, Neil L., Le Trong Cuc and A. Terry Rambo. 1998. The Development Crisis in Vietnam's Mountains. East-West Center Special Reports No. 6. Honolulu, Hawaii: East-West Center.

Johnston, Janine. 2001. Vietnam, Coffee Exports and the Environment. TED Cast Studies. Number 652. http://www.american.edu/TED/vietnam-coffee.htm. Accessed March 30, 2004.

Khong Trong Ham. 1998. Loi ich cua Cong ty va Loi ich cua Nhan dan trong Cong tac Trong rung va Kinh doanh Nguyen lieu Giay. (Benefits of the Vinh Phu Paper Mill and Local People in Forest Plantation and Paper Production.) Cong ty Nguyen lieu Giay Vinh Phu. A paper at the National Workshop on "Chu Rung va Loi Ich Trong Kinh Doanh Trong Rung.” (Forest Owners and Benefits in Forest Plantations.) Hanoi, Vietnam: MARD.

Khuong Ba Tuan. 1998. Cac giai phap khuyen khich chu rung trong rung sau khi giao dat lam nghiep tai Thanh Hoa. (Incentives for Forest Owners After Forest Land Allocation in Thanh Hoa Province.) Vietnam: Thanh Hoa Department of Agriculture and Rural Development.

Lang, Chris. 1996. Globalization of the Pulp and Paper Industry. Uruguay: World Rainforest Movement.

Lang, Chris. 2001. Deforestation in Vietnam, Laos and Cambodia. In D.K. Vajpeyi (ed.) Deforestation, Environment, and Sustainable Development: A Comparative Analysis. Westport, Connecticut and London: Praeger. pp. 111-137. 
Lang, Chris. 2002. The Pulp Invasion: The international pulp and paper industry in the Mekong Region. Uruguay: World Rainforest Movement.

Le Duy Nguyen. 1998. Mot so Y kien Dong gop ve Van de Chu Rung va Tang cuong Loi Ich cua Chu rung. (Forest Owners- Increasing Benefits for Forest Owners, Perspectives from Private Forest Plantation Enterprises.) Doanh nghiep Trong rung Tu nhan, Nghe An. A paper at the National Workshop on "Chu Rung va Loi Ich Trong Kinh Doanh Trong Rung". (Forest Owners and Benefits in Forest Plantations.) Hanoi, Vietnam: MARD.

Le Quang Minh. 1999. Kien Thuc Ban Dia cua Mot So Dan Toc Thieu So Trong Viec Quan Ly Su Dung Dat o Mien Nui A Luoi, Hue. (Indigenous Knowledge of Ethnic Groups in Land Use and Management in A Luoi, Hue Province.) A paper at the National Workshop on "Research on Sustainable Development in Mountainous regions in Vietnam." Hanoi, Vietnam: Agricultural Publishing House.

Le Thac Can, Dang Trung Thuan, and Tran Yen. 1993. ElA of Bai Bang Pulp and Paper factory. Hanoi: EIA Unit, National Research Programme on Environment.

Le Thi Ngan and Nguyen Thi Tho. 2000. Thuc trang Doi ngheo cua Nguoi Tay o Thon Dong Sung, Xa Dong Hung, huyen Luc Nam, Bac Giang. (Poverty Situation of Tay Ethnic Communities in Bac Giang.) Vietnam: Hanoi Agricultural University.

Le Thi Phi, Tong Van Chung and Le Bang Tam. 2003. Upland Livelihoods and Assistance. Unpublished manuscript.

Le Trong Cuc and A. Terry Rambo. 2001. Bright Peaks, Dark Valley: A Comparative Analysis Of Environmental And Social Conditions And Development Trends In Five Communities In Vietnam's Northern Mountain Region. Hanoi, Vietnam: EWC, Upland Working Group, CRES, Vietnam National University.

Le Trong Cuc et al. (eds). 1996. Red Books, Green Hills: The Impact of Economic Reform on Restoration Ecology in the Midlands of Northern Vietnam. Center for Natural Resources and Environmental Studies, Hanoi University; Southeast Asian Universities/Agroecosystem Network; East-West Center/Program on Environment; University of California at Berkeley.

Le Trong Cuc. 1997. In Deanna Donovan, A. Terry Rambo, Jefferson Fox, Le Trong Cuc and Tran Duc Vien (eds.) Development Trends in Vietnam's Northern Mountain Region. Volume 2: Case studies and lessons from Asia. Hanoi, Vietnam: National Political Publishing House. pp. 51-63.

Le Trong Trai, Dang Thang Long, Phan Thanh Ha and Le Ngoc Tuan. 2002. Study of Hunting and Collecting Practices of Local Communities Living in A Luoi and Phong Dien Districts of Thua Thien Hue Province in Central Vietnam. Central Annamite Initiative Report No. 7. Hanoi, Vietnam: WWF Indochina Programme.

Le Van Vien. 2000. Comparative Analysis of Agricultural and Forestry Development in Nghe An. Vietnam: MARD.

Lecup, I. and Bien Quang Tu. 2000. A Participatory Diagnosis of the Local Non-Timber Forest Products and their Market Environment in Two Communes, Tua Chua District, Lai Chau Province. Consultancy Report No. 23. Vietnam: SFDP Song Da, MARD, GTZ.

Luong Van Tien. 1998. Mot so Bien phap Khuyen khich Ho nong dan Mien nui Tham gia Trong rung va Quan ly Rung ben vung. (Incentives for Mountainous Farmers to Participate in Sustainable Forest Plantation and Management.) A paper at the National Workshop on "Chu Rung va Loi Ich Trong Kinh Doanh Trong Rung." (Forest Owners and Benefits in Forest Plantations.) Hanoi, Vietnam: MARD. 
MARD. 2001a. Country Economic Review. Hanoi, Vietnam: Political Publishing House.

MARD. 2001b. Five Million Hectare Reforestation Program Partnership. Synthesis Report. Hanoi, Vietnam: Ministry of Agriculture and Rural Development, International Cooperation Department.

MARD. 2002. Forestry Development Strategy Period 2001-2010. Translated by 5MHRP Partnership Secretariat. Vietnam: Ministry of Agriculture and Rural Development.

MARD. 2003. Joint circular No. 80/2003/TTLT/BNN-BTC of September 3, 2003 guiding the implementation of Decision No. 178/2001/QD-TTg OF November 12, 2001 by the Prime Minister on the benefits and obligations of households and individuals to which forest and forest land were allocated, leased or contracted. Hanoi, Vietnam.

MARD/DFD. 2001. National Five Million Hectare Reforestation Programme (19982010). Hanoi: Ministry of Agriculture and Rural Development, Department for Forestry Development.

MARD/ICD. 2001. Five Million Hectare Reforestation Program Partnership: Synthesis Report. Hanoi: Ministry of Agriculture and Rural Development, International Cooperation Department.

McElwee, Pamela. 2001. Fuelwood Harvesting and Use in Cam Xuyen District, Ha Tinh Province. Hanoi, Vietnam: Forest Science Institute of Vietnam, Non-Timber Forest Products Research Center.

Minot, Nicholas and Bob Baulch. 2002. The Spatial Distribution of Poverty in Vietnam and the Potential for Targeting. MSSD Discussion Paper No. 42. Washington D.C.: International Food Policy Research Institute.

Minot, N., B. Baulch, and M. Epprecht in collaboration with the Inter-Ministerial Poverty Mapping Task Force. 2003. Poverty and Inequality in Vietnam: Spatial Patterns and Geographic Determinants. Hanoi: International Food Policy Research Institute and Institute of Development Studies.

Morrison, Elaine and Olivier Dubois. 1998. Sustainable Livelihoods in Upland Vietnam: Land Allocation and Beyond. IIED Forestry and Land Use Series No 14. London, U.K.: International Institute for Environment and Development.

MRDP. 2000. Report of the Non Timber Forest Products Study Training and Commune Study in Ha Giang. Vietnam: Mountain Rural Development Program.

MRDP. 2001 'Diversity' - The Key to Quality Cattle Production in Ha Giang. A Synthesis Report on Indigenous Fodder Management in Meo Vac, Ha Giang. Vietnam: Mountain Rural Development Program.

Ngo Thi Minh Hang. 1996. A Cost-Benefit Analysis of Smallholder Investments in Reforestation. National Economic University. SIDA Project 1 VIE 62.9. Vietnam.

Ngo Thi Phuong Anh et al. 1999. Mot so Nhan thuc qua Chuong trinh Dinh canh Dinh cu cua nguoi Ca Tu tai Huong Nguyen, Huyen A Luoi, Tinh Thua Thien Hue. (Sedentarization of Ka Tu People in Huong Nguyen, A Luoi, Thua Thien Hue Province.) Hanoi, Vietnam: Hanoi Agricultural University.

Nguyen Hai Nam. 2002. Community Forestry and Poverty Alleviation in Vietnam. Paper presented at the International Workshop on Forestry and Poverty Alleviation in Laos PDR for Forestry Strategy 2020. December 17-18, 2002. Vientiane. 
Nguyen Ngoc Binh. 1998. Vien tro cua Chuong trinh Luong thuc The Gioi (PAM) cho Chuong trinh Trong rung tai Viet Nam. (PAM (World Food Programme) and Forest Plantations in Vietnam.) A paper presented at the National Workshop on "Chu Rung va Loi Ich Trong Kinh Doanh Trong Rung." (Forest Owners and Benefits in Forest Plantations.) Hanoi, Vietnam: MARD.

Nguyen Ngoc Lung. 2001. Report on Study on Community Forestry and Community Forestry Policy in the Northwest Areas. Vietnam: Ministry of Agriculture and Rural Development and GTZ.

Nguyen Quang Duc et al. 1996. Fuelwood, Women and the Future. Vietnam: Vinh Phu Forest Research Center.

Nguyen Quoc Dung and Vuong Duy Quang. 1999. Community Based Natural Resource Management in Hue and Quang Nam. Unpublished manuscript. Vietnam.

Nguyen Quoc Dung, 2002. Land Use and Allocation in Thua Thien Hue and Quang Nam. In Huynh Thu Ba et al. (eds.) People, Land and Resources Study. Vietnam: WWF Indochina Program. pp. 14-21

Nguyen Thi Cach. 1999. Nghien cuu Tinh hinh Tieu thu Luong thuc trong Mua mua va Mua Giap hat cua Dan toc Ktu, Huyen Nam Dong, Hue. (Food Consumption of the Ktu Ethnic Group in the Rainy Season in Nam Dong District, Hue Province.) Vietnam: Hanoi Agricultural University.

Nguyen Thi Thu. 1999. Tinh hinh Kinh te Xa hoi cua Nguoi Tay tai Bac Giang. (Socioeconomic Situation of the Tay Ethnic Minority in Bac Giang Province.) Hanoi, Vietnam: Hanoi Agricultural University.

Nguyen Tuong Van. 2002. Nghien cuu Bo sung Ve Khoan Bao ve Rung va Su dung Dat Lam nghiep. (Supplementary Research on Forest Protection Contracts and Forestry Land Use.) Vietnam: NIAPP, MARD.

Nguyen Van Dang (ed). 2001. Lam Nghiep Viet Nam (Vietnam Forestry) 1945-2000. Vietnam: Agricultural Publishing House.

Nguyen Van San and David Gilmour. 1999. Forest Rehabilitation Policy and Practice in Vietnam. Hanoi, Vietnam: IUCN.

Nguyen Van So. 2001. Community Forestry Program in Vietnam. HoChiMinh City, Vietnam: University of Agriculture and Forestry at Thu Duc.

Nguyen Van Thang. 1997. Danh gia cac Phuong thuc Quan ly va Trong Rung. (Assessments of Forest Plantation Methods.) Vietnam: MARD.

Nguyen Van Thang. 2001. Bao cao Ket qua Cong tac Tham gia Bao ve va Quan ly Rung tai Bac Thai. (Results of Forest Protection and Management in Bac Thai Province.) Vietnam: Bac Thai DARD.

Nguyen Van Tiem. 1998. Chu rung va Loi ich cua Chu rung trong Kinh Doanh trong Rung. (Forest Owners and Benefits in Forest Plantations.) A paper presented at the National Workshop on "Chu Rung va Loi Ich Trong Kinh Doanh Trong Rung." (Forest Owners and Benefits in Forest Plantations.) Hanoi, Vietnam: MARD.

Nguyen Xuan Thanh et al. 2000. Mot so Van de Giao dat Nong Lam nghiep choc ac Ho nong dan Nguoi San Diu, Ban Trai Cong, Xa Dong hung, Luc Nam, Bac Thai. (Issues Concerning Forestland Allocation To the San Diu Ethnic Minority Farmers in Bac Thai.) Hanoi: Hanoi Agriculture University.

NIAPP. 1999. Tong quan Viec Su dung Dat tai Mot so tinh Mien Nui Vietnam. (Overview on Land Use in Mountainous Regions of Vietnam.) Hanoi, Vietnam: National Institute of Agricultural Planning and Projection, MARD. 
Ogle, A.J., K.J. Blakeney and Hoang Loe. 1999. Evaluation of State Forest Enterprises. Draft final report. Hanoi, Vietnam: ADB Forestry Sector Project.

Oksanen, Tapani and Christian Mersmann. 2002. Forests in Poverty Reduction Strategies: An Assessment of PRSP Processes in Sub-Saharan Africa. Unpublished paper.

Oksanen, Tapani, Brita Pajari and Tomi Tuomasjukka (eds). 2003. Forests in Poverty Reduction Strategies: Capturing the Potential. EFI Proceedings No. 47. Joensuu, Finland: European Forestry Institute.

O'Reilly, Sheilagh. 2000. Joint Forest Management in Vietnam - A Concept with a Future? Paper at the Workshop on "Sustainable Rural Development in the Southeast Asian Mountainous Region." Hanoi, Vietnam: EC, SIDA and GTZ.

Pham Chi Thanh et al. 1999. Nghien cuu Phat trien Mot so Cay thuoc Tham gia Chuyen doi Co cau Cay trong o Huyen vung cao Sa Pa, Lao Cai. (Development of Medicinal Plants in Upland Districts of Sa Pa, Lao Cai Province.) Vietnam: Hanoi Agricultural University.

Pham Duc Tuan. 1999. Bao cao Nghien cuu ve Thuc trang Kinh te Xa hoi cua Mot xa Vung cao va Mot xa Vung thap tai Mien nui phia Bac. (A Comparative Study of the Socio-economic Situations of a Lowland Commune and an Upland Commune in the Northern Mountains.) Hanoi, Vietnam: Hanoi Agricultural University.

Pham Ngoc Due et al. 1999. Evaluation of the Participatory Land use Planning and Land Allocation Methodology at Communal Level Developed by SFDP Song Da. Vietnam: SFDP Song Da.

Pham Van Viet. 1998. The Community Forest Management Strategy of the SFDP Song Da. Hanoi, Vietnam: SFDP Song Da, MARD, GTZ-GFA.

Pham Thi Xuan Mai et al. 1999. Nghien cuu Tinh hinh Kinh te Xa hoi tai Luong Son, Hoa Binh. (Socio-Economic Situation in Luong Son, Hoa Binh Province.) Hanoi, Vietnam: Hanoi Agricultural University.

Phan Thi Anh Dao, Phan Nguyen Hong. 1997. Socio-economic Situation of Women in Coastal Mangroves: Livelihood and Environmental Improvement. Vietnam: CRES and Vietnam Women's Association, Action for Mangrove Reforestation (ACTMANG).

Phan Thu Huyen. 1998. Su dung Lam san Ngoai go cua Dong bao Jarai tai Daklak. (NTFP Usage of the Jarai Ethnic Group in Daklak Province.) Trung tam Nghien Cuu Nong Nghiep. Vietnam: MARD.

Poffenberger, Mark et al. 1998. Stewards of Vietnam's Upland Forests. Asia Forest Network and the Forest Inventory and Planning Institute, Research Network Report No 10.

Quy-Toan Do, Lakshmi lyer. 2002. Land Rights and Economic Development: Evidence from Vietnam. Mekong Info website: http: / /www.mekonginfo.org

Raintree J.B., Le Thi Phi and Nguyen Van Duong. 1999. Report on a Diagnostic Survey of Conservation Problems and Development Opportunities in Khang Ninh Commune in the Buffer Zone of Ba Be National Park. Project on Sustainable Utilization of NonTimber Forest Products. Hanoi, Vietnam: Forest Science Institute of Vietnam.

Rambo, A. Terry. 1997. Development Trends in Vietnam's Northern Region. In Deanna Donovan, A. Terry Rambo, Jefferson Fox, Le Trong Cuc and Tran Duc Vien (eds.) Development Trends in Vietnam's Northern Mountain Region. Volume 1: An Overview and Analysis. Hanoi, Vietnam: National Political Publishing House. pp. 1-52. 
Rambo, A. Terry, Le Trong Cuc, Dao Trong Hung, and Tran Duc Vien. 1998. People in a park: The human ecology of the Dan Lai ethnic minority in Pu Mat Nature Reserve, Nghe An Province, Vietnam. Unpublished paper for the East-West Center and the Center for Natural Resources and Environmental Studies. Hanoi, Vietnam.

Rhind, Jonathan and Susan Iremonger (Eds.). 1996. Tropical Moist Forests and Protected Areas: The digital files - Version 1. CD-ROM. United Kingdom: World Conservation Monitoring Centre. Bogor, Indonesia: Center for International Forestry Research.

Roche, Yann and Rodolphe De Koninck. 2001. Les enjeux de la déforestation au Vietnam. VertigO: La revue en sciences de l'environnement sur le WEB. 3(1):115. http://www.vertigo.uqam.ca/vol3no1/art3vol3n1/y_roche_r_de-koninck. html Accessed April 1, 2004.

Rosenthal, S.H. 1998. A Review of Nature Conservation in Vietnam. Draft background paper for the World Bank's preparation of a rural development strategy in Vietnam. Unpublished.

Sage, Nathan and Nguyen Cu. 2001. A Discussion Paper on Analysis of Constraints and Enabling Factors of Integrated Conservation and Development Project. Vietnam: CARE, SNV and WWF Indochina Program.

SAM Program. 2003. Feeding Large Ruminants, Sustaining Agriculture and Preserving Forests in Northern Vietnam Uplands. Compendium on "Success Stories from Mountainous Development in Vietnam." FAO, Hanoi, Vietnam. http://www. knowledgebank.irri.org/sam/sam/pdf/2003_iym_samlivestock_e.pdf Accessed December 9, 2004.

Scherr, Sarah J., Andy White and David Kaimowitz. 2002. Strategies to Improve Rural Livelihoods through Markets for Forest Products and Services. Washington, DC: Forest Trends.

Schmidt, Ralph, Joyce K. Berry and John C. Gordon (eds.). 1999. Forests to Fight Poverty: Creating National Strategies. New Haven and London: Yale University Press.

SFDP. 1994. Agro-Economic Farm Household Survey in the Song Da Watershed, North West Vietnam. Baseline Study No. 3. Vietnam: SFDP Song Da, MARD, and GTZ.

Shanks, Edwin. 2002. Agriculture and Forestry Extension and Sustainable Livelihoods in the Uplands. Vietnam: Swiss Agency for Development Cooperation.

Sikor, Thomas. 1998. Forest Policy Reform: From State to Household Forestry. In Mark Poffenberger (ed.) Stewards of Vietnam's Upland Forests. Research Network Report Number 10. Asian Forestry Network. pp. 118-38.

Sikor, Thomas. 2001. The Allocation of Forestry Land in Vietnam: Did it Cause the Expansion of Forests in the Northwest? Forest Policy and Economics 2:1-11.

Sikor, Thomas and Ulrich Apel. 1998. The Possibilities for Community Forestry in Vietnam. Asia Forest Network Working Paper Series. Santa Barbara, California, USA: Asia Forest Network.

Smith, Joyotee and Sarah J. Scherr. 2002. Forest Carbon and Local Livelihoods. Policy Report. Bogor, Indonesia: Center for International Forestry Research; Washington, D.C.: Forest Trends. 
Sowerwine Jennifer, Nguyen Huy Dzung and Mark Poffenberger 1998. Part IV: Ba Vi National Park and the Dzao. In Mark Poffenberger et al. (eds.) Stewards of Vietnam's Upland Forests. Asia Forest Network and the Forest Inventory and Planning Institute, Research Network Report No 10. pp. 73-84.

SRV. 2002. The Comprehensive Poverty Reduction and Growth Strategy. Hanoi: Socialist Republic of Vietnam.

SRV. 2003. Draft Law for National Assembly's Ratification: Law on Land. Hanoi: Socialist Republic of Vietnam.

Sunderlin, William D. 2003. Poverty Alleviation and Forest Conservation: A Proposed Conceptual Model. Unpublished manuscript.

Tessier, Olivier. 2002. World Bank Vietnam Forestry Sector Development Project: Initial Social Screening. Montpellier, France: Tercia Consultants.

Thanh Nhan. 1998. Lam Nghiep - Mot huong lam giau cua ho nong dan mien nui. (Forestry - A Way to Improve the Lives of Mountain People). Hanoi, Vietnam: Forestry Magazine, September edition, pp. 8-16.

To Dinh Mai. 2001. Case study: Forest Land Allocation in Thanh Hoa Province. Vietnam: MARD.

To Dinh Mai and Vu Huu Tuynh. 2000. Tong quan ve Chu rung va Loi ich cua Chu rung trong Kinh doanh Rung trong o Vietnam. (Overview of Benefits of Forest Owners and Forest Plantations in Vietnam.) Vu chinh sach NN va PTNT. Vietnam: MARD.

Tran Duc Vien. 1997. An Overview of the Provinces Covered by the Forestry Cooperation Programme. In Deanna Donovan, A. Terry Rambo, Jefferson Fox, Le Trong Cuc and Tran Duc Vien (eds.) Development Trends in Vietnam's Northern Mountain Region. Volume 2: Case studies and Lessons from Asia. Hanoi, Vietnam: National Political Publishing House. pp. 22-34

Tran Duc Vien. 1999. Cac To Chuc Xa Hoi va Quan Ly Tai Nguyen Thien Nhien cua Nguoi Tay, Ban Tat, Da Bac. Hoa Binh. (Social Organizations and Natural Resource Management of Tay Ethnic Group in Hoa Binh province.) A paper presented at the National Workshop on "Research on Sustainable Development in Mountainous Regions in Vietnam." Hanoi, Vietnam: Agricultural Publishing House.

Tran Huu Nghi, Ngoc Quang, Quoc Dung (eds). 1999. Lam Nghiep Dak Lak So 1. (Dak Lak Forestry). Chi cuc Phat trien Lam nghiep Daklak. Buon Ma Thuot, Daklak, Vietnam: Daklak Forest Development Department, MARD.

Tran Ngoc Thanh. 2000a. Forest Land Allocation: A Prerequisite for Community Forest Management. Paper presented at the Workshop on "Sustainable Rural Development in the Southeast Asian Mountainous Region.” Hanoi, Vietnam: EC, SIDA, GTZ.

Tran Ngoc Thanh. 2000b Forest Land Allocation In Dak Lak - A Learning Process. Vietnam: MRC/GTZ Sustainable Management of Resources in the Lower Mekong Basin Project, Dak Lak Office.

Tran Ngoc Thanh. 2001. Su Tham gia trong tien trinh quy hoach su dung dat, giao dat, giao rung va quan ly rung o Dak Phoi, Huyen Lak, Dak Lak. (Participation in Land Use zoning, Forestland Allocation and Management in Dak Phoi, Daklak.) Daklak, Vietnam: MRC/GTZ Sustainable Management of Resources in the Lower Mekong Basin Project. 
Tran Van Bang. 1999. NTFP Consumption and Contribution to Livelihood of Villagers in Easup, Daklak. Unpublished manuscript.

Tran Van Con and Nguyen Van Doan. 2000. Bao Cao Ket Qua Nghien Cuu Diem Quan Ly Rung Cong Dong Tai Xa Dak Tover, Huyen Chu Pah, Tinh Gia Lai. (Community Forestry in Dak Tover Commune, Chu Pah District, Gia Lai Province.) Pleiku, Vietnam: Tropical Forestry Centre.

Vo Quy. 1996. The Environmental Challenges of Vietnam's Development. Draft Report. Regional Seminar on Environmental Education, March 19-22, University of Hanoi. Hanoi, Vietnam: Center for Natural Resources and Environmental Studies.

Vu Hoai Minh and Hans Warfvinge. 2002. Issues in the Management of Natural Forests by Households and Local Communities of Three Provinces in Vietnam: Hoa Binh, Nghe An, and Thua Thien-Hue. Asia Forest Network Working Paper Series, Volume 5. Santa Barbara, California, USA: Asia Forest Network.

Vu Hoang Minh. 2002. An Evaluation of Forest Protection Contracts in Ha Giang Province. Vietnam: Ha giang DARD, MARD.

Vu Huu Tuynh. 2001. Analysis and Assessment of the Implementation of Forest Management Policy and Institution at 5 Provinces under the Vietnam Sweden Mountainous Rural Development Programme. Vietnam: MRDP and MARD.

Vu Long et al. 1996. Tham Gia Quan Ly Tai Nguyen Rung Duoi Hinh Thuc Khoan Quan Ly va Bao Ve Rung. (Forest Resource Management via Forest Allocation for Management and Protection.) Vietnam: MARD.

Vu Long. 1998. Thi truong Go nguyen lieu tai Nha may Giay Bai Bang (tinh Phu Tho). (Market for Timber as Paper Material at Bai Bang Mill, Phu Tho Province.) A paper presented at the National Workshop on "Chu Rung va Loi Ich Trong Kinh Doanh Trong Rung." (Forest Owners and Benefits in Forest Plantations.) Hanoi, Vietnam: MARD.

Vu Van Tuan et al. 1996. Mot so Anh huong sau Thi diem Giao dat Giao rung o xa Tu Ne Huyen Tan Lac va Xa Hang Kia, Pa Co Huyen Mai Chau Tinh Hoa Binh. (Impacts of Forestland Allocation in Two Pilot Areas of Tu Ne Commune, Tan Lac District, Hang Kia and Pa Co Communes, Mai Chau District, Hoa Binh Province.) Vietnam: MARD.

Vuong Duy Quang. 2002. Anh huong cua Chuong trinh 327 trong Doi song Kinh te Xa hoi tai Mien nui Phia Bac. (Impacts of Program 327 on the Socio-Economic Situation of Northern Mountainous Areas.) Vien Nghien cuu Xa hoi, Vietnam.

Watkin, H. 1999. Farming and Logging Cut Forests by Third in 15 Years. South China Morning Post. August 6.

WCED (World Commission on Environment and Development). 1987. Our Common Future. Oxford: Oxford University Press.

World Bank. 2001. World Development Report 2000/2001: Attacking Poverty. Oxford: Oxford University Press.

World Bank. 2002. Vietnam Environment Monitor 2002. Vietnam: The World Bank in Vietnam.

World Bank. 2003. World Development Report 2003: Sustainable Development in a Dynamic World: Transforming Institutions, Growth, and Quality of Life. New York: Oxford University Press. 
World Bank in Vietnam. 2000. Vietnam Development Report 2000: Attacking Poverty. Hanoi, Vietnam: The World Bank in Vietnam.

World Bank in Vietnam, Oxfam GB and DFID. 1999. Participatory Poverty Assessment Report. Hanoi, Vietnam: The World Bank in Vietnam.

Wunder, Sven. 2001. Poverty Alleviation and Tropical Forests-What Scope for Synergies? World Development 29: 1817-1833.

WWF. 2000. Hunting Practices of Local people Living near Phong Dien Nature Reserve. Vietnam: WWF Indochina Program. 
